Cesar Gomes Miguel

\title{
Evolução Estrutural e Paramétrica de Redes Neurais Dinâmicas em Vida Artificial
}

\author{
Dissertação apresentada à Escola Politécnica da \\ Universidade de São Paulo (EPUSP) como parte dos \\ requisitos para a obtenção do Título de Mestre em \\ Engenharia Elétrica.
}


Cesar Gomes Miguel

\section{Evolução Estrutural e Paramétrica de Redes Neurais Dinâmicas em Vida Artificial}

Dissertação apresentada à Escola Politécnica da Universidade de São Paulo (EPUSP) como parte dos requisitos para a obtenção do Título de Mestre em Engenharia Elétrica.

Área de concentração: Sistemas Eletrônicos

Orientador:

Prof. Dr. Marcio Lobo Netto 
Este exemplar foi revisado e alterado em relação à versão original, sob responsabilidade única do autor e com a anuência de seu orientador.

São Paulo, 16 de abril de 2009.

Assinatura do autor

Assinatura do orientador

Ficha Catalográfica

\section{Edição Revisada}

Miguel, Cesar Gomes

Evolução Estrutural e Paramétrica de Redes Neurais Dinâmicas em Vida Artificial/ C.G. Miguel. - ed. rev. - São Paulo, 2009.

$109 \mathrm{p}$.

Dissertação (Mestrado) — Escola Politécnica da Universidade de São Paulo. Departamento de Engenharia de Sistemas Eletrônicos.

1. Algoritmos Genéticos 2. Redes Neurais Artificiais 3. Aprendizado Computacional 4. Computação Adaptativa I. Universidade de São Paulo. Escola Politécnica. Departamento de Engenharia de Sistemas Eletrônicos. II. t 
Aos meus pais. 


\section{Agradecimentos}

Durante o mestrado, diversas idéias surgem, levando a incontáveis caminhos de investigação. Algumas destas idéias persistem por mais tempo enquanto outras são colocadas de lado, similar ao processo evolutivo. Mas nesta analogia, quem faz o papel da seleção natural são todas as pessoas envolvidas, seja direta ou indiretamente, na elaboração do trabalho. Por este motivo, seria impossível deixar de agradecer principalmente meu orientador, Prof. Dr. Marcio Lobo Netto, por ter me aceito como seu aluno e por seu entusiasmo em estudar e entender temas relacionados à vida e às ciências cognitivas. Outra grande personalidade, a quem também devo parte do meu trabalho, é o estimado Prof. Dr. Henrique Schützer Del Nero (In Memorian), que sempre incentivou e defendeu o pensamento crítico e a multidisciplinaridade no estudo da mente, sendo um pioneiro nesta área em nosso país.

Não poderia deixar de agradecer, também, a todos os colegas e amigos do Cognitio, com os quais aprendi muito em nossas reuniões, informais ou não, em particular, ao Marcos Cavalhieri e à Carolina Feher (ICB), pelas longas discussões sobre computação e vida artificial.

Também agradeço à Universidade de São Paulo, em particular ao Laboratório de Sistemas Integráveis da Escola Politécnica, pelo suporte e acomodação do nosso grupo e toda infraestrutura, técnica ou adminstrativa, oferecida.

Do lado não acadêmico, mas de suma importância, está o suporte permanente dos meus pais e familiares, a quem devo integralmente toda minha educação. Se não fosse por eles, não estaria escrevendo estas linhas hoje.

A todos, mais uma vez, meus sinceros agradecimentos. 
"If the brain were so simple we could understand it, we would be so simple we couldn't" 


\section{Resumo}

A evolução de redes neurais artificiais encontra aplicações em diversos campos na área de aprendizado de máquina, em particular, simulações de vida artificial onde uma população de indivíduos controlados por redes neurais se adaptam num ambiente virtual a fim de realizar uma determinada tarefa. Similar ao processo natural pelo qual o comportamento do organismo se modifica filogeneticamente através da complexificação do sistema nervoso, tais simulações oferecem uma nova abordagem sintética no estudo da inteligência, em contraposição aos métodos simbólicos tradicionais. Um recente método, conhecido por NEAT (NeuroEvolution of Augmenting Topologies), é capaz de obter os pesos e a própria topologia de rede neural utilizando algoritmos genéticos. A codificação utilizada pelo NEAT é flexível o suficiente para permitir evolução aberta e arquiteturas neurais arbitrárias. Este trabalho apresenta uma implementação do NEAT que pode ser utilizada em conjunto com um simulador de propósito geral, chamado Breve, formando uma plataforma para experimentos de vida artificial. A implementação proposta também estende o NEAT para lidar com redes neurais dinâmicas, onde o nível de ativação dos neurônios varia continuamente no tempo. Este novo modelo é comparado com o método tradicional numa tarefa clássica de controle não-supervisionado, mostrando um aumento de eficiência na busca pela solução do problema. Os resultados obtidos motivam o uso desta plataforma para experimentos de vida artificial, onde uma população de indivíduos interage continuamente com um ambiente dinâmico, se adaptando ao longo das gerações.

Palavras-chave: Algoritmos Genéticos, Redes Neurais Artificiais, Neuroevolução, Vida Artificial. 


\section{Abstract}

The evolution of artificial neural networks has a wide range of applicability in diverse areas in the field of machine learning, particularly, in artificial life simulations where a population of individuals, controlled by neural networks, adapts in a virtual environment in order to solve a given task. Resembling the natural process in which an organism's behavior is subjected to phylogenetic modifications through the complexification of the nervous system, such simulations offer a new synthetic approach in the investigation of intelligence, counter posing traditional symbolic methods. A recent method known as NEAT (NeuroEvolution of Augmenting Topologies), is able to obtain the synaptic weights and the topology with the aid of genetic algorithms. The encoding used by NEAT is flexible enough to allow for open-ended evolution and arbitrary neural architectures. This work presents a NEAT implementation especially suitable to be used with a general purpose simulator known as Breve, constituting a framework for artificial life experiments. The proposed implementation extends NEAT to include dynamical neuron models, where their inner state continuously varies over time. The new model is then compared to the traditional method in a classic unsupervised control benchmark task, showing an efficiency increase while solving the problem. The obtained results motivate the proposed framework for general experiments in artificial life, in which a population of individuals continuously interact with a dynamical environment, adapting through generations.

Keywords: Genetic Algorithms, Artificial Neural Networks, Neuroevolution, Artificial Life 


\section{Lista de Figuras}

2.1 Evolução do sistema nervoso. Adaptado de (DORUS et al., 2004, p. 1028). 22

2.2 Neurônio biológico e seu modelo matemático. . . . . . . . . . . . . . . . . . 24

2.3 Diferentes topologias de rede. . . . . . . . . . . . . . . 25

2.4 Ativação por camadas numa rede feedforward . . . . . . . . . . . . . . . 27

2.5 Ativação paralela numa rede recorrente. . . . . . . . . . . . . . . . 27

2.6 Representação matricial de uma rede neural. . . . . . . . . . . . . . . . . . 28

2.7 Representação do cromossomo. . . . . . . . . . . . . . . . . . . . 32

2.8 Representação do Algoritmo Genético Padrão. . . . . . . . . . . . . . . . . 33

2.9 Mapeamento do genótipo para o fenótipo. . . . . . . . . . . . 35

2.10 Recombinação por um único ponto. . . . . . . . . . . . . . . 36

2.11 Exemplo de mutação binária. . . . . . . . . . . . . . . . . 37

3.1 Exemplo de codificação neural direta. . . . . . . . . . . . . . . . . . . . 41

3.2 Exemplo de codificação neural matricial. . . . . . . . . . . . . . . . . . 41

3.3 O problema da permutação em redes feed-forwards. . . . . . . . . . . . . . 42

3.4 Exemplo de codificação genética no NEAT. . . . . . . . . . . . . . . . . 45

3.5 Exemplo de mutação estrutural. . . . . . . . . . . . . . . . . . . 46

3.6 Operador de recombinação. . . . . . . . . . . . . . . . . . . . 48

3.7 RNAs aleatórias na primeira geração. . . . . . . . . . . . . . . . . 50

3.8 Mínima topologia inicial possível. . . . . . . . . . . . . . . . . 50

4.1 Exemplo de veículos de Braitenberg (1984). . . . . . . . . . . . . . . 53

4.2 Ambiente de simulação em Robótica Evolutiva. Adaptado de (NOLFI; FLOREANO, 2000). . . . . . . . . . . . . . . 56 
4.3 Exemplo de genótipo (esquerda) e o fenótipo resultante (SIMS, 1994b). . . 57

4.4 Exemplo de criaturas obtidas para nadar (esquerda), caminhar (centro) e agarrar um cubo $($ SIMS, 1994a) . . . . . . . . . . . . . . . 58

4.5 Ambiente Polyworld (YAEGER, 1994) . . . . . . . . . . . . . . . . . 59

4.6 (a) Rede neural de um único indivíduo; (b) Modelo de neurônio utilizado no Geb (CHANNON; DAMPER, 1998) . . . . . . . . . . . . . . . . . 60

5.1 Tipos de articulações disponíveis no Breve, através do ODE, para corpos compostos de vários objetos. . . . . . . . . . . . . . . . . . . . . . . 64

5.2 Visualização de alguns experimentos realizados no Breve. . . . . . . . . . . 64

5.3 Simbad: Ambiente de simulação para robótica evolutiva (HUGUES; BREDECHE, 2006). . . . . . . . . . . . . . . . . . . . . 66 66

5.4 Diagrama de blocos para o NEAT-Python. . . . . . . . . . . . . . 67

5.5 Algoritmo Genético Seqüencial e Paralelo. . . . . . . . . . . . . . . . . . . 69

5.6 A integração do NEAT e Breve é feita na definição do experimento. . . . . 70

6.1 Funções booleanas OR e AND, representam conjuntos linearmente separáveis. 72

6.2 Exemplo de conjunto linearmente não-separável (esquerda) e a função XOR. 72

6.3 (a) Distribuição de espécies ao longo das gerações e (b) evolução do valor adaptativo do melhor indivíduo e da média da população. . . . . . . . . . . 74

6.4 Solução típica encontrada pelo NEAT (esquerda), comparada com a topologia ótima (direita) . . . . . . . . . . . . . . . . . . 74

6.5 Representação para o problema do pêndulo duplo. . . . . . . . . . . . . . 75

6.6 As diversas variações para o problema do pêndulo duplo. . . . . . . . . . . 76

6.7 Topologia mínima para o DPNV. . . . . . . . . . . . . . . 81

6.8 Variação do ângulo para os dois pêndulos. . . . . . . . . . . . . . . . 82

6.9 Ambiente para busca de alimento e desvio de toxinas. . . . . . . . . . . 83

6.10 Disposição de sensores para decteção de objetos. . . . . . . . . . . . . . . . 84

6.11 Neurônios efetores e atuadores. . . . . . . . . . . . . . . . 85

6.12 Atualização a cada passo de tempo. . . . . . . . . . . . . . . . 86 
6.13 (a) Valor adaptativo médio da população e (b) do melhor indivíduo. . . . . 87

6.14 Rede neural do animat (as conexões entre os sensores e os neurônios efetores não são mostradas) . . . . . . . . . . . . . . . . . . . . . . . . . . 88

6.15 Caminho percorrido pelo melhor animat durante seu tempo de vida (resultado após 50 gerações) . . . . . . . . . . . . . . . . . . . . . 88

6.16 Caminho percorrido pelo melhor animat num ambiente estruturado. . . . . 89 


\title{
Lista de Abreviaturas
}

\author{
RNA Rede Neural Artificial \\ AG Algoritmo Genético \\ IA Inteligência Artificial \\ VA Vida Artificial \\ NEAT NeuroEvolution of Augmenting Topologies \\ CTRNN Continuous-Time Recurrent Neural Networks
}




\section{Sumário}

1 Introdução 16

1.1 Motivação e Justificativa . . . . . . . . . . . . . . . . . . . . . . 17

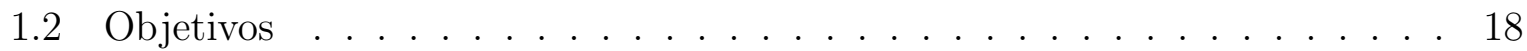

1.3 Metodologia . . . . . . . . . . . . . . . . . . . . . . . 19

1.4 Relevância . . . . . . . . . . . . . . . . . . . . . . . . . . 19

1.5 Organização do Texto . . . . . . . . . . . . . . . . . . 20

2 Fundamentos de Redes Neurais e Algoritmos Genéticos 21

2.1 Redes Neurais Artificiais . . . . . . . . . . . . . . . . . . . . 21

2.1.1 Motivação . . . . . . . . . . . . . . . . . . . . . . . 21

2.1.2 Breve Histórico das Redes Neurais . . . . . . . . . . . . . . . . 22

2.1 .3 O Neurônio Artificial . . . . . . . . . . . . . . . . . . . . 23

2.1.4 Topologias de Redes Neurais . . . . . . . . . . . . . . . . . 25

2.1.5 Redes Recorrentes de Tempo-Contínuo . . . . . . . . . . . . . 28

2.1.6 Modelos Neurais Pulsados . . . . . . . . . . . . . . . . . 30

2.2 Evolução e Algoritmos Genéticos . . . . . . . . . . . . . . . . . . 30

2.2.1 Complexidade e Emergência . . . . . . . . . . . . . . . . 30

2.2.2 Evolução . . . . . . . . . . . . . . . . . . . . . . 31

2.2.3 Principais Conceitos de AGs . . . . . . . . . . . . . . . 32

2.2.4 Modelo Básico de Algoritmo Genético . . . . . . . . . . . . . . . . 32

2.2 .5 Codificação . . . . . . . . . . . . . . . . . 34

2.2.6 Operadores Genéticos . . . . . . . . . . . . . . . 36 
2.2.7 Especiação . . . . . . . . . . . . . . . . . . . . . 37

3 Neuroevolução $\quad 39$

3.1 Codificação Genética de Redes Neurais . . . . . . . . . . . . . . . . . . . . 39

3.1 .1 Codificação Direta . . . . . . . . . . . . . . . . . . . . 40

3.1.2 O Problema da Permutação . . . . . . . . . . . . . . . . . . . . . . 41

3.2 Tipos de Neuroevolução . . . . . . . . . . . . . . . . . . . . . . . . 43

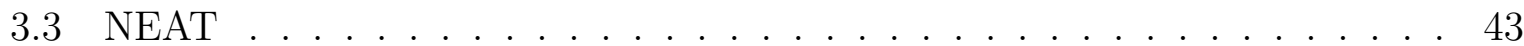

3.3 .1 Codificação Genética . . . . . . . . . . . . . . . . . . . . . . . 44

3.3 .2 Operadores Genéticos . . . . . . . . . . . . . . . . . 45

3.3 .3 Especiação . . . . . . . . . . . . . . . . . . . . 47

3.3 .4 Método de Seleção . . . . . . . . . . . . . . . . . . . . . . . . . . 49

3.3.5 Complexificação . . . . . . . . . . . . . . . . . . . . . . . . 49

3.4 Observações Finais . . . . . . . . . . . . . . . . . . . . . . 50

4 Neuroevolução em Vida Artificial 52

4.1 Histórico . . . . . . . . . . . . . . . . . . . . . . . . . 52

4.1.1 Veículos de Braitenberg . . . . . . . . . . . . . . . 53

4.1 .2 Abordagem Animat . . . . . . . . . . . . . . . . . . . 54

4.1.3 Robótica Evolutiva . . . . . . . . . . . . . . . . 55

4.2 Trabalhos Anteriores de Vida Artificial . . . . . . . . . . . . . . . 56

4.2 .1 Evolução Morfológica . . . . . . . . . . . . . . . . 56

4.2 .2 Polyworld . . . . . . . . . . . . . . . . . . . . 58

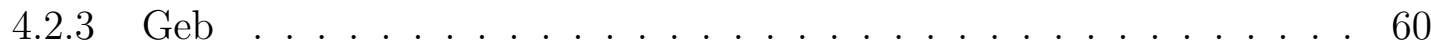

4.3 Conclusão . . . . . . . . . . . . . . . . . . . . . . . . . 61

5 Simuladores e Implementação $\quad 62$

5.1 Simuladores de Ambientes Virtuais . . . . . . . . . . . . . . . . 62 


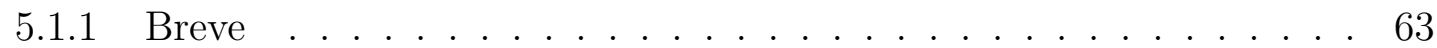

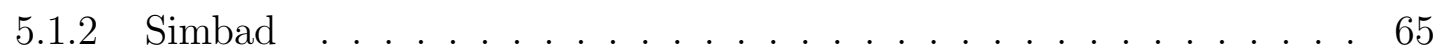

5.2 Simulador de Neuroevolução: Projeto NEAT-Python . . . . . . . . . . . . 66

5.2 .1 Módulo de Redes Neurais . . . . . . . . . . . . . . . . . . . . 68

5.2 .2 Execução Paralela . . . . . . . . . . . . . . . . . . . . . 68

5.2 .3 Integração com o Breve . . . . . . . . . . . . . . . . . . . . . . 69

5.3 Observações Finais . . . . . . . . . . . . . . . . . . . . . . . 70

$\begin{array}{llr}6 & \text { Experimentos } & 71\end{array}$

6.1 Ou-Exclusivo . . . . . . . . . . . . . . . . . 71

6.1 .1 Descrição do Problema . . . . . . . . . . . . . . . . . . . . 71

6.1 .2 Metodologia . . . . . . . . . . . . . . . . 72

6.1.3 Resultados e Discussão . . . . . . . . . . . . . . . . . . . . . . 73

6.2 Pêndulo Invertido . . . . . . . . . . . . . . . . . . . . . . 75

6.2.1 Descrição do Problema . . . . . . . . . . . . . . . . . . . 75

6.2 .2 Metodologia . . . . . . . . . . . . . . . . 77

6.2.3 Resultados e Discussão . . . . . . . . . . . . . . . . . . . . . . 79

6.3 Busca de Alimento . . . . . . . . . . . . . . . . . . . . . . 82

6.3.1 Descrição do Problema . . . . . . . . . . . . . . . . . . . . . . 83

6.3.2 Metodologia ........................ 85

6.3.3 Resultados e Discussão . . . . . . . . . . . . . . . . . . . 86

$\begin{array}{lll}7 & \text { Observações Finais } & 91\end{array}$

7.1 Limitações e Dificuldades . . . . . . . . . . . . . . . . . . . . . . . 91

7.2 Contribuições . . . . . . . . . . . . . . . . . . . . . . 92

7.3 Trabalhos Futuros . . . . . . . . . . . . . . . . . . 93

7.3.1 Codificação Genética Indireta . . . . . . . . . . . . . . . . . 93

7.3.2 Redes Neurais Pulsadas . . . . . . . . . . . . . . . . . . 94 
7.4 Considerações Finais . . . . . . . . . . . . . . . . . . . . 95

$\begin{array}{ll}\text { Referências } & 97\end{array}$

Apêndice A - Descrição dos parâmetros usados no NEAT-Python 104

Apêndice B - Configuração dos experimentos 107 


\section{Introdução}

Em Vida Artificial procuramos simular processos naturais com o intuito de estudar e compreender algumas características dos organismos vivos, como aprendizado ou inteligência. Portanto, seguindo uma abordagem evolutiva, a preocupação científica recai em obter modelos a partir de observações, onde tentamos corroborá-los através de simulações computacionais e, sempre que possível, fornecer um amparo matemático, permitindo fazer previsões e afirmações sobre seu comportamento qualitativo a longo prazo.

Neste sentido, redes neurais artificiais podem ser usadas como modelo do sistema nervoso, responsável pelo comportamento de organismos artificiais. Também é possível fazer com que uma população destes organismos passe por um processo evolutivo, onde os indivíduos mais adaptados ao ambiente artificial possam de alguma forma se reproduzir e gerar descendentes, carregando algumas de suas características para a próxima geração. Repetindo este processo por muitas vezes, espera-se que na média a população de indivíduos seja capaz de "sobreviver" às exigências impostas pelo ambiente, encontrando estratégias de comportamento capazes de aumentar suas chances reprodutivas.

Neste ponto surgem duas preocupações. A primeira diz respeito ao modelo biológico, isto é, como representar seu sistema nervoso, sensório e motor. A segunda situação leva em consideração o uso de um ambiente virtual, com o qual os indivíduos interagem. É importante criar um balanço entre os dois lados, de forma que o ambiente não seja altamente complexo a ponto de não permitir a adaptação da população e, de maneira similar, que os indivíduos não sejam tão simples que não possam se adaptar ao longo das gerações.

Num ambiente artificial onde toda a dinâmica é conhecida e controlada pelo experimentador, podemos nos preocupar principalmente com o tipo de indivíduo (também chamado de agente $^{1}$ ) que irá explorar este ambiente. Embora estes detalhes variem

\footnotetext{
${ }^{1}$ Existem diversas definições formais para diferentes contextos de agentes (NEVES, 2003, p. 54). Neste trabalho é suficiente considerar o agente como qualquer tipo de organismo.
} 
conforme o experimento, as características gerais são as mesmas. Resta-nos então nos concentrar na definição da forma de interação dessa população de indivíduos com o ambiente, através de seus sensores e atuadores, bem como na modelagem do processo evolucionário através do qual a população de indivíduos se adapta.

Este trabalho propõe investigar e implementar um modelo particular de neuroevolução conhecido por NEAT (NeuroEvolution of Augmenting Topologies), desenvolvido por Stanley (2004). O NEAT é capaz de adaptar, usando princípios de computação evolutiva, os ganhos sinápticos e a própria topologia da rede neural. Métodos de neuroevolução podem competir, em alguns casos, com as técnicas tradicionais de aprendizado supervisionado em redes neurais, como o algoritmo de retropropagação de erro (GUPTA; SEXTON, 1999; SIDDIQUE; TOKHI, 2001), e também podem substituir técnicas de caráter genérico de aprendizado por reforço em domínios não-supervisionados (GOMEZ, 2003; STANLEY; MiIKKULAIEN, 2002). Além do vasto campo de aplicações em áreas da ciência da computação, como IA e otimização, o principal enfoque neste trabalho será utilizá-lo simplesmente como um modelo simplificado da evolução natural, em particular, do sistema nervoso, seguindo metodologias já estabelecidas e propostas por diversos autores (VAARIO, 1994; NOLFI; PARISI, 2003; FRITZSCH, 2003; PFEIFER; SCHEIER, 1999).

\subsection{Motivação e Justificativa}

Dyer (1994) propôs um conjunto de problemas em aberto em Vida Artificial, dentre os quais a necessidade de estabelecer um processo evolutivo pelo qual pudéssemos obter arquiteturas de redes neurais somente com a interação de uma população de indivíduos com seu ambiente. Desta forma teríamos a possibilidade de observar, através de simulações, a emergência de comportamento adaptativo, possivelmente colaborando com o avanço da biologia em questões de "como a vida poderia ser" ${ }^{2}$ caso as condições iniciais fossem diferentes, ou mais especificamente, como as primeiras formas primitivas de inteligência poderiam ter surgido em certas ocasiões.

Organismos vivos apresentam um nível de robustez e autonomia ainda muito superior àquilo que conseguimos obter artificialmente. Entretanto, já ultrapassamos a capacidade humana média em tarefas bem específicas como jogar xadrez ou resolver problemas simbólicos (CAMPBELL; HOANE; HSU, 2002; NEWELL; SHAW; SIMON, 1960). As tentativas de reproduzir comportamento inteligente através de abordagens top-down mostram uma enorme falta de flexibilidade, inerentes aos sistemas baseados em lógica. Explorar todas

\footnotetext{
${ }^{2}$ Do inglês: life-as-it-could-be.
} 
as possibilidades existentes da interação de um agente com seu ambiente torna a tarefa intratável muitas vezes, acentuando-se em ambientes dinâmicos.

Por outro lado, a observação de formas de vida mais simples exibem uma enorme variedade de comportamentos, que provavelmente sejam mais suscetíveis de replicação através de simulações do que a tentativa de analisar e reproduzir o raciocínio humano por introspecção. Do ponto de vista natural, a inteligência não deve ser considerada como característica principal de um organismo, mas como uma capacidade adquirida gradualmente ao longo do processo evolutivo. A visão darwiniana da inteligência nos permite abranger as definições usuais e passamos então a nos preocupar com o comportamento do organismo como característica adaptativa que garante sua sobrevivência e reprodução no ambiente (PFEIFER; SCHEIER, 1999; STEELS, 1994).

A abordagem que segue a linha "do mais simples para o mais complexo" é o principal enfoque em Vida Artificial, a qual se baseia fortemente na biologia evolutiva, considerando esta como talvez a melhor fonte de inspiração para obtermos comportamentos que se assemelhem àqueles reconhecidos como inteligentes e observados na natureza. No lugar de tentarmos entender diretamente o resultado da evolução, poderíamos simular o próprio processo e estudar os resultados de cada etapa. O principal foco deste trabalho não é apresentar uma solução definitiva para um dos problemas apresentados por Dyer, mas fornecer uma contribuição neste sentido.

\subsection{Objetivos}

O propósito geral deste trabalho está em demonstrar a aplicação de um recente método de neuroevolução capaz de ajustar não só os ganhos sinápticos de uma rede neural mas também sua topologia. Este método será estendido para redes neurais de tempo contínuo, controlando o comportamento de organismos artificiais num mundo virtual, modelado em um ambiente de simulação de código aberto (open source), o Breve. Para tanto, o trabalho passará pelas seguintes etapas:

- Levantamento histórico e introdução teórica às áreas de RNAs e AGs;

- Identificação e proposição de métodos para configuração e otimização de RNAs com aplicação de AGs;

- Análise do NEAT, como método de neuroevolução; 
- Desenvolvimento de uma biblioteca implementando o NEAT, permitindo o uso de outros modelos neurais;

- Análise de simuladores para ambientes virtuais, com enfoque em VA;

- Realização de experimentos gerais envolvendo o NEAT;

- Avaliação dos resultados obtidos.

\section{$1.3 \quad$ Metodologia}

Este trabalho se baseia principalmente em publicações recentes no campo de Neuroevolução e Vida Artificial, além da literatura fundamental disponível em livros ou revistas na área de RNAs e AGs.

Um dos pontos principais no desenvolvimento da dissertação está na implementação de um método de neuroevolução chamado NEAT (STANLEY, 2004). A implementação será feita em Python (pela flexibilidade do uso de orientação a objetos e programação procedimental). O simulador Breve (KLEIN, 2002) será usado como ambiente virtual, onde será realizada parte dos experimentos. O simulador foi escrito em $\mathrm{C}++$, usando recursos gráficos em OpenGL. Todas as ferramentas utilizadas são de código aberto e desenvolvidas em plataformas GNU/Linux.

\subsection{Relevância}

Em Vida Artificial, o problema da inteligência é abordado do ponto de vista evolutivo, que pode ser explicado pelo resultado da interação do organismo com seu ambiente. Essa dinâmica é responsável pela diversidade de comportamentos existentes na natureza, dentre os quais alguns se destacam por suas vantagens em relação a outros.

Diversos modelos computacionais procuram simular o modo pelo qual o sistema nervoso de um organismo simples poderia sofrer alteração em resposta à adaptação evolutiva por seleção natural. Embora a natureza tenha encontrado formas de solucionar diversos problemas como armazenamento e transmissão de informação, codificação e regras de desenvolvimento, dentre outros, ainda estamos distantes de um modelo capaz de representar satisfatoriamente até mesmo uma parte destes mecanismos (ADAMI, 1998).

O NEAT, embora inspirado em conceitos da biologia, surgiu como um método de propósito genérico na comunidade de Redes Neurais Artificiais e Computação Evolutiva. 
Por ser recente ainda tem sido pouco explorado no contexto de vida artificial, permitindo diversas possibilidades no seu uso em experimentos de comportamento adaptativo.

\subsection{Organização do Texto}

Esse trabalho está dividido da seguinte forma: Introdução (Capítulo 1), Fundamentos de RNAs e AGs (Capítulo 2), Neuroevolução (Capítulo 3), Neuroevolução em Vida Artificial (Capítulo 4), Simuladores e Implementação (Capítulo 5), Experimentos (Capítulo 6), Conclusão e Trabalhos Futuros (Capítulo 7). O levantamento bibliográfico da teoria fundamental de Redes Neurais Artificiais e Algoritmos Genéticos, com enfoque para aplicações em Vida Artificial, é feito no Capítulo 2. No Capítulo 3 são descritos alguns conceitos de Neuroevolução, além do NEAT, principal método do trabalho. No Capítulo 4 é apresentada a revisão dos principais trabalhos envolvendo neuroevolução em vida artificial. O Capítulo 5 analisa dois principais simuladores disponíveis sob código aberto, incluindo o Breve, e apresenta o projeto de implementação da biblioteca para o NEAT. O Capítulo 6 descreve a realização de diversos experimentos fazendo uso dos conceitos anteriores. Por último, no Capítulo 7 serão apresentadas as conclusões e feitas algumas considerações, apontando para trabalhos futuros. 


\section{Fundamentos de Redes Neurais e Algoritmos Genéticos}

Neste capítulo são descritos os principais modelos de redes neurais artificiais relevantes para o trabalho, assim como os pontos de maior interesse na teoria de algoritmos genéticos.

\subsection{Redes Neurais Artificiais}

Esta seção descreve os principais pontos na teoria de redes neurais artificiais, partindo da motivação inicial que levou aos primeiros modelos, até novas formulações que incorporam maiores detalhes biológicos. Esse texto apresenta arquiteturas que podem ser utilizadas em experimentos de vida artificial, e portanto difere um pouco da abordagem tradicional apresentada em livros de redes neurais.

\subsubsection{Motivação}

O surgimento de células nervosas, capazes de transmitir informação a longas distâncias, teve um papel fundamental na adaptação de organismos multicelulares. A forma como estas células, ou neurônios, se interligam entre si e à periferia sensória e motora dá aos organismos a capacidade de interagir com seu ambiente, conferindo diversos níveis de comportamentos, como fugir na presença de um predador ou buscar alimento.

A organização do sistema nervoso difere entre as espécies, embora compartilhem características semelhantes como mostra a Figura 2.1, o que sugere um ancestral comum entre as espécies, tanto no nível genético como fenotípico (CZIKO, 1995). A evolução do sistema nervoso é responsável pelo surgimento do que intuitivamente denominamos inteligência (CZIKO, 1995; CAMPOS; SANTOS; XAVIER, 1997; CALVIN, 1998; RIBAS, 2006). Tentativas de compreender e reproduzir artificialmente o funcionamento do cérebro nos levou a propor modelos neurais baseados em observações empíricas, onde primeiramente procurou-se identificar a estrutura dos diferentes tipos de neurônios existentes e como 
estes são conectados entre si (ARBID, 2002).

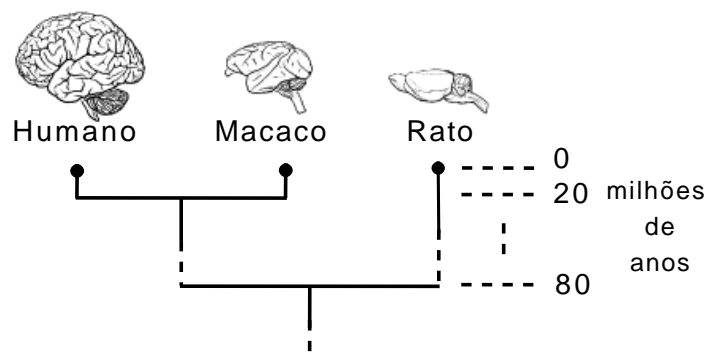

Figura 2.1: Evolução do sistema nervoso. Adaptado de (DORUS et al., 2004, p. 1028).

Outros trabalhos investigaram o comportamento individual de neurônios, em particular o neurônio gigante da lula, conduzindo ao modelo matemático proposto por Hodgkin e Huxley (1952), formado por um conjunto de equações diferenciais não-lineares descrevendo a atividade elétrica da membrana da célula nervosa em função do estado de seus canais de sódio e potássio, dentre outros. Outro avanço importante é creditado a Hebb (1949) que, a partir de suas observações, postulou um princípio pelo qual as células nervosas se comunicam e criam conexões. Uma compreensão mais detalhada na formação de sinapses e na transmissão de impulsos pré-sináticos para os pós-sinápticos através de neurotransmissores, motivaram a proposição de novas regras de aprendizado em neurônios artificiais (ROJAS, 1996; HAYKIN, 1998).

\subsubsection{Breve Histórico das Redes Neurais}

A história das redes neurais artificiais seguiu um caminho no mínimo curioso. O primeiro modelo de neurônio artificial surgiu em 1943 com o trabalho de McCulloch e Pitts (1943). Em seguida surgiram alguns trabalhos dos quais se destaca o de Rosenblatt (1958) com a criação de uma rede de neurônios chamada de Perceptrons, capaz de ser treinada para classificar padrões linearmente separáveis. A principal contribuição do trabalho de Rosenblatt está no algoritmo responsável pela atualização dos ganhos sinápticos, cujo princípio de funcionamento é baseado na resposta da rede ao vetor de entrada em comparação ao valor desejado: $w_{t+1}=w_{t}+c(o-y)$, onde o peso sináptico $w$ é corrigido por um fator $c$ da diferença entre o valor desejado $(o)$ e a saída $(y)$ do neurônio. A rede era formada por duas camadas (entrada e saída) composta por neurônios de McCullochPitts. A cada iteração todos os pesos são reajustados até que seja atingido um limite estabelecido para convergência.

O Perceptron pode ser visto simplesmente como um discriminador linear: dados 
conjuntos linearmente separáveis, o perceptron pode ser treinado num número finito de iterações para classificar estes conjuntos. A dificuldade é que, como mostraria Minsky e Papert (1969), o conjunto de problemas que podem ser resolvidos com separabilidade linear é muito restrito. Existia a conjectura de que uma rede multi-camada de perceptrons poderia ser treinada para classificar problemas com separabilidade não-linear, o problema era que não se conhecia uma técnica capaz de determinar os pesos da rede para que isso acontecesse (KOVACS, 2002).

Por estes, dentre outros motivos, o interesse em redes neurais só foi retomado na década de 1980 com o trabalho de Rumelhart e McClelland (1987), que tornaram famosa uma das técnicas mais conhecidas para o treinamento de perceptrons de múltiplas camadas, o algoritmo de retropropagação do erro (backpropagation). Além deles, o famoso trabalho de Hopfield (1982) aplica uma arquitetura neural para recuperar padrões através de seu conteúdo (memórias associativas). Por último, em 1987 tivemos o trabalho de Kohonen (HAYKIN, 1998), mostrando uma nova arquitetura capaz de reduzir a dimensão de um espaço $n$-dimensional preservando sua topologia, técnica bastante útil na categorização de dados.

Desde então, dezenas de outras arquiteturas foram propostas, a maior parte focada em resolver problemas relacionados à engenharia e computação. Abstrações matemáticas foram inseridas nos modelos de forma que fosse possível fazer afirmações e demonstrar certas propriedades. Em paralelo, a comunidade de neurociência computacional procurava aumentar o realismo biológico em seus modelos, onde os interesses se concentram em grandes áreas como aprendizado, memória ou distúrbios cognitivos (CHURCHLAND; SEJNOWSKI, 1994; O'REILLY; MUNAKATA, 2000; TRAPPENBERG, 2002).

\subsubsection{O Neurônio Artificial}

Dos avanços obtidos desde o trabalho de McCulloch e Pitts, podemos descrever resumidamente a primeira e segunda geração de neurônios artificiais da seguinte forma (MAAS, 1997). Para um neurônio com $n$ entradas (dendritos), sua ativação é dada por

$$
u=\sigma\left(\sum_{i=1}^{n} w_{i} x_{i}-\theta\right)
$$

onde $w_{i}$ representa os ganhos sinápticos (simplificando o papel dos neurotransmissores), sendo que $w_{i}>0$ corresponde a uma conexão excitatória e $w_{i}<0$ a uma inibitória. O limiar de disparo do neurônio pode ser representado pelo termo $\theta$ e $x_{i}$ indica o sinal 
de entrada, que pode ter origem externa (sensores de tato, por exemplo) ou interna (informação recebida de outro neurônio) (Figura 2.2). A função $\sigma$ é chamada de função de transferência, ou ativação. No modelo de McCulloch e Pitts a função de ativação levava em consideração a natureza "digital" do neurônio, i.e, dispara ou não:

$$
\sigma=\left\{\begin{array}{lll}
1 & \text { se } & \sum w x>\theta \\
0 & \text { se } & \sum w x<\theta
\end{array}\right.
$$

Embora bastante rudimentar, o modelo leva em consideração algumas das principais características do neurônio biológico: (1) integração da informação recebida, (2) existência de conexões inibitórias e excitatórias que (3) podiam cooperar ou não para o disparo do neurônio, caso o limiar fosse ultrapassado.

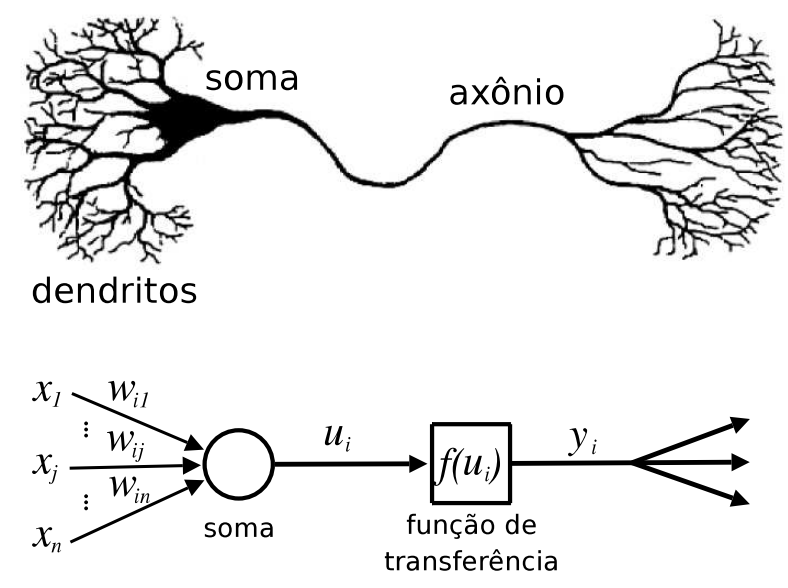

Figura 2.2: Neurônio biológico e seu modelo matemático.

Nos anos seguintes, novas funções de transferências foram experimentadas, procurando representar a taxa média de disparos de um neurônio por intervalo de tempo. A classe de funções contínuas sigmoidais (ou s-shaped) se comporta de forma similar à taxa-média de disparos de um neurônio em função de suas entradas, considerando seu nível de saturação. Normalmente, usa-se a função logística

$$
\sigma(z)=\frac{1}{1+e^{-c z}}
$$

restringindo a saída no intervalo $(0,1)$, ou a função tangente hiperbólica

$$
\sigma(z)=\tanh c z
$$

cuja saída pertence ao intervalo $(-1,1)$. Em ambas as funções, podemos adicionar um parâmetro $(c)$ que controla a "abertura" da função. Note que para $c \rightarrow \infty, \sigma(z)$ se 
aproxima da função 2.2 .

Diversos resultados puderam ser derivados de redes empregando tais modelos. Talvez os mais famosos sejam creditados a Cybenko (1989) que, utilizando o resultado obtido por Komolgorov sobre aproximação de funções contínuas, mostrou que uma rede de Perceptrons com uma única camada oculta é capaz de aproximar arbitrariamente qualquer função contínua definida num intervalo compacto.

\subsubsection{Topologias de Redes Neurais}

A topologia da rede define como os neurônios são conectados entre si. Existem basicamente dois tipos de topologias, conhecidas por propagação direta (feed-forward) e recorrentes (feed-back). No primeiro caso a informação da entrada é transferida para as próximas camadas até os neurônios de saída, seguindo uma única direção (Figura 2.3(a)). Nas topologias recorrentes existe pelo menos uma conexão recursiva, conectando a saída de um neurônio à entrada de outro que o preceda ou a ele próprio (Figura 2.3(b)). No primeiro a rede se comporta de forma estática, mapeando um ponto do espaço $\mathbb{R}^{m}$ em $\mathbb{R}^{n}$. No segundo caso a rede apresenta um comportamento dinâmico, isto é, mesmo na ausência de entradas a rede é capaz de continuar produzindo atividade, fazendo com que as conexões recorrentes implementem algo parecido com "memória".

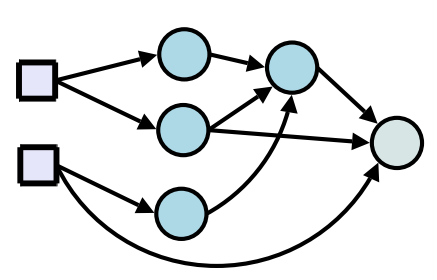

(a) Topologia propogação direta (feedforward)

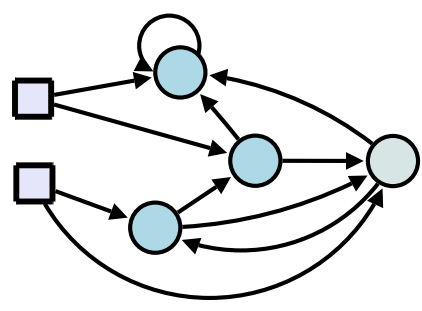

(b) Topologia recorrente (feedback)

Figura 2.3: Diferentes topologias de rede.

Grande parte das redes neurais utilizadas na prática se baseia em arquiteturas feedforward, dada a simplicidade de análise e do desenvolvimento de algoritmos de aprendizado. No entanto, como as redes recorrentes são capazes de manter um estado interno ao longo do tempo, podendo produzir dinâmicas ricas, sua aplicação em Vida Artificial é especialmente interessante quando se pretende estudar comportamento adaptativo. Além de representarem um modelo mais próximo à biologia, do ponto de vista da aplicação de algoritmos genéticos não há qualquer diferença sobre qual tipo de arquitetura usado. Outro resultado importante é a equivalência entre uma rede neural 
recorrente e a máquina de Turing (HYOETYNIEMI, 1996). A prova é feita por construção.

\subsubsection{Aprendizado em Redes Neurais}

A variação dos pesos sinápticos em redes neurais (representados por $w_{i}$ na equação 2.1, p. 23) com o objetivo de realizar alguma função é chamada de aprendizado. Esta capacidade permite que a rede memorize padrões ou ainda faça generalizações, conseguindo classificar entradas que nunca tinham sido apresentadas.

Existem basicamente três tipos de aprendizado: supervisionado, não supervisionado e por reforço. No aprendizado supervisionado temos um conjunto de treinamento, onde conhecemos a resposta para um dado conjunto de entradas. Através de algum método os pesos são ajustados para reproduzir a tabela de treinamento, o que na prática significa que estamos simplesmente aproximando uma função. Já no aprendizado não supervisionado (as vezes chamado de "sem professor") a rede recebe entradas e determina suas saídas conforme sua regra de aprendizado. Neste caso não existe um ponto definido para o qual cada entrada deva corresponder, a regra de aprendizado deve ser capaz de extrair características do conjunto de entradas e portanto técnicas deste tipo são muitas vezes usadas em mineração de dados (ROJAS, 1996). Na última vertente, chamada de aprendizado por reforço, para cada entrada fornecida à rede, uma regra decide o quão bem, ou mal, a rede respondeu naquele instante. Este tipo de técnica compartilha muitas semelhanças com o aprendizado evolucionário, e será estudado nos próximos capítulos.

Um exemplo de aprendizado não supervisionado é dado pelo princípio de Hebb, onde dois neurônios tendem a intensificar sua conexão se disparam ao mesmo tempo. A regra de atualização da sinapse leva em consideração seu estado no passo de tempo anterior, da seguinte forma:

$$
w^{t+1}=w^{t}+\eta\left(1-w^{t}\right) x y
$$

onde $x$ é o sinal de entrada do neurônio, $y$ sua respectiva saída e $\eta$ a taxa de aprendizado. Essa regra pode ser aplicada em qualquer topologia de rede e exige apenas informação local do neurônio, não importando o que ocorra na rede como um todo. O aprendizado Hebbiano, e suas variantes, pode ser usado para extração de componentes principais (ROJAS, 1996; HAYKIN, 1998).

No aprendizado supervisionado, o método mais famoso é conhecido por retropropagação do erro (backpropagation) (HAYKIN, 1998). Nesse caso o problema de treinar uma rede neural pode ser visto como um problema de otimização onde devemos encontrar o mínimo de uma certa função objetivo. Um inconveniente desta técnica é que muitas 
vezes o processo de minimização de erro fica preso num mínimo local, impedindo a convergência (KOVACS, 2002).

\subsubsection{Ativação de Redes Neurais Artificiais}

Um fato pouco discutido na literatura sobre redes neurais é a ordem que se deve seguir na ativação dos neurônios numa rede neural de topologia arbitrária. Geralmente, em redes do tipo feedforward, a partir da camada de entrada, a ativação é feita de camada em camada até a saída, sendo que todos os neurônios de cada camada são ativados paralelamente. A Figura 2.4 ilustra esse processo.

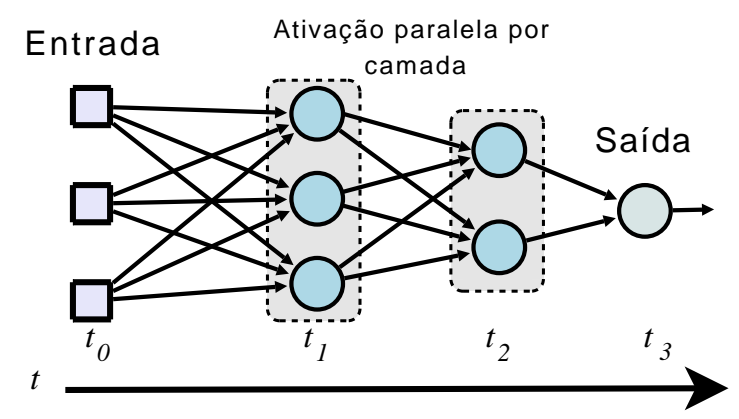

Figura 2.4: Ativação por camadas numa rede feedforward.

Esta mesma metodologia não se aplica para redes recorrentes já que a ativação de um dado neurônio pode fazer uso do seu próprio estado ou de outros neurônios no passo anterior. Nestes casos é necessário pensar na rede como um sistema dinâmico discreto, de forma que a cada instante de tempo temos um estado da rede, podendo ser representado por um vetor onde cada componente é a ativação (saída) de cada neurônio. Na Figura 2.5 o estado do neurônio $i$ no instante $t$ é indicado por $N_{i}^{t}$. De maneira similar, os sensores indicam o valor recebido $\left(I_{i}^{t}\right)$.

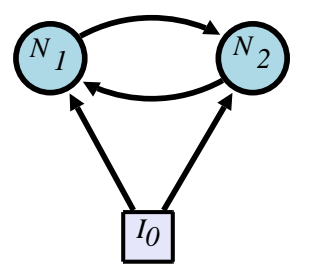

$$
\begin{aligned}
& {\left[\begin{array}{lll}
I_{0}^{(0)} & N_{1}^{(0)} & N_{2}^{(0)}
\end{array}\right]} \\
& {\left[\begin{array}{lll}
I_{0}^{(l)} & N_{1}^{(l)} & N_{2}^{(l)}
\end{array}\right]} \\
& {\left[\begin{array}{lll}
I_{0}^{(t)} & N_{1}^{(t)} & N_{2}^{(t)}
\end{array}\right]}
\end{aligned}
$$

Figura 2.5: Ativação paralela numa rede recorrente.

Para o caso recorrente, existem basicamente duas formas de ativação: assíncrona ou síncrona. No primeiro caso escolhe-se aleatoriamente um neurônio da rede que será ativado usando o estado atual da rede. Assim que o neurônio é ativado, o vetor de estado é 
alterado conforme novas ativações ocorrem. Já no caso onde a ativação é síncrona, todos os neurônios são atualizados ao mesmo tempo usando somente informações do estado anterior da rede.

Também é muito comum se trabalhar matricialmente com redes neurais, já que sua topologia e conexões sinápticas podem ser representadas por uma matriz, onde cada elemento $a_{i j}$ representa a sinapse entre o neurônio $i$ e $j$ (Figura 2.6). Um elemento nulo significa que não há conexão. Desta forma é possível abstrair a idéia de que estamos trabalhando com uma rede de neurônios artificiais já que valem todas as operações usuais do espaço das matrizes. Este tipo de notação é conveniente quando estamos interessados em estudar algumas propriedades gerais de redes neurais, e como estas se comportam sob certas condições.

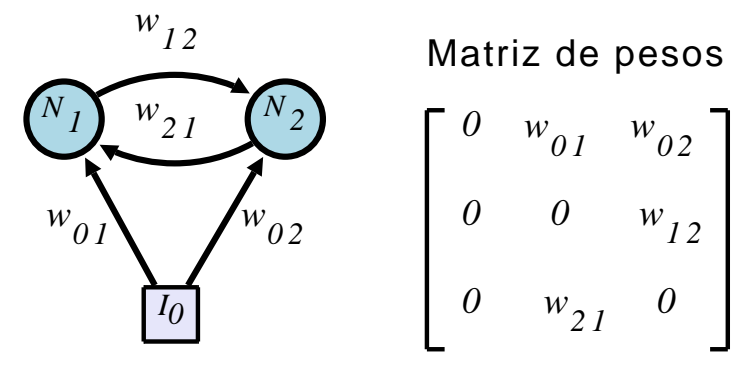

Figura 2.6: Representação matricial de uma rede neural.

\subsubsection{Redes Recorrentes de Tempo-Contínuo}

Enquanto redes com topologias feedforward servem bem para modelar comportamentos reativos (respondem sempre da mesma forma para um dado estímulo), não servem como modelo para comportamentos deliberativos, ou proativos (a resposta pode alterar com o tempo, mesmo com a persistência do estímulo). Como os neurônios, modelados pela Equação 2.1, não mantêm um estado interno, não há como resgatar a memória do passo anterior e portanto a saída da rede depende exclusivamente das entradas sensórias e eventualmente de neurônios internos (aqueles que não recebem informações sensoriais). Como já foi dito, as redes neurais recorrentes permitem um certo grau de memória já que o próprio neurônio pode ter uma conexão com ele mesmo ou de outro neurônio no qual sua ativação dependa deste neurônio.

Com a adição de conexões recorrentes o neurônio tem a ativação influenciada pelos passos anteriores, permitindo que comportamentos deliberativos sejam possíveis. Apesar desta possibilidade, outra característica interessante num modelo seria a capacidade do 
neurônio alterar seu estado em função do tempo, ou seja, que sua freqüência média de disparos varie continuamente no tempo assim como em neurônios biológicos, diferente da ativação em passos discretos dos modelos tradicionais (PFEIFER; SCHEIER, 1999). A variação do seu estado também permite um tipo de memória de curto prazo, além de poder apresentar atividade mesmo na ausência de estímulos sensoriais.

A classe de modelos que cumprem este papel é conhecida por "integrador com perda" (leaky-integrator ${ }^{1}$ ) (BEER; GALLAGHER, 1992). As Redes Neurais Recorrentes de TempoContínuo (daqui em diante chamadas de CTRNNs, do inglês Continuous-Time Recurrent Neural Networks) foram popularizadas como um modelo do tipo leaky-integrator por Hopfield e Tank (1986) e Beer e Gallagher (1992), principalmente na área de robótica evolutiva (NOLFI; FLOREANO, 2000; HARVEY et al., 2005; FLOREANO; DÜRR; MATTIUSSI, 2008), dado que este tipo de neurônio mantém similaridade em comparação aos modelos anteriores, além de apresentar características importantes: 1) integração de estímulos no tempo, 2) estado interno variável (em analogia ao potencial da membrana) e 3) capacidade de alterar seu estado dinamicamente mesmo na ausência de conexões recorrentes ou estímulos externos (BLYNEL; FLOREANO, 2002).

O comportamento de uma CTRNN é descrito por um sistema de equações diferenciais da seguinte forma:

$$
\tau_{i} \frac{d y_{i}}{d t}=-y_{i}+\sum_{j=1}^{N} w_{j i} \sigma\left(y_{j}-\theta_{j}\right)+\sum_{k=1}^{S} S_{k i} I_{k}
$$

onde $N$ é o número total de neurônios na rede, $y_{i}$ é o estado interno do neurônio $i, \tau_{i}$ é a constante de tempo (taxa de decaimento), $w_{j i}$ é a conexão sináptica entre o neurônio $i$ e $j, S$ é o número de entradas sensoriais, $I_{k}$ é o estímulo recebido pelo sensor $k$ e $S_{k i}$ é a conexão sináptica do sensor $k$ com o neurônio $i$. A resposta do neurônio é dada pela função $(\sigma)$, geralmente representada pela expressão logística (Equação 2.3). Cada neurônio numa CTRNN possui, além dos atributos dos modelos tradicionais, uma constante de tempo que determina o quão rápido a célula altera seu estado em função do tempo, e portanto este tipo de modelo também é conhecido por neurônio dinâmico.

Pode-se dizer que as CTRNNs são a versão contínua do modelo tradicional, sendo especialmente apropriadas para aplicações onde o tempo varia continuamente, como é o caso em simulações de Vida Artificial (YAMAUCHI; BEER, 1994; STANLEY, 2004). Os principais trabalhos atualmente envolvem navegação, obtenção de comportamentos

\footnotetext{
${ }^{1} \mathrm{O}$ nome vem da analogia com circuitos elétricos, onde a ativação da célula seria equivalente à diferença de potencial de um capacitor que gradualmente perde uma pequena quantia de energia ao longo do tempo (FLOREANO; DÜRR; MATTIUSSI, 2008).
} 
rítmicos ou memórias associativas (BEER, 1990, 2006; THUV, 2007).

\subsubsection{Modelos Neurais Pulsados}

Classificado por Maas (1997) como a terceira geração de modelos neurais, a redes de neurônios pulsados são computacionalmente mais poderosas que os modelos discretos de McCulloch e Pitts ou de funções sigmodais (FLORIAN, 2003). Existem exemplos mostrando funções que podem ser aproximadas por um único neurônio pulsado, mas que no entanto exigem uma rede com dezenas de neurônios sigmodais (MAAS, 1997).

Em geral os modelos pulsados são formulados baseados nas equações de HodgkinHuxley, e apresentam uma rica dinâmica de comportamentos, podendo ser estudados do ponto de vista de sistemas dinâmicos discretos ou contínuos (HERNANDEZ, 1998, 2001; IZHIKEVICH, 2007).

\subsection{Evolução e Algoritmos Genéticos}

Geralmente usamos algoritmos genéticos para resolver problemas práticos de engenharia ou computação. Embora sua aplicação como método alternativo às técnicas tradicionais de otimização contínua e combinatória tenha sido promissora, a idéia original introduzida por Holland (2001) era de se criar um modelo computacional capaz de reproduzir os principais mecanismos da evolução por seleção natural (MITCHELL, 1996, p. 65).

\subsubsection{Complexidade e Emergência}

Modelos matemáticos que descrevem a interação entre espécies são passíveis de análise a partir da solução analítica em casos simples, embora capturem somente a dinâmica geral das espécies, ou o que chamamos de comportamento qualitativo. Modelos mais detalhados tornam difícil a análise, onde geralmente o comportamento global é estudado através da solução numérica de sistemas de equações diferenciais. Por outro lado, temos a possibilidade de simular uma população suficientemente grande de indivíduos interagindo entre si localmente, sendo que as propriedades globais deste sistema são um resultado emergente. Numa simples simulação multi-agentes é possível reproduzir o mesmo comportamento da dinâmica predador-presa das equações de LotkaVolterra (NEVES, 2003, p. 97). Em Vida Artificial, a noção de emergência ou, em particular, comportamento emergente é de grande importância. Muitos sistemas naturais 
apresentam comportamento, ou propriedades emergentes, que são resultados coletivos de todo o grupo e não somente de um indivíduo. Em geral são comportamentos que não foram previstos, isto é, não foram programados ou planejados, simplesmente surgem nessa estrutura, de maneira espontânea (BAK, 1999).

$\mathrm{Na}$ natureza existem diversos exemplos de fenômenos emergentes, como o comportamento em sociedades, ou mesmo em colônia de insetos, além da operação dos sistemas imunológicos e a própria organização do sistema nervoso (HOLLAND, 2001). É possível também observar emergência em situações mais simples, por exemplo, na ebulição da água (observadas em transições de fase medidas na sua temperatura e pressão). Ambos ocorrem devido a interações moleculares, escala em que não faz sentido falar sobre pressão ou temperatura, que são grandezas estatísticas macroscópicas. Em geral, fenômenos resultantes da interação de unidades fundamentais, como insetos ou células nervosas, são conhecidos por Sistemas Complexos (NUSSEnZVEIG, 1999).

\subsubsection{Evolução}

A evolução é o processo pelo qual novas características são adicionadas ao sistema, mantendo aquelas que trouxeram algum benefício aos seus elementos (indivíduos) e eliminando outras que os prejudicaram. O comportamento social de uma espécie, por exemplo, seria um resultado emergente da interação comportamental de cada indivíduo, que por sua vez é obtido através de aprendizado ou herdado de gerações anteriores. Considerando organismos que desenvolveram algum tipo de sistema nervoso, o qual controla seu comportamento e aprendizado, seria possível simular a adaptação da espécie através de algum modelo capaz de reproduzir as características básicas dessa dinâmica.

Embora tais abordagens sejam interessantes como modelos da evolução natural, é preciso ressaltar as limitações da abordagem computacional. É necessário criar um balanço entre o nível de detalhe que pretendemos inserir no modelo e o tempo que estamos dispostos a gastar na simulação. Os principais conceitos de algoritmo genético nos mostram, independente do tipo de estrutura inicial, como obter novos indivíduos através da reprodução e seleção, podendo ser aplicado a qualquer tipo de problema que possa ser descrito nestes termos. 


\subsubsection{Principais Conceitos de AGs}

Num algoritmo genético, cada indivíduo é descrito por um conjunto de parâmetros, chamado de "genoma" ou "cromossomo" 2. Os cromossomos são compostos por genes, que guardam características que representam o organismo em si, o fenótipo. Cada gene pode assumir um dentre diversos "estados", chamados de alelos. Uma configuração particular do genoma (cromossomo) é chamada de genótipo (Figura 2.7).

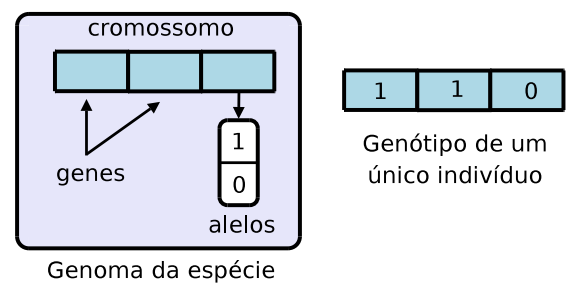

Figura 2.7: Representação do cromossomo.

O algoritmo genético opera diretamente sob a estrutura definida pelo genótipo. Diante desta flexibilidade, qualquer tipo de estrutura pode ser codificada num genótipo, desde os coeficientes de uma equação polinomial até mesmo as regras locais que ditam como cada gene será usado na construção do sistema nervoso. A evolução acontece quando uma população de genótipos sofre mutações ao longo do tempo, alterando a freqüência de alelos que surgem em cada geração. Em geral os genes cujos alelos trazem algum benefício ao indivíduo, e por conseqüência à população, tendem a se distribuir pela população através da reprodução nas próximas gerações, aumentando sua freqüência. De maneira oposta, indivíduos que carregam genes que não trazem qualquer vantagem reprodutiva a si mesmos tendem a ter menores chances de reprodução (seleção natural), diminuindo sua freqüência nas próximas gerações. Por fim, é necessário um critério de seleção para se identificar quais dentre os indivíduos devem ser escolhidos para formar a nova população para a próxima geração.

\subsubsection{Modelo Básico de Algoritmo Genético}

O modelo mais simples de algoritmo genético é apresentado na Figura 2.8. Independente do problema a ser estudado, a estrutura básica do algoritmo genético é a mesma. Um laço

\footnotetext{
${ }^{2} \mathrm{Na}$ Biologia, genoma e cromossomo não significam a mesma coisa. Por exemplo, o genoma humano é constituído de 23 pares de cromossomos. Além disto o termo genoma se presta para fazer referência ao conjunto (humanidade) enquanto que o cromossomo (ou um conjunto desses) está associado a um indivíduo. Em Vida Artificial geralmente usamos apenas um cromossomo por organismo, e neste caso os termos coincidem.
} 
onde a cada geração avaliamos todos os indivíduos e selecionamos alguns para reproduzir e gerar uma nova população. A única variação entre um problema e outro está em como tratar cada indivíduo, de que forma aplicar os operadores genéticos e que critérios usar para selecioná-los, ou seja, como medir efetivamente a qualidade de cada indivíduo, dada por um número denominado valor adaptativo ${ }^{3}$.

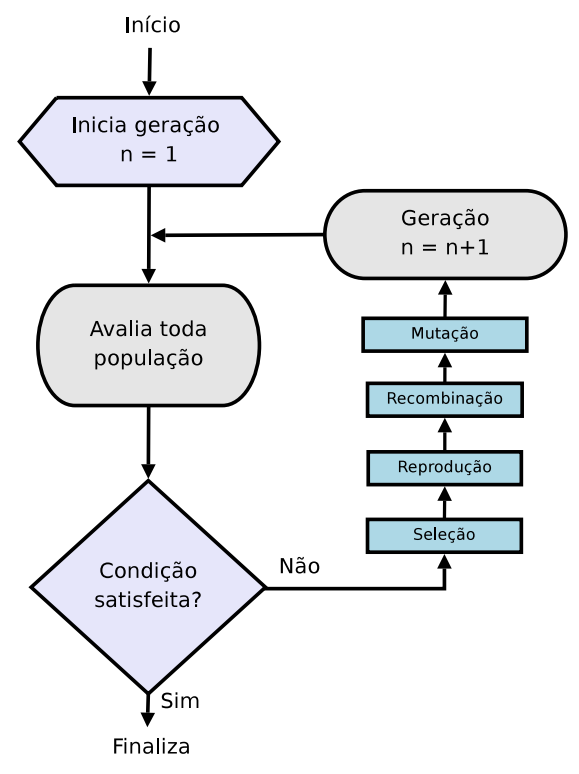

Figura 2.8: Representação do Algoritmo Genético Padrão.

Em algoritmos genéticos, a forma com que selecionamos indivíduos de uma população tem importância fundamental. Este é o processo pelo qual indivíduos são escolhidos para formar a nova geração através dos operadores genéticos. Dependendo do problema tratado, algumas vezes pode ser vantajoso selecionar indivíduos com um maior valor adaptativo na avaliação de uma certa função, enquanto outras vezes não. Os métodos descritos a seguir são capazes de tratar ambos os casos sem perda de generalidade.

\subsubsection{Seleção Truncada}

A seleção truncada é um dos métodos mais simples. Todos os indivíduos da população são ordenados segundo seu valor adaptativo. Em seguida, uma porcentagem fixa dos indivíduos menos aptos é descartada. Intuitivamente pode parecer que somente os melhores indivíduos sejam interessantes para formar a próxima geração. Acontece que isto nem sempre é verdade, já que alguns alelos nos indivíduos menos aptos podem mostrar vantagens nas próximas gerações. Este método também pode convergir rapidamente para

\footnotetext{
${ }^{3}$ Do inglês: fitness
} 
um mínimo local, já que elimina a diversidade nas primeiras gerações (MICHALEWICZ, 1998).

\subsubsection{Seleção por Roleta}

Na seleção por roleta, cada indivíduo tem uma probabilidade de ser selecionado segundo seu valor adaptativo. Indivíduos mais aptos têm uma probabilidade maior e vice-versa. Ao contrário da seleção truncada, este método permite que indivíduos menos aptos ainda tenham uma chance de serem selecionados. No entanto há uma chance de se perder bons indivíduos.

\subsubsection{Seleção por Torneio}

Neste método, escolhemos aleatoriamente $k$ indivíduos da população ( $k$ é chamado de "tamanho do torneio"). Os indivíduos escolhidos são ordenados pelo seu valor de adaptativo. Cada um destes indivíduos $(i=1 \ldots k)$ será selecionado com probabilidade $p(1-p)^{i-1}$, onde $p$ é um parâmetro estabelecido antes da seleção ocorrer. No caso em que $p=1$, temos a Seleção por Torneio determinística, sempre selecionando o melhor indivíduo do grupo. Se $k=1$ a seleção é equivalente a uma escolha aleatória. Ao final do processo de seleção, pode-se optar em manter o mesmo indivíduo na população permitindo que o mesmo seja escolhido mais de uma vez, ou removê-lo de forma que novos indivíduos tenham a chance de serem selecionados.

Do ponto de vista computacional, a seleção por torneio geralmente é escolhida por ser facilmente implementada em código e, do ponto de vista matemático, permite que a pressão seletiva seja ajustada conforme o problema, possibilitando uma taxa de seleção dinâmica ao longo das gerações. Embora não resolva o problema, diminui as chances do algoritmo genético encontrar mínimos/máximos locais (DRCHAL, 2006).

\subsubsection{Codificação}

Os operadores de recombinação (ou cruzamento) e mutação variam conforme a codificação genética usada para representar uma possível solução do problema. Se estamos lidando com problemas de otimização, geralmente a solução do problema é um vetor $n$-dimensional e portanto nosso interesse é encontrar uma codificação para este vetor de tal forma que faça sentido aplicar os operadores genéticos. Em outras situações a solução do problema pode ser uma estrutura de dados, um caminho possível num grafo cíclico ou até mesmo 
uma topologia de rede neural. Cada problema exige uma codificação específica e portanto operadores genéticos particulares.

Para ilustrar o problema, suponha que estejamos interessados em encontrar o mínimo da função $f(x)$ onde $x \in S=\{0<x<1\}$. Desta forma, procuramos por $x *$ tal que $f(x *)<=f(x) \forall x \in S$. Aqui o fenótipo de cada indivíduo da população é um número $x \in S$ e seu valor adaptativo (fitness) é dado pela própria $f(x)$. Portanto neste problema estamos interessados em indivíduos cujo valor adaptativo seja o menor da faixa pesquisada. Precisamos agora encontrar uma codificação genética que represente o conjunto de indivíduos possíveis neste exemplo particular. Uma forma bastante utilizada nos primeiros experimentos com algoritmos genéticos é a codificação binária que utiliza uma lista de genes onde os alelos possíveis são 1 e 0 . Como queremos listas de tamanho finito, isto impõe uma restrição sobre o conjunto de possíveis candidatos à solução, que neste caso em particular, incide diretamente na precisão numérica de $x$ já que estamos discretizando o espaço $S$.

Suponha que uma solução satisfatória tenha o erro inferior a $10^{-4}$. Para alcançarmos essa precisão com representação binária, é necessário um genótipo que contenha 10 genes. Como nosso domínio está em $[0,1]$, não precisamos nos preocupar com uma representação binária de ponto-flutuante, bastando apenas uma codificação capaz de representar números racionais entre 0,000 e 0,999. Neste intervalo temos 1.000 possibilidades diferentes e, portanto, 10 genes são suficientes já que $2^{10}=1.023$. Se tivéssemos limitado o cromossomo a 9 genes perderíamos a precisão desejada já que apenas 512 possíveis números podem ser representados em binário (Figura 2.9).

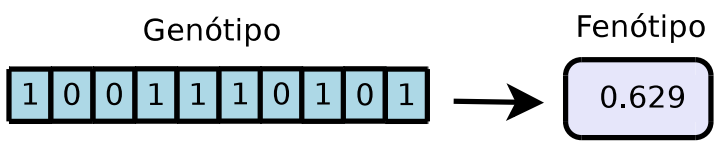

Figura 2.9: Mapeamento do genótipo para o fenótipo.

Como neste exemplo a população de soluções candidatas (indivíduos) são representadas de forma binária, é necessário fazer a conversão para um número racional (no intervalo $[0,1])$ no momento em que cada indivíduo for avaliado por $f(x)$. Note que essa transformação do genótipo em fenótipo só é necessária neste instante já que os operadores genéticos inserem variação na população no nível genético, ou seja, trabalham direto com os genes binários, não importando o seu fenótipo (neste caso, um número racional). Também não há restrições sobre o tipo de função de avaliação de aptidão $(f(x))$, podendo ser uma simples função elementar ou um conjunto de equações que descrevam 
um ambiente complexo e dinâmico, com obstáculos e outros indivíduos interagindo entre si, por exemplo.

\subsubsection{Operadores Genéticos}

Os operadores genéticos procuram imitar o processo natural de reprodução e são responsáveis pela inserção de variabilidade genética na população. Formalmente, podemos definí-los genericamente da seguinte forma

$$
O: G^{n} \times P \rightarrow G^{m}, n, m>=1
$$

onde $n$ e $m$ são as dimensões do espaço $G$ de genótipos e $P$ um conjunto de parâmetros. Os operadores de recombinação (crossover), isto é, como combinar $n$ indivíduos (pais) para gerar $m$ novos (filhos), podem ser definidos de diversas formas. No Algoritmo Genético padrão, temos

$$
R: G^{2} \times P \rightarrow G^{2}
$$

ou seja, dois indivíduos da população $(G)$ são selecionados (usando, por exemplo, seleção por roleta) para produzirem dois novos indivíduos. A Figura 2.10 ilustra um possível operador conhecido por recombinação de um único ponto. Nesta situação, o conjunto de parâmetros $P$ é formado por inteiros entre 1 e $n$ (tamanho do genótipo). Na aplicação do operador, um elemento $p_{i}$ de $P$ é escolhido aleatoriamente para determinar um ponto onde os genótipos serão separados para recombiná-los. Na maioria dos casos usamos uma distribuição de probabilidade uniforme para escolher $p_{i}$, embora existam variações que podem muitas vezes melhorar o desempenho do algoritmo (MICHALEWICZ, 1998).

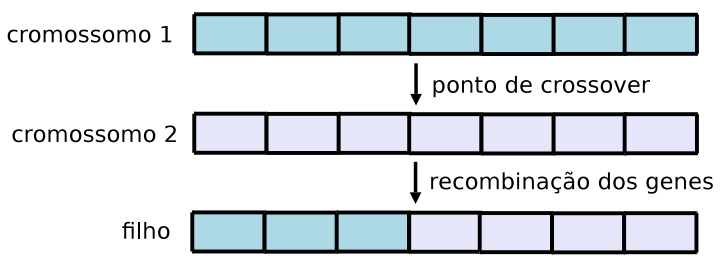

Figura 2.10: Recombinação por um único ponto.

Por último definimos o operador de mutação como

$$
M: G^{1} \times P \rightarrow G^{1}
$$

Ao contrário do operador de recombinação, aqui introduzimos perturbações nos novos genótipos, aumentando a variabilidade da população. Também serve de analogia à reprodução assexuada, onde não há troca de material genético entre os indivíduos. Esta 
situação ocorre numa outra classe de computação evolutiva conhecida por Programação Evolutiva (MICHALEWICZ, 1998).

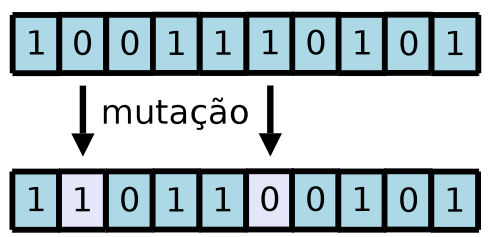

Figura 2.11: Exemplo de mutação binária.

A Figura 2.11 mostra dois operadores de mutação comuns para codificação binária. Existem diversas maneiras de adicionarmos variabilidade genética nos indivíduos da população, como mutação por incremento (o valor atual do gene é apenas levemente alterado) ou mutação total, onde o gene é substituído completamente. Em genótipos onde o número de genes é variável, é possível também adicionar novos genes aumentando a complexidade ${ }^{4}$ do genótipo e a capacidade de armazenar informação.

\subsubsection{Especiação}

Na natureza temos diversas espécies convivendo entre si e muitas vezes competindo por recursos do ambiente. Essa característica pode também ser simulada por algoritmos genéticos empregando métodos de especiação. Até agora nossa discussão envolvia a evolução de uma única espécie, o que na prática pode levar à homogenização de todos os indivíduos após algumas gerações. Do ponto de vista de otimização, isto significa que a população encontrou um mínimo ou máximo local na paisagem adaptativa ${ }^{5}$ e a adição de perturbações através da mutação não é mais suficiente para diversificar a população a ponto de explorar melhor o espaço de busca.

Desta forma, a necessidade em empregar métodos de especiação vem do interesse em se aproximar do que ocorre naturalmente na biologia ou de evitar restrições na exploração deste espaço. Assim como acontece num algoritmo genético, o processo evolutivo natural percorre um espaço de dimensão finita (embora para fins práticos, pode-se considerá-la infinita) representado pelas quatro bases nucléicas (DAWKINS, 2001). Diferentes espécies exploram diferentes regiões deste espaço, e são justamente estas características que procurarmos reproduzir numa simulação.

\footnotetext{
${ }^{4}$ Complexidade no sentido de Kolmogorov. Com a inserção de novos genes há um aumento de combinações possíveis e, por conseqüência, da entropia (ADAMI, 1998).

${ }^{5}$ Do inglês, fitness landscape: representa todos os possíveis genótipos e seus respectivos valores adaptativos (SILVA, 2005, p. 22).
} 
Embora o conceito de espécie, assim como discutido na biologia, seja de difícil definição, os métodos de especiação se baseiam na distância por similaridade (fenotípica ou genotípica) de cada indivíduo, ou seja $d(i, j), i, j \in I$, onde $I$ é o conjunto de todos os possíveis indivíduos. A métrica $d$ é definida de tal forma que o quão mais próximos os indivíduos $i$ e $j$ estiverem, menor será sua distância. Uma possível métrica para o exemplo de genótipo binário discutido anteriormente seria a distância de Hamming (quantos genes diferem entre dois indivíduos).

Outra vantagem, do ponto de vista computacional, em métodos de especiação é o grau de paralelismo que se consegue obter. Diferentes espécies podem ser avaliadas independentemente umas das outras em processadores ou máquinas distintas, já que o gargalo nas simulações com algoritmos genéticos acontece no momento da avaliação de cada indivíduo (STANLEY; MIIKKULAINEN, 2002). 


\section{Neuroevolução}

Em vida artificial muitas vezes estamos interessados em utilizar redes neurais para o controle de organismos artificiais situados num determinado ambiente. Cada organismo pode, por exemplo, carregar instruções codificadas de como sua rede neural é construída, de forma que possamos aplicar algoritmos genéticos e permitir que os pesos sinápticos da rede, ou sua própria topologia, possa evoluir ao longo das gerações.

Como vimos no capítulo 2, a topologia da rede tem uma grande influência no seu comportamento e, por conseqüência, em como o organismo atua no ambiente. Diferente das técnicas de aprendizado, não existe uma metodologia eficiente e suficientemente genérica capaz de determinar a melhor forma com que os neurônios devam ser conectados (YAO, 1993). A questão se torna ainda mais complexa quando não sabemos exatamente o que a rede deva ser capaz de fazer para guiar o organismo artificial a fim de realizar uma determinada tarefa. Embora esse seja o típico problema encontrado na área de Aprendizado por Reforço (KAELBLING; LITTMAN; MOORE, 1996), nossa estratégia aqui será inspirada na evolução biológica.

Neste capítulo vamos estudar maneiras de combinar redes neurais e algoritmos genéticos, formando uma área conhecida por neuroevolução. Aplicações deste tipo atendem a um propósito muito mais genérico do que seu uso em vida artificial, isto é, também podem servir como método em diversos problemas de engenharia, inteligência artificial, dentre outros. Começamos descrevendo alguns tipos comuns de codificação de redes neurais e o problema inerente ao operador de recombinação quando aplicado nestes tipos de estruturas. Em seguida temos uma breve descrição sobre os diferentes tipos de algoritmos em neuroevolução e algumas propostas.

\subsection{Codificação Genética de Redes Neurais}

Seguindo a mesma abordagem usada em algoritmos genéticos, primeiro é preciso definir o fenótipo (neste caso a própria rede neural) e como este é representado pelo genótipo. 
Enquanto que os operadores genéticos trabalham somente com o genótipo, o valor adaptativo de cada organismo é obtido através do fenótipo, isto é, o quão bem a rede neural desempenhou para resolver o problema.

No contexto de Vida Artificial, em geral o fenótipo é o próprio organismo, formado pela sua morfologia (sensores e atuadores) e, principalmente, a rede neural. Normalmente a morfologia é pré-definida, exigindo que apenas a rede neural seja representada pelo genótipo. Porém, nada impede de codificarmos o fenótipo por completo, permitindo que a morfologia também evolua (SIMS, 1994b). Portando, é interessante que o genótipo seja flexível o bastante para guardar informações suficientes para a construção do fenótipo.

Existem dois tipos de codificação do fenótipo, a primeira e mais simples é chamada de direta, onde o cromossomo guarda todas as informações necessárias para construir o fenótipo, ou seja, ambos representam a mesma estrutura escrita de duas formas, uma com a qual o algoritmo genético possa trabalhar e outra para que se possa avaliar o desempenho do indivíduo. A segunda forma é conhecida por indireta, onde apenas as regras de construção são codificadas no genótipo, portanto o fenótipo é obtido através de um processo de desenvolvimento e, neste caso, não há uma relação de 1-para-1 entre ambos como acontece na codificação direta (STANLEY; MIIKKULAINEN, 2003).

Naturalmente o segundo tipo de codificação é o que temos de mais próximo da biologia, já que o DNA de organismos mais complexos (na escala filogenética) não guarda a informação completa de como construir o fenótipo. Um exemplo clássico que ilustra essa idéia é a comparação com a quantidade de neurônios e conexões no cérebro humano, pois seria impossível termos toda essa estrutura representada no DNA (DAWKINS, 2005).

\subsubsection{Codificação Direta}

A forma mais simples de representar uma rede neural num cromossomo é usando uma lista de genes guardando os pesos sinápticos das conexões. Fixando a topologia da rede, podemos estabelecer uma relação entre os genes e as conexões como mostra a Figura 3.1. A desvantagem nesse tipo de codificação está na necessidade de precisarmos de uma topologia pré-estabelecida. O cromossomo nada sabe sobre como os neurônios estão ligados, apenas sobre os pesos de cada conexão.

Outra forma possível é utilizar uma matriz de conectividade, onde o elemento na posição $(i, j)$ da matriz indica a existência de conexão entre o neurônio $i$ e $j$ com peso sináptico $w_{i j}$, conforme mostra a Figura 3.2. 


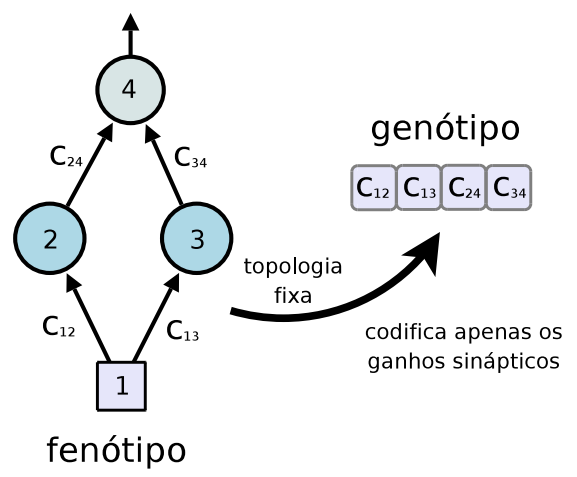

Figura 3.1: Exemplo de codificação neural direta.

Estas duas codificações não escalam bem para redes maiores e a primeira não permite o uso arbitrário de neurônios sem que toda a estrutura precise ser modificada (YAO, 1993). Enquanto a dimensão fixa da primeira restringe alterações topológicas da rede, incluindo sua expansão, a segunda requer uma redefinição da matriz se houver expansão da rede. Em outras palavras, só será interessante aplicar tais técnicas em problemas onde a topologia da rede é fixa e o algoritmo genético trabalha apenas com a evolução dos pesos. Essa estratégia é um tipo particular de algoritmos de neuroevolução, e compete com as técnicas tradicionais de aprendizado supervisionado como o algoritmo de retropropagação de erro, mostrando vantagens na solução de alguns problemas (GUPTA; SEXTON, 1999).

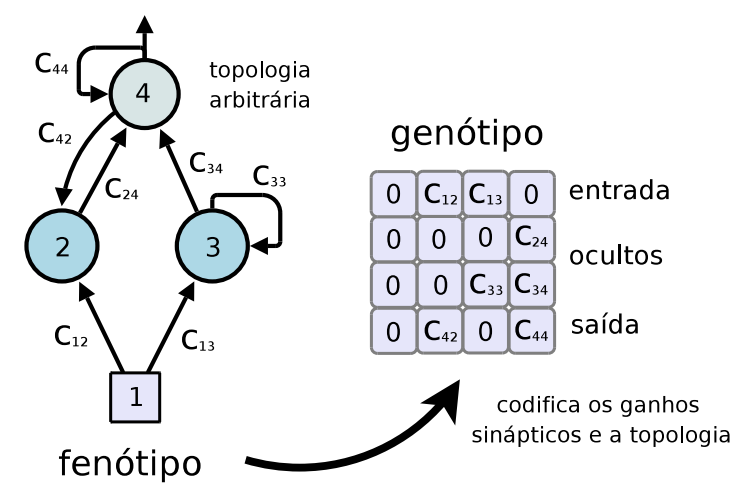

Figura 3.2: Exemplo de codificação neural matricial.

Uma forma mais eficaz de codificar redes neurais é usando listas ligadas e será apresentada na próxima seção.

\subsubsection{O Problema da Permutação}

Também conhecido por competing conventions, o problema da permutação torna a aplicação do operador genético de recombinação pouco eficiente. O problema é resultado 
da forma com que a topologia da rede é codificada no seu genótipo, podendo existir redes (fenótipos) funcionalmente equivalentes, mas com genótipos diferentes. Ao recombinarmos os dois genótipos acabamos descartando neurônios e duplicando outros, tornando o novo indivíduo uma combinação ineficiente dos seus pais (Figura 3.3).
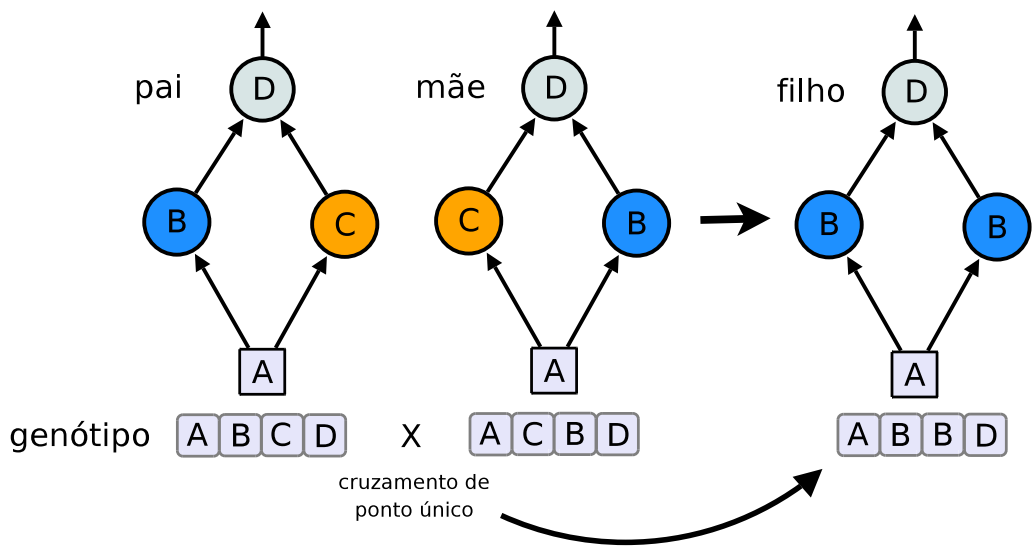

Figura 3.3: O problema da permutação em redes feed-forwards.

A principal dificuldade está em como identificar genes que desempenham funções similares numa população de genótipos. Por estes motivos, muitos métodos de neuroevolução omitem o operador de recombinação, e portanto aplicavam uma técnica evolutiva conhecida por Programação Evolutiva no lugar de Algoritmo Genético, onde a diversidade genética da população é resultado apenas dos operadores de mutação (YAO, 1993). O problema é acentuado quando consideramos topologias arbitrárias. Portanto, além da necessidade de usarmos uma codificação eficiente, isto é, que permita que a evolução aconteça sem restrições no tamanho do genótipo, precisamos encontrar um operador capaz de cruzar genótipos de tamanhos diferentes e onde cada gene homólogo (aqueles que desempenham um papel similar) seja levado em conta no instante do cruzamento.

A vantagem em usarmos recombinação, além da mutação, está diretamente relacionada às discussões sobre a evolução da reprodução sexuada na natureza (COLEGRAVE, 2002). O mesmo pode ser demonstrado empiricamente em um experimento comparativo. Quando não existe reprodução, o desempenho é inferior àquele usando recombinação genética (STANLEY, 2004). Este conceito torna-se muito mais importante em neuroevolução já que, como veremos na próxima seção, o uso de um operador de recombinação eficiente mostra vantagens significativas quando aplicado de maneira correta, contrariando a hipótese de que tal operador traria pouco benefício a ponto de poder ser descartado (ANGELINE; SAUNDERS; POLLACK, 1993). 


\subsection{Tipos de Neuroevolução}

Existem basicamente três linhas de estudo na aplicação de algoritmos genéticos (ou variações destes) em redes neurais. A primeira forma, e talvez a mais simples, consiste em obter os ganhos sinápticos de redes com topologias fixas, isto é, para um determinado problema a topologia é definida a priori (geralmente de forma empírica) e então se usam algoritmos genéticos para encontrar o conjunto de pesos ideal. Se o problema a ser resolvido for de aprendizado supervisionado, esta forma de neuroevolução pode ser uma alternativa a métodos como o backpropagation, geralmente aplicado em redes com topologia feedforward (SIDDIQUE; TOKHI, 2001).

O segundo tipo de neuroevolução envolve, além da obtenção dos ganhos sinápticos, determinar a própria topologia da rede neural. Dada sua grande importância, os métodos que fazem parte deste tipo de neuroevolução recebem uma denominação particular, conhecida por TWEANNs ${ }^{1}$.

No primeiro caso nosso espaço de busca se resume a um subconjunto de $\mathrm{R}^{n}$, onde $n$ é a quantidade de sinapses da rede. Para determinar a topologia, geralmente buscamos pontos no espaço das matrizes reais de ordem $n \times n$, cuja dimensão pode aumentar a cada geração, dependendo da quantidade $n$ de neurônios da rede ${ }^{2}$. O problema torna-se ainda mais complexo que o primeiro por diversos motivos. O espaço de busca aumenta significativamente, além disso, o uso de operadores de recombinação em redes com topologias diversas torna-se muito mais complicado e sujeito a obter redes inválidas (YAO, 1993). O terceiro tipo de neuroevolução consiste em aplicar algoritmos genéticos para obter parâmetros em regras de aprendizado (como a regra de Hebb) e geralmente é usado em conjunto com TWEANNs (CHALMERS, 1990; MITCHELL, 1996)

\subsection{NEAT}

Como o principal método deste trabalho é o NEAT (NeuroEvolution of Augmenting Topologies), esta seção discute de forma detalhada seu funcionamento. O texto a seguir segue basicamente o conteúdo das referências (STANLEY; MIIKKULAIEN, 2002; BUCKLAND, 2002; ADAMS, 2005; STANLEY, 2004).

Assim como os métodos de neuroevolução discutidos na seção anterior, o NEAT é uma proposta de algoritmo que cuida da evolução dos ganhos sinápticos e da própria

\footnotetext{
${ }^{1}$ Do inglês, Topology and Weights Evolving Neural Networks.

${ }^{2}$ Se considerarmos a representação matricial da rede neural, assim como uma estrutura em grafo.
} 
topologia da rede neural, não impondo nenhuma restrição sobre as possíveis configurações de sua arquitetura. Além disso, aborda as principais dificuldades encontradas nos métodos apresentados anteriormente:

1. Codificação genética flexível e suficientemente genérica;

2. Operadores genéticos apropriados para a codificação estabelecida;

3. Conceito de especiação, agrupando indivíduos similares na população;

4. Minimização do espaço de busca através de complexificação.

\subsubsection{Codificação Genética}

O NEAT emprega codificação genética direta, utilizando basicamente dois tipos de genes que codificam cada neurônio e conexão sináptica da rede neural. Portanto o genótipo de cada indivíduo da população carrega uma lista de genes que pode ser de tamanho arbitrário, possibilitando representar qualquer estrutura neural. Este tipo de codificação também permite que novos genes sejam adicionados através dos operadores de mutação estrutural simplesmente anexando os novos genes ao final da lista. Embora codificações genéticas diretas não representem a realidade biológica, é suficientemente prática para muitos problemas onde o NEAT pode ser aplicado. Entretanto, atualmente existem trabalhos estendendo o NEAT para codificações indiretas, baseadas na embriologia (STANLEY; MIIKKULAINEN, 2003; STANLEY, 2007).

Para resolver o problema da permutação em genótipos de tamanhos variáveis, NEAT implementa um algoritmo inspirado no processo biológico de alinhamento de genes chamado de "sinapse". Este é o processo pelo qual acontece o cruzamento de genes, responsável pelo alinhamento de genes homólogos, independente da posição em que se encontra no cromossomo.

Para simular este processo, cada gene é identificado por um número único chamado de "registro histórico" (ou "número de inovação"). Um novo número é atribuído a cada novo gene que surge por mutação, daí o termo inovação. Portanto, independente do tamanho do genótipo ou do fenótipo (rede neural) resultante, genes homólogos são identificados unicamente pelo seu registro histórico. Em qualquer geração, os indivíduos que carregam genes com o mesmo registro histórico, compartilham da mesma estrutura (embora possivelmente com ganhos sinápticos diferentes), indicando um ancestral comum na sua origem. Desta forma é possível recombinar genótipos de quaisquer tamanhos (i.e., 
redes neurais de topologias arbitrárias) sem a necessidade de uma análise comparativa sofisticada, o que era necessário nos métodos de neuroevolução anteriores (YAO, 1993). A Figura 3.4 mostra um exemplo de genótipo e seu respectivo fenótipo (rede neural).
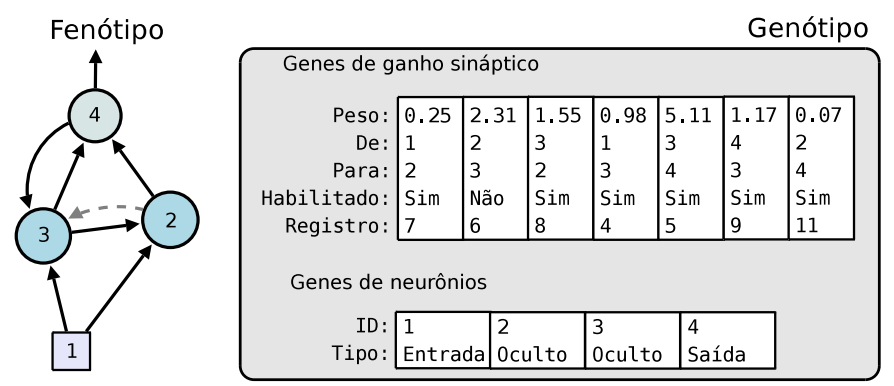

Figura 3.4: Exemplo de codificação genética no NEAT.

O genótipo consiste de duas listas de genes responsáveis pela codificação dos neurônios e das conexões entre eles. Os genes que expressam neurônios guardam informações sobre seu tipo: entrada, saída ou oculto, e um número único que o identifica. Os genes que expressam conexões sinápticas guardam informações sobre quais neurônios estão conectados por este gene, assim como seu ganho sináptico. Além do seu registro histórico, há também um "indicador", dizendo se o gene está ou não habilitado (isto é, se ele é expresso no fenótipo).

\subsubsection{Operadores Genéticos}

Assim como em outros modelos que empregam algoritmos genéticos, no NEAT temos o operador de mutação e de recombinação (crossover, mating). Como estamos trabalhando com genótipos de tamanho arbitrários, os operadores são um pouco mais sofisticados que os tradicionalmente implementados em simulações similares.

\subsubsection{Operador de Mutação}

Existem dois tipos básicos de mutação no NEAT: paramétrica e estrutural. A primeira é responsável por alterar os pesos nos genes que expressam os ganhos sinápticos da rede e a segunda permite a adição de novos neurônios e sinapses entre os neurônios existentes. Além disso, a mutação paramétrica pode também alterar completamente o ganho sináptico de uma conexão, assim como a estrutural pode também habilitar ou desabilitar um gene que expressa uma conexão. Não há mutação que remova um neurônio da rede e colabore na simplificação da estrutura. 
A Figura 3.5 mostra um exemplo de mutação estrutural com a adição de uma nova conexão e um novo neurônio.

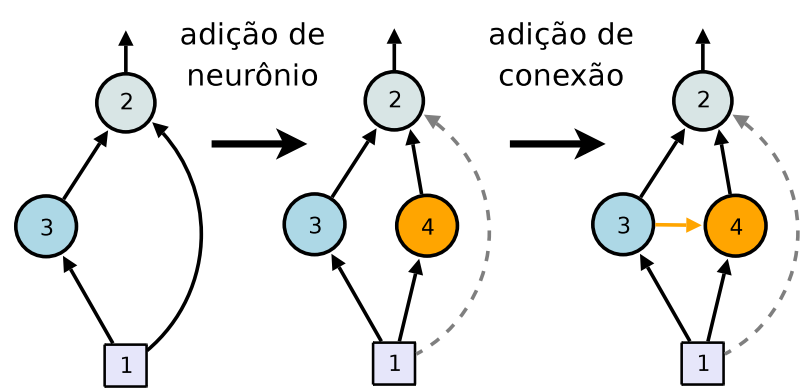

Figura 3.5: Exemplo de mutação estrutural.

A adição de uma nova conexão entre dois neurônios é feita adicionando um novo gene à lista de genes que expressam conexões, ligando dois neurônios previamente não conectados. A adição de um neurônio é um pouco mais elaborada. Novos neurônios só podem surgir entre conexões já existentes. Em outras palavras, ao adicionarmos um neurônio, é necessário criar mais dois genes que expressam conexão sináptica, conectando o novo neurônio aos outros dois que estavam anteriormente conectados. Além disso, a antiga conexão é desabilitada, como mostra a Figura 3.5.

Existem algumas dificuldades técnicas ao adicionarmos uma nova conexão na rede. A mutação não pode ser arbitrária no sentido de que quaisquer dois neurônios podem ser conectados, já que antes é preciso saber quais estão conectados entre si e se ainda há possibilidade de adicionarmos uma nova. Em topologias de redes recorrentes é relativamente simples calcular o número máximo de conexões sinápticas possíveis numa rede de $N$ neurônios. Sabendo este número e levando em consideração quantas conexões já existem, temos a quantidade possível de novas conexões válidas ${ }^{3}$.

A mutação paramétrica é similar à feita pelos métodos de neuroevolução anteriores. Um ganho sináptico pode ser alterado por um certo incremento ou pode ter seu valor alterado completamente por um novo número, geralmente com uma probabilidade menor. Entretanto, o NEAT admite que conexões mais antigas, no sentido do valor numérico de seu registro histórico, provavelmente estejam próximas de seu valor ótimo e portanto têm uma menor chance de sofrerem mutações. De forma oposta, novas conexões têm uma probabilidade maior de sofrerem mutações paramétricas. Essa hipótese é razoável já que genes que não tenham apresentado qualquer melhora durante as gerações serão eventualmente descartados pela seleção. Taxas dinâmicas de mutação

\footnotetext{
${ }^{3}$ Entende-se como conexão válida aquela que não tem como destino um sensor, já que este só recebe estímulos externos.
} 
já foram comparadas com métodos tradicionais, mostrando um aumento na eficiência do algoritmo (MICHALEWICZ, 1998).

\subsubsection{Operador de Recombinação}

No NEAT o operador de recombinação, ou cruzamento, precisa levar em consideração a topologia da rede para produzir um novo indivíduo. Como já foi dito, genótipos de tamanhos variáveis dificultam ainda mais o problema da permutação dos genes, tornando muitas vezes o operador de recombinação ineficaz. No entanto, no NEAT, esse problema é minimizado usando-se o registro histórico de cada gene. A Figura 3.6 ilustra o funcionamento do operador.

Após selecionarmos dois indivíduos da população (que na verdade pode ser uma subpopulação, ou espécie, e portanto os indivíduos compartilham algumas características genéticas) seus genes são alinhados e comparados pelo registro histórico de cada um deles. Podemos classificar os genes em três situações através do seu registro histórico. Genes que estão presentes no genótipo do pai e da mãe são chamados de homólogos, ou compatíveis. Isto é, representam a mesma sinapse na rede neural dos dois indivíduos, ainda que com pesos sinápticos diferentes. Genes que estão presentes em apenas um dos pais podem cair em duas situações: disjuntos ou excedidos. Os genes com registro histórico maior que aqueles presentes em apenas um dos pais são classificados como excedidos. Já os genes intermediários, também presentes num único indivíduo são chamados de disjuntos.

Genes compatíveis são herdados aleatoriamente para gerar o genótipo descendente enquanto que os genes disjuntos e excedidos são herdados apenas do indivíduo (pai ou mãe) cujo valor adaptativo é maior (Figura 3.6).

\subsubsection{Especiação}

Durante o processo evolutivo é bastante provável que, com a adição de novos genes ao cromossomo (através de mutações), o valor adaptativo do indivíduo seja inferior aos demais num primeiro momento, aumentando suas chances de ser eliminado da população na próxima geração. Não há como assegurar que novas mutações tragam vantagens adaptativas logo de início. Desta forma é necessário um método que nos permita separar os indivíduos por similaridade em sub-populações, permitindo a competição somente entre indivíduos geneticamente compatíveis, protegendo novas estruturas e dando-lhes algum tempo para se adaptarem. 

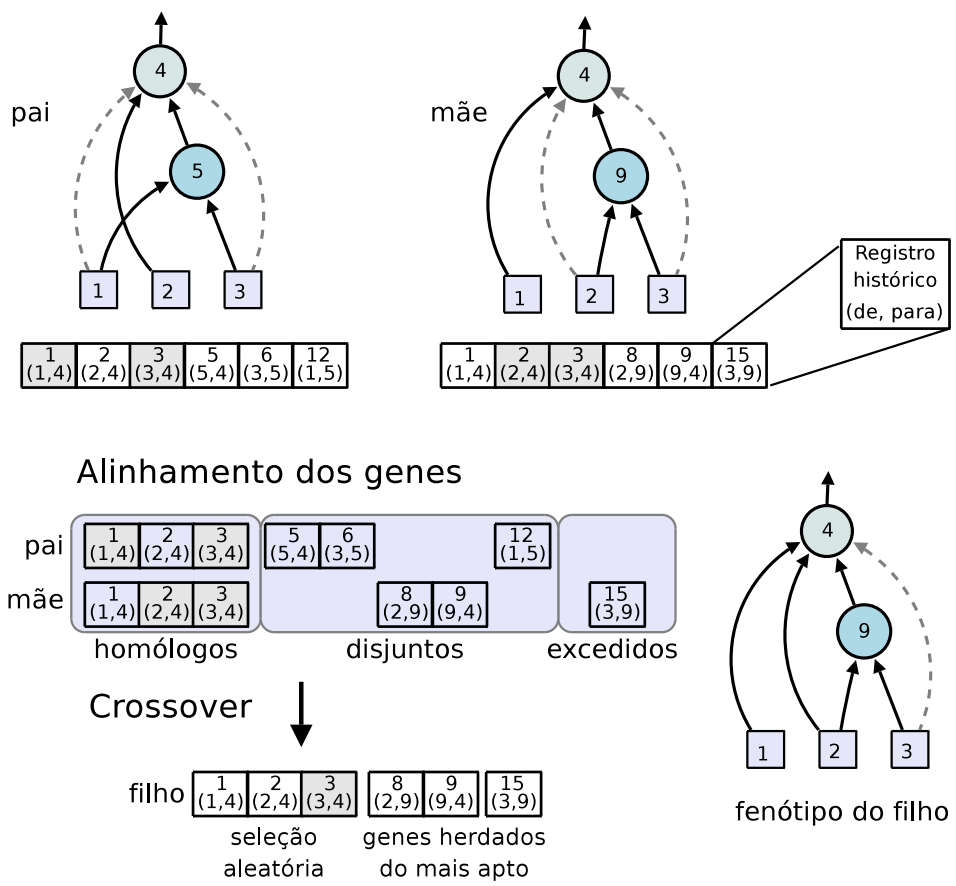

Figura 3.6: Operador de recombinação.

A especiação no NEAT é feita usando os registros históricos que cada indivíduo carrega em seus genes, tornando possível separar a população por similaridade topológica. A distância $\delta$ entre dois indivíduos é dada pela combinação linear do número de genes excedidos $(E)$, disjuntos $(D)$ e pela média da diferença dos ganhos sinápticos entre os genes homólogos $(\bar{W})$ (Eq. 3.1).

$$
\delta=\frac{c_{1}}{N} E+\frac{c_{2}}{N} D+c_{3} \bar{W}
$$

onde os coeficientes $c_{1}, c_{2}$ e $c_{3}$ ponderam a importância das diferenças entre dois genótipos (e conseqüentemente a topologia da rede neural) e $N$ é o número de genes do maior genótipo da população. Geralmente os parâmetros são escolhidos de forma que a distância é menor quanto maior for o número de genes homólogos e maior caso contrário.

Cada indivíduo é comparado com um membro representante de cada espécie. Se a distância entre ambos for inferior a um limiar de compatibilidade $\left(\delta_{t}\right)$, este indivíduo é adicionado a esta espécie. Pode acontecer do indivíduo não ser compatível com nenhum outro da população, neste caso é criada uma nova espécie para comportá-lo.

O mecanismo de reprodução empregado é conhecido por Explicit Fitness Sharing (MAHFOUD, 1996), onde indivíduos de uma mesma espécie compartilham seus valores adaptativos, prevenindo que qualquer uma das espécies cresça e tome toda a população. 
Cada indivíduo $i$ de cada espécie tem seu valor adaptativo $\left(f_{i}\right)$ ajustado de acordo com sua distância $\delta$ em relação a todos os outros organismos $(j)$ da população:

$$
f_{i}^{\prime}=\frac{f_{i}}{\sum_{j=1}^{n} \operatorname{sh}(\delta(i, j))}
$$

A função $\operatorname{sh}(\cdot)$ (sharing function) é definida da seguinte maneira: se $\delta(i, j)>\delta_{t}$, então $\operatorname{sh}(\cdot)=0$, caso contrário $\operatorname{sh}(\cdot)=1$. Desta forma o denominador da equação 3.2 representa o total de indivíduos da qual o organismo $i$ faz parte.

Cada espécie deve produzir um número fixo de indivíduos para a próxima geração. Este número é proporcional à soma dos valores adaptativos de seus membros e é dado por:

$$
n_{k}=\frac{\bar{F}_{k}}{\bar{F}_{\text {total }}}|P|
$$

sendo $\bar{F}_{k}$ o valor adaptativo médio da espécie $k,|P|$ o tamanho da população total e

$\bar{F}_{\text {total }}=\sum_{k} \bar{F}_{k}$ o valor adaptativo médio de todas as espécies. A partir deste ponto é feita a seleção dos indivíduos que irão se reproduzir para gerar a nova população.

\subsubsection{Método de Seleção}

A seleção ocorre de maneira independente em cada espécie. Pode-se imaginar que para cada espécie o NEAT se reduz a um algoritmo genético comum já que a seleção e a reprodução ocorrem de forma paralela para cada espécie. Como vimos na seção 2.2.4, existem diversos tipos de seleção num algoritmo genético. No NEAT o método de seleção usado difere um pouco dos demais. Todos os indivíduos de cada espécie são ordenados pelo seu valor adaptativo. O melhor de cada espécie é mantido para a próxima geração e então passa a ser o representante de tal espécie. Em seguida, uma porcentagem é escolhida para reprodução enquanto que os demais são descartados.

A reprodução acontece selecionando aleatoriamente dois pais dentre os indivíduos restantes para gerar um único filho. O processo se repete até que a quantidade de novos indivíduos seja alcançada, o que pode diferir entre as espécies.

\subsubsection{Complexificação}

Uma questão pouco levada em consideração nos primeiros métodos de neuroevolução está em como inicializar a primeira geração, isto é, como deve ser o genótipo dos indivíduos da população (STANLEY, 2004). Normalmente era utilizado o fator aleatório e cada 
indivíduo tinha sua topologia representada de forma arbitrária, logo na primeira geração (Figura 3.7).

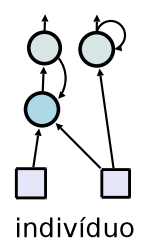

1

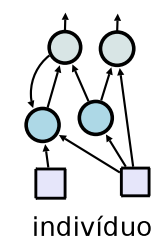

2

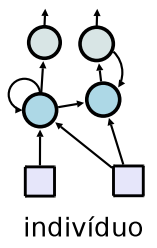

3

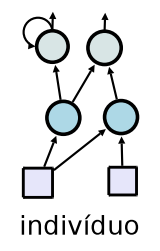

4

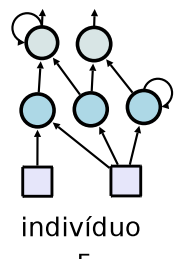

5

Figura 3.7: RNAs aleatórias na primeira geração.

Se imaginarmos que, ao acaso, a primeira topologia usada estivesse próxima do ponto ideal, então a convergência do algoritmo genético seria rápida e em poucas gerações a solução seria alcançada. Mas neste espaço discreto, onde cada ponto representa um tipo particular de topologia, seria muito improvável encontrá-lo ao acaso. Portanto, iniciar o espaço de busca a partir de um ponto qualquer não traz vantagens do ponto de vista matemático.

Por este motivo, no NEAT, a primeira geração de indivíduos carrega em seus genes a codificação da menor topologia possível, isto é, todas as entradas sensoriais estão conectadas diretamente aos atuadores (Figura 3.8). Desta forma, o espaço de busca é minimizado e com a adição de novos genes através de mutações aleatórias ocorre o que denominamos na biologia de complexificação.

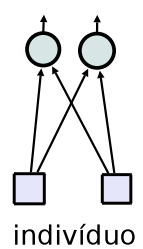

1

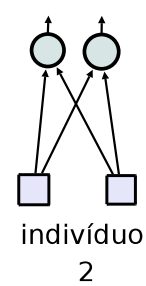

2

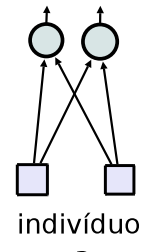

3

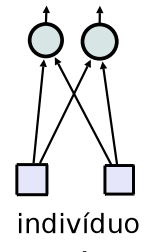

4

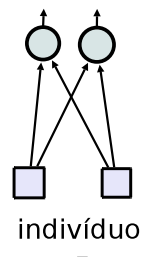

5

Figura 3.8: Mínima topologia inicial possível.

\subsection{Observações Finais}

Dentre os diversos métodos de neuroevolução, o NEAT apresenta os melhores resultados em testes comparativos na resolução de problemas clássicos como XOR e pêndulo invertido (STANLEY, 2004). No entanto, a metodologia usada na comparação entre diversos métodos é dificultada pela falta de um padrão nos tipos de experimentos que de fato demonstre a superioridade de um método em relação a outro. O problema fica 
ainda maior quando estamos interessados em simulações de Vida Artificial, já que mesmo os experimentos padrões como esquiva de obstáculos (em Robótica Evolutiva) ou busca por alimento, exigem descrições detalhadas de diversas variáveis como os tipos de sensores e atuadores usados e em qual ambiente virtual ou físico os experimentos foram realizados.

Por outro lado, um método de neuroevolução eficiente torna-se bastante atrativo em experimentos de Vida Artificial como descrito por Dyer (1994), e embora algumas investigações neste sentido já tenham sido realizadas, pouca atenção é dada para a descrição detalhada do método de neuroevolução usado e como ele se compara com os demais. Na falta destes detalhes, o NEAT apresenta uma excelente alternativa por ter sido explorado em diversas áreas. 


\section{Neuroevolução em Vida Artificial}

Geralmente, em trabalhos de vida artificial que envolvam neuroevolução, os objetivos estão em testar hipóteses a respeito de algum fenômeno natural, como atenção seletiva (SILVA, 2005), ou demonstrar a viabilidade de algum conceito (SIMS, 1994b). Há também interesses de caráter aplicado, como desenvolvimento de controladores para robôs (NOLFI; FLOREANO, 2000), aprendizado (YAO, 1993) e aplicação em jogos eletrônicos (STANLEY; BRYANT; MIIKKULAINEN, 2005). Embora em diferentes áreas e com propósitos diversos, muitos destes problemas compartilham certas características. Mesmo estudando atenção seletiva através de simulações, este tipo de experimento requer o uso de redes neurais para o controle do organismo. De maneira similar, o mesmo acontece em Robótica Evolutiva e ambos muitas vezes podem se enquadrar na área de aprendizado evolucionário ou por reforço, por exemplo.

Até o momento vimos parte da teoria de Algoritmos Genéticos e Redes Neurais Artificiais combinados de tal forma que seja possível tirar proveito de ambos, mas sem nos preocuparmos com o campo de aplicação. Este capítulo descreve alguns trabalhos clássicos que fazem uso de técnicas de neuroevolução, em geral desenvolvidas para experimentos específicos. Outro ponto importante em tais trabalhos está na visualização, em tempo-real ou não, da simulação, mostrando a necessidade da representação gráfica.

\subsection{Histórico}

Embora os primeiros trabalhos em Redes Neurais e Algoritmos Genéticos sejam, respectivamente, da década de 1950 e 1970, a possibilidade de simular a evolução do sistema nervoso em experimentos de Vida Artificial surgiu recentemente, em meados da década de 1990, graças ao avanço de técnicas capazes de combiná-los de forma eficiente (STANLEY; MitKKULAINEN, 2002). Outra contribuição veio do aumento na disponibilidade de máquinas para computação intensiva. 
Esta seção faz um rápido levantamento histórico do cenário que culminou na realização de diversos experimentos na década que ficou conhecida pelo estabelecimento do que hoje chamamos de Nova Inteligência Artificial (PFEIFER; SCHEIER, 1999).

\subsubsection{Veículos de Braitenberg}

Um pouco antes de Brooks (1986) sugerir sua nova arquitetura para robótica reativa, em 1984 o neurofisiologista Valentino Braitenberg publicou o livro Vehicles: Experiments in Synthetic Psychology (BRAITENBERG, 1984), que serviria de inspiração para uma nova abordagem em IA que começou a ganhar atenção na década seguinte. Embora a obra não trate de nenhum método de neuroevolução, as primeiras idéias para abordar efetivamente a inteligência através de paradigmas biológicos estavam efetivamente se estabelecendo.

Braitenberg (1984) propôs uma série de experimentos mentais onde pequenos veículos dotados de duas rodas em suas laterais fossem controlados simplesmente pelo que seus sensores captassem no ambiente. As conexões entre os sensores e os atuadores poderiam ser feitas por fios elétricos ou qualquer outro dispositivo eletrônico capaz de ler os dados recebidos pelos sensores e enviar impulsos para os motores. Diferentes veículos deste tipo foram descritos em seu trabalho, e dois exemplos são apresentados na Figura 4.1. Os veículos eram então colocados sob uma mesa e, conforme a configuração interna de cada um deles, podiam exibir comportamentos diversos, como por exemplo, aproximar-se de fontes de luz e seguir ou fugir de um outro veículo.

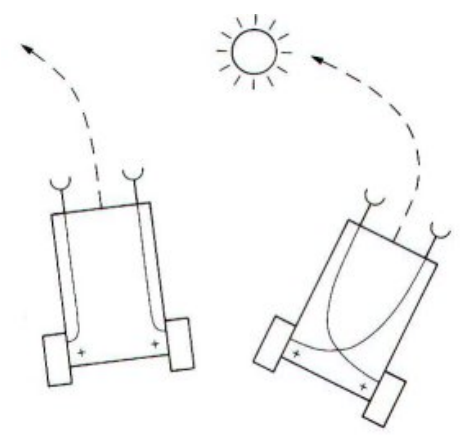

Figura 4.1: Exemplo de veículos de Braitenberg (1984).

Uma das principais contribuições no trabalho de Braitenberg é a demonstração de que, para o observador externo que desconheça a arquitetura interna do veículo, parece existir intenção no comportamento. Outro ponto importante, que serviria de inspiração para a Robótica Evolutiva (próxima subseção), é a menção de alguns princípios evolutivos na construção de controladores, similar ao paradigma Darwiniano. Assim como os experimentos mentais de Einstein foram importantes para o desenvolvimento da física, as 
idéias de Braitenberg resultaram num efeito similar na sua área. Um simples experimento, mas que indiretamente sugeria a idéia de neuroevolução, é descrito a seguir.

Imagine que descartemos os veículos que caíssem da mesa e vamos nos concentrar naqueles que exibem algum comportamento que os faça permanecer sobre a mesa por um certo período de tempo. Então escolhemos um destes veículos e o copiamos. Como a cópia é manual, é necessário construir um outro veículo usando a mesma configuração do veículo selecionado e colocá-lo de volta na mesa. Seguindo este processo, se quisermos manter um número constante de veículos sobre a mesa, é necessário copiar um veículo novo cada vez que um deles caia. Durante o processo de cópia manual, é inevitável que cometeremos erros (por exemplo, inverter a polaridade de uma conexão elétrica, usar um resistor diferente, dentre outros). Estas cópias levemente modificadas podem ter a "sorte" de permanecer sob a mesa por mais tempo que outros veículos, aumentando suas possibilidades de ser escolhido para cópia novamente, enquanto que as versões cujas modificações não tragam qualquer vantagem para o veículo, serão descartadas ao cair da mesa. Nessa analogia, fica claro como obter novos comportamentos e aptidões através de um processo seletivo de cópia com erros aleatórios sem a intervenção de um designer. Este é justamente o principal conceito Darwiniano: o processo de escolher um veículo qualquer que ficou na mesa por um certo período de tempo é análogo à reprodução assexuada. As cópias que fizemos destes veículos podem ser considerada como mutações aleatórias e o ato de "cair da mesa" representa a seleção natural. Simples o suficiente para ser compreendido num único parágrafo ${ }^{1}$, permitindo ser facilmente adaptado num modelo que possa exibir características semelhantes (HOLLAND, 2001).

Como veremos na próxima seção, parte destas idéias serviram para implementar e desenvolver controladores neurais para robôs, através de evolução artificial, estabelecendo a abordagem bottom-up de forma definitiva na década seguinte.

\subsubsection{Abordagem Animat}

O termo animat (de animais artificiais), cunhado por Wilson (1991), representa uma nova proposta para investigar a inteligência através de modelos "complexos" de simples formas de vida (como insetos), em contraposição ao uso de modelos "simples" para aproximar comportamentos de alto-nível. A motivação é principalmente biológica, e serviu como crítica à metodologia clássica na IA tradicional (VAARIO, 1994; FRANKLIN, 1997; PFEIFER;

\footnotetext{
${ }^{1}$ Dennett (1996) sugere que o Darwinismo, de tão simples que é, foi capaz de criar concepções totalmente contrárias ao que ele realmente representa. Na sua simplicidade é que residem os erros de interpretação.
} 
SCHEIER, 1999). A hipótese central na abordagem de Wilson (1991) sustenta que, através de simulações utilizando como modelo um ambiente artificial, com o qual o animat possa interagir, seria possível conseguir níveis de sofisticação comportamental cada vez maiores, eventualmente podendo alcançar o nível de inteligência humana.

A hipótese é baseada numa simples observação de sistemas naturais: a necessidade de sobrevivência. Esta "necessidade" seria o motivo de toda a diversidade de comportamentos existentes na natureza, já que, para sobreviver, é necessário cumprir alguns critérios (como busca de alimento, por exemplo). Wilson (1991) divide a abordagem em dois subproblemas gerais, o primeiro se preocupa com o ambiente da simulação, enquanto que a segundo trata do tipo de arquitetura utilizada pelo animat para interagir com o ambiente. Os veículos de Braitenberg podem ser considerados como versões de um animat, por exemplo.

De forma geral, grande parte dos trabalhos em Vida Artificial se preocupa principalmente com o tipo de arquitetura. Um particular ambiente é escolhido, acreditando ser suficientemente representativo para o interesse do estudo, e em seguida os esforços se concentram na melhor arquitetura para este particular ambiente. No contexto deste trabalho, a arquitetura a qual Wilson (1991) se refere pode ser representada pelo NEAT, como um mecanismo de evolução artificial onde o comportamento do animat possa ser controlado por um modelo de sistema nervoso. O simulador para o problema do ambiente será tratado mais a frente. Neste momento é importante destacar que o trabalho de Braitenberg (1984) e Wilson (1991) serviram como base teórica para os desenvolvimentos a seguir.

\subsubsection{Robótica Evolutiva}

Uma das áreas que aplicam o conceito de animats é a Robótica Evolutiva (NOLFI; FLOREANO, 2000). Historicamente surgiu na Europa por volta de 1994, onde o interesse era obter configurações de pesos sinápticos em redes neurais para controlar pequenos robôs em determinadas tarefas (HARVEY; HUSBANDS; CLIFF, 1994; FLOREANO; MONDADA, 1994).

Os primeiros trabalhos serviram como prova conceitual da possibilidade de realizar simples tarefas apenas especificando o que deveria ser feito, mas não como. A função de avaliação é escolhida cuidadosamente para que não seja muito restritiva ou genérica, a ponto de não permitir encontrar uma solução. De forma similar, o ambiente também precisaria ser suficientemente simples para que a solução fosse encontrada em tempo hábil. 
Os experimentos eram realizados utilizando robôs físicos, não simuladores, portanto o tempo ficava restrito à limitações físicas dos robôs.

Independente de estarmos falando de robôs físicos ou virtuais (também conhecido por softbots), os conceitos fundamentais permanecem os mesmos. Basicamente o robô possui um conjunto de sensores para perceber o ambiente e um conjunto de efetores para interagir com o ambiente (não necessariamente modificando-o). Um computador controla a população de robôs, alternando entre cada indivíduo durante o processo de avaliação da tarefa. A Figura 4.2 ilustra o processo.

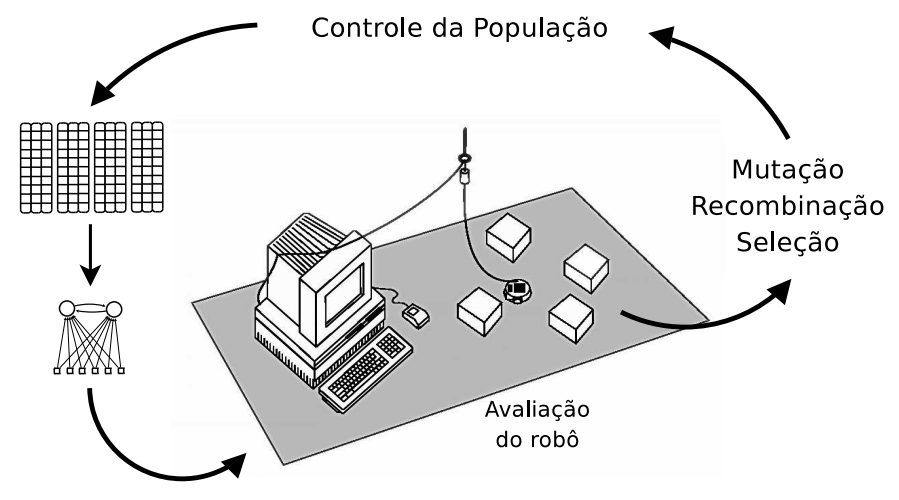

Figura 4.2: Ambiente de simulação em Robótica Evolutiva. Adaptado de (NOLFI; FLOREANO, 2000).

No contexto de robótica evolutiva, geralmente estamos interessados na evolução do sistema de controle, mas há casos em que a morfologia também passa pelo mesmo processo de adaptação. Embora possa ser denominada como uma sub-área de Vida Artificial, as pesquisas em Robótica Evolutiva seguiram um caminho próprio, e recentemente foi considerada como uma nova ferramenta para estudar cognição (HARVEY et al., 2005).

\subsection{Trabalhos Anteriores de Vida Artificial}

Esta seção descreve três trabalhos em Vida Artificial que seguem a abordagem animat. Embora com objetivos ligeiramente diferentes, todos utilizam de algum modo evolução de topologias para controlar organismos artificiais e um ambiente virtual.

\subsubsection{Evolução Morfológica}

Um dos trabalhos mais conhecidos, tanto na comunidade de Computação Gráfica quanto em Vida Artificial, são as criaturas virtuais de Sims (1994b). Organismos constituídos 
de pequenos blocos, controlados por um modelo similar a redes neurais, desenvolvem comportamentos de competição num ambiente virtual 3D para atingirem tarefas préestabelecidas. O objetivo do trabalho não está somente em estudar propriedades emergentes, mas em compreender e explorar as conseqüencias ao reunir um conjunto de conceitos simples, porém importantes, como evolução de redes neurais, sensores e a própria morfologia, num ambiente simulando a seleção natural.

O experimento inicializa com indivíduos (fenótipos) a partir de genótipos criados aleatoriamente. Numa primeira fase os fenótipos passam por um teste seletivo, eliminando criaturas "inviáveis" (com partes auto-penetrantes, por exemplo). A grande contribuição de Sims está no método utilizado para especificar o genótipo das criaturas, flexível para permitir praticamente infinitas possibilidades de configuração. Uma estrutura em grafo direcionado define como construir o genótipo através de regras recursivas (Figura 4.3).

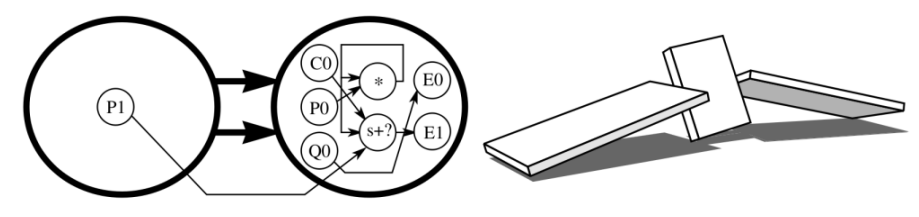

Figura 4.3: Exemplo de genótipo (esquerda) e o fenótipo resultante (SIMS, 1994b).

Os nós do grafo representam partes rígidas do corpo da criatura e as arestas definem como elas são conectadas. Além disso, os nós contêm atributos como dimensão (tamanho das partes), tipo de conexão (rígida ou não) e tipo de neurônio, que diferente dos modelos tradicionais, são compostos de funções específicas como seno, coseno, dentre outras. Algumas funções têm a propriedade de manter um estado interno, servindo de memória dos passos anteriores, podendo apresentar dinâmica mesmo na ausência de entradas sensoriais (parecido com as CTRNNs da Seção 2.1.5). As criaturas podem ter três tipos de sensores, ligados aos membros do corpo. Um sensor pode detectar o ângulo de inclinação de uma junção, enquanto que outro detecta contato direto. Em alguns experimentos as criaturas tinham também um sensor sensível à luz. Os efetores recebem conexões sinápticas de outros neurônios ou diretamente dos sensores. Sua saída determina a força aplicada (torque) nas juntas.

Diversos experimentos foram realizados, cada um com o objetivo de conseguir um determinado comportamento, como caminhar, nadar, pular e seguir um objeto. Num segundo trabalho (SIMS, 1994a) foi explorada a co-evolução por competição numa tarefa cujo objetivo era agarrar um cubo disposto entre duas criaturas com morfologias e sistemas neurais distintos. O tipo de morfologia obtida para nadar ou caminhar lembram 
criaturas reais, com membros simétricos capazes de se moverem ritmicamente, ou ainda estruturas em forma de cauda, exigindo a coordenação de todas as partes (Figura 4.4). Nos experimentos de co-evolução criaturas similares parecem exibir "vontade própria" na captura do objeto.
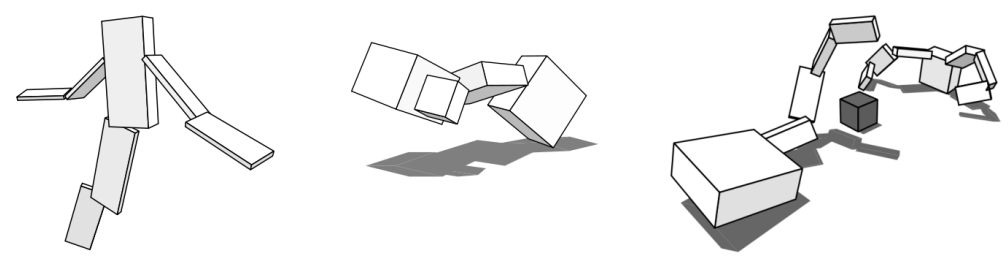

Figura 4.4: Exemplo de criaturas obtidas para nadar (esquerda), caminhar (centro) e agarrar um cubo (SIMS, 1994a).

Estes resultados enfatizam as observações de Wilson (1991) sobre a questão de mensurar a capacidade de um animat em manter seu nível de "necessidade" acima de um limiar, garantindo sua sobrevivência. A noção intuitiva que temos sobre inteligência poderia ser traduzida num número representando o "nível de necessidade" alcançado pela criatura. O trabalho de Sims (1994b) mostra um interessante balanço entre o problema de se representar o ambiente virtual e a arquitetura utilizada para controlar os organismos que nele se situam.

\subsubsection{Polyworld}

Outro trabalho, com foco principalmente na evolução da inteligência em vida artificial, foi apresentado por Yaeger (1994) no simulador de ecologia artificial chamado Polyworld. O ambiente no simulador era composto de um plano, onde todos os organismos podiam interagir entre si, com alimentos (dispostos aleatoriamente) e com obstáculos. Embora o ambiente tenha uma representação em três dimensões, os organismos podiam apenas se mover num único plano (Figura 4.5).

O algoritmo genético no Polyworld é usado de forma contínua, isto é, não há uma separação clara entre as gerações. Os organismos se reproduzem conforme se cruzam pelo ambiente, condicionados às suas "vontades" (para reproduzir é necessário que os dois optem por este comportamento). Neste tipo de simulação, o número de indivíduos na população é variável. Para manter a simulação tratável computacionalmente, o tamanho máximo da população precisa ser definido como parâmetro de configuração do experimento. Os obstáculos (definidos como paredes no ambiente) podem ser definidos de forma arbitrária. O palco da simulação podia ser tratado de três formas: possuindo 


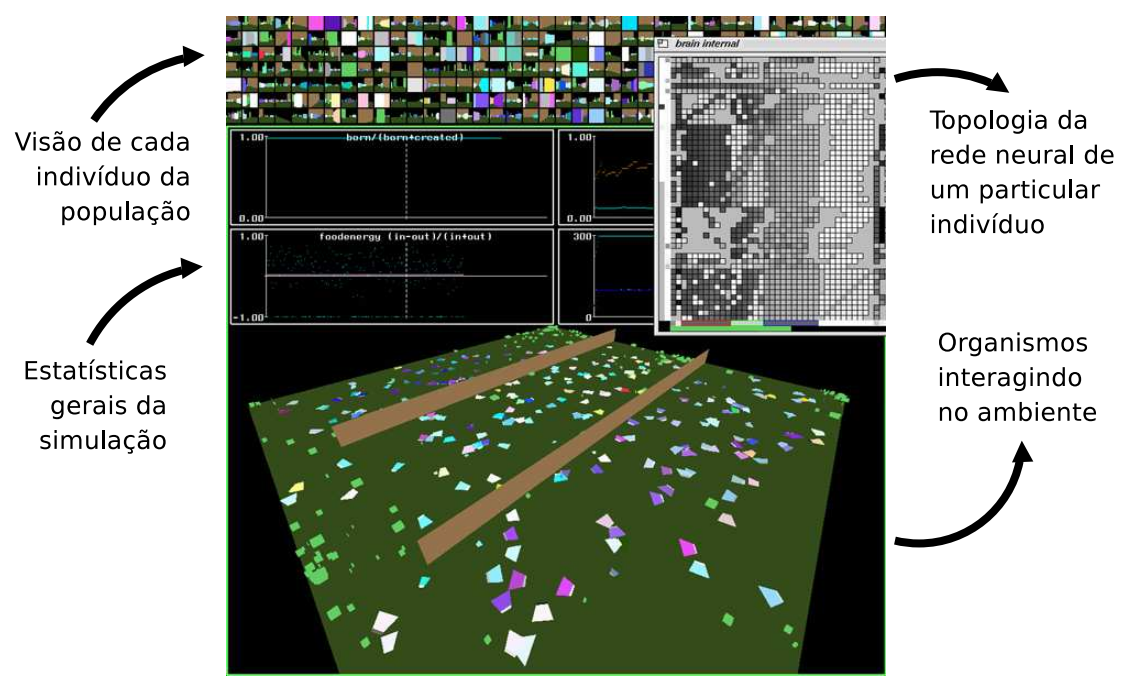

Figura 4.5: Ambiente Polyworld (YAEGER, 1994).

obstáculos (limites externos como paredes), sem limites (forma toroidal ou esférica, e portanto sem limitadores) ou ainda apenas como um plano (de modo que ao ultrapassar os limites os organismos saiam da simulação).

O simulador levava em consideração certas características fisiológicas, como o consumo de energia em função de atividade neural e locomoção motora. O nível de energia era abastecido consumindo alimentos dispostos no ambiente (a única métrica para o valor adaptativo do organismo). A rede neural recebia entradas do sistema de visão do organismo, além do valor normalizado da sua quantia interna de energia e mais um valor aleatório. A visão era decomposta nas cores primárias e tratada por um grupo específico de neurônios (a quantidade de neurônios para cada cor pode ser diferente para cada organismo, permitindo a adaptação para certas características do ambiente). A saída da rede era composta por sete neurônios, cada uma representando um comportamento primitivo: comer, cruzar, lutar, mover, virar, focar e iluminar (estes dois últimos controlam o sistema de visão). Na época da publicação, em 1994, o simulador era executado numa Silicon Graphics Iris 4D/240-GTX. Com uma população de 300 organismos, com aproximadamente 200 neurônios cada, levando cada passo da simulação 13 segundos para ser completado. Levando em consideração uma média de 500 passos para cada organismo, era necessário por volta de uma semana para simular 500 gerações.

Um dos resultados importantes das simulações no Polyworld está na emergência de espécies (grupo de indivíduos com comportamentos similares). Sem nenhuma restrição manual, grupos de organismos similares surgem ao longo das gerações. Embora o problema da especiação na biologia, e por conseqüência em vida artificial, seja de extrema 
importância, este tópico não foi amplamente discutido e analisado neste trabalho.

\subsubsection{Geb}

Mais recentemente, seguindo basicamente a mesma linha do Polyworld, um outro simulador (Geb) foi desenvolvido para investigar a emergência de comportamento adaptativo, escrito por Channon e Damper (1998). Diferente do Polyworld, no Geb os indivíduos não aprendem durante seu tempo de vida, evitando o efeito Baldwin nas análises (CHANNON, 2001, 2003).

No simulador Geb o ambiente virtual tem uma geometria toroidal e os organismos se movem num plano de duas dimensões. Para simplificar a simulação, o ambiente é dividido numa grade de $20 \times 20$ e apenas um único organismo pode ocupar cada célula ao mesmo tempo, cada um destes controlados por redes neurais que podem assumir topologias arbitrárias, também sem restrições de tamanho (Figura 4.6 (a)). No Geb a estrutura da rede neural é representada de forma indireta, utilizando um sistema-L de desenvolvimento. Desta forma cada cromossomo carrega instruções de como construir a rede neural, mas não a estrutura em si (similar à abordagem de Sims (1994b)). O modelo de neurônio utilizado foi baseado na versão de McCulloch-Pitts. Cada neurônio recebe sinapses excitatórias $(+1)$ e inibitórias $(-1)$. A saída, diferente dos modelos tradicionais, pode resultar em duas ativações, conforme mostra a Figura 4.6 (b).

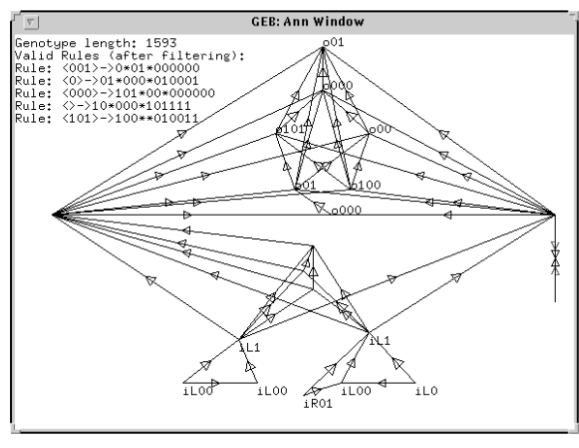

(a)

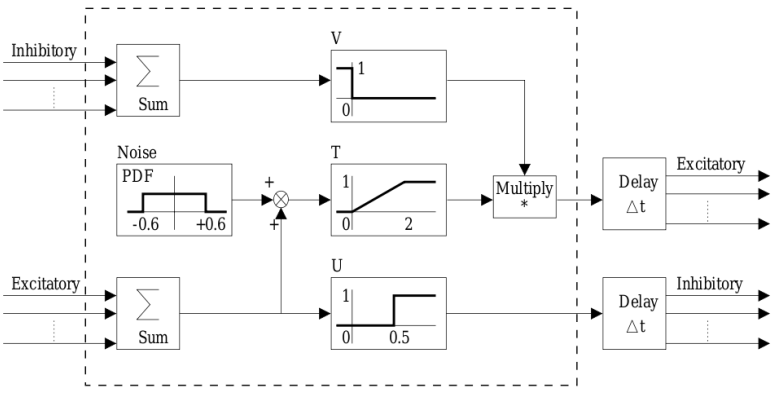

(b)

Figura 4.6: (a) Rede neural de um único indivíduo; (b) Modelo de neurônio utilizado no Geb (CHANNON; DAMPER, 1998).

Assim como no Polyworld, o organismo tem um conjunto possível de ações a realizar: reproduzir e lutar (com o organismo situado na frente), virar sentido horário e anti-horário e mover-se para frente (caso não exista obstáculo). Os sensores detectam a presença de outros organismos ou alimentos próximos (nas células adjacentes). Com o auxílio de técnicas estatísticas, é possível medir a "taxa de evolução" segundo alguns critérios 
baseados na teoria da informação e complexidade de Kolmogorov. Análises similares foram feitas por Yaeger (1994) no Polyworld, mostrando uma preocupação com os aspectos teóricos neste tipo de simulação. Num dos trabalhos de co-autoria, Miconi e Channon (2006) mostraram uma replicação do trabalho de Sims (1994b), afirmando ter obtidos os mesmos resultados utilizando um modelo mais genérico, com o uso de neurônios do tipo McCulloch-Pitts. A crítica principal está na falta de certos detalhes no trabalho de Sims (1994b) que dificultam a replicação.

\subsection{Conclusão}

O propósito deste Capítulo foi de mostrar o desenvolvimento histórico da aplicação de algoritmos genéticos e redes neurais em problemas clássicos de Vida Artificial. É evidente que todos eles compartilham semelhanças, principalmente na evolução dos organismos controlados por redes neurais e nos ambientes nos quais estão inseridos. O NEAT, como algoritmo de neuroevolução bem estabelecido, pode ser facilmente adequado em experimentos similares sem a preocupação de se desenvolver um novo método que lide com problemas já investigados. O mesmo vale para o ambiente virtual, que envolve diretamente conhecimento de computação gráfica e simulação de física. O Capítulo seguinte trata do uso de simuladores de propósito geral, que podem ser combinados com o NEAT para a realização de experimentos como os descritos aqui. 


\section{Simuladores e Implementação}

Este capítulo propõe uma plataforma para desenvolvimento de experimentos em Vida Artificial onde o interesse se concentra principalmente em estudar comportamento adaptativo numa população de indivíduos controlados por redes neurais, situados num ambiente virtual. A primeira seção consiste na descrição de dois simuladores que servem ao propósito de criar um cenário virtual, permitindo a interação entre os indivíduos e o ambiente. Em seguida é descrito o desenvolvimento do projeto que resultou na implementação do NEAT, como uma biblioteca que pode ser facilmente estendida e, principalmente, usada em conjunto com um simulador de propósito geral, permitindo que experimentos similares àqueles descritos no capítulo anterior, sejam realizados sem a necessidade de escrever completamente toda a plataforma exigida neste tipo de simulação.

\subsection{Simuladores de Ambientes Virtuais}

Como vimos na seção 4.2 do capítulo anterior, trabalhos como o de Karl Sims, Polyworld e Geb precisam considerar o tipo de ambiente a ser construído (com variados graus de realismo e complexidade). Diversas propostas foram feitas ao longo dos anos, algumas de caráter mais específico, como os famosos simuladores para robótica, Player, Gazebo e Stage (GERKEY; VAUGHAN; HOWARD, 2003), enquanto outras procuraram seguir uma linha mais abrangente como StarLogo e Swarm (KLEIN, 2002).

O desenvolvimento necessário para a criação de tal ambiente envolve conhecimentos avançados de programação e computação gráfica e pode consumir completamente o tempo disponível, indo além dos objetivos primários do experimento. Além disto, tais aplicações podem ser suficientemente complicadas para escrever simulações. Diante das alternativas, este trabalho se concentra num simulador relativamente recente, conhecido por Breve, e descrito a seguir. 


\subsubsection{Breve}

Esta seção descreve um simulador multi-agentes desenvolvido para realização de experimentos em Vida Artificial, chamado Breve ${ }^{1}$. O projeto teve início a partir da tese de doutorado de Klein (2002) e sua proposta era criar um simulador 3D de uso simples, mas suficientemente genérico para aplicações de vida artificial. Este simulador incorpora assim tanto módulos para tratar dos aspectos visuais da simulação (visualização) como dos seus aspectos físicos (simulador físico). E para tal faz uso de ferramentas já desenvolvidas, que são apresentadas a seguir.

\subsubsection{Simulação de Física}

Em algumas situações podemos estar interessados em que o ambiente virtual se comporte de uma maneira fisicamente realista, além de detecção de colisão, casos em que a força da gravidade, massa, atrito entre objetos articulados etc, requerem o uso do que denominamos simuladores de física. Basicamente, tais simuladores implementam as equações da mecânica clássica, onde cada objeto do cenário tem sua própria massa e extensão, estando sujeito às leis físicas, como ação e reação ou inércia.

O Breve foi desenvolvido usando as bibliotecas de um conhecido simulador de física, bastante usado em projetos de jogos eletrônicos, o ODE (Open Dynamics Engine (SMITH, 2008)). Escrito em C/C++, o ODE se preocupa apenas com a solução das equações diferenciais da física, não fornecendo qualquer visualização da simulação. Por exemplo, num experimento típico da queda livre de um objeto, a saída do programa será o vetor da posição e velocidade do objeto a cada instante de tempo. Por questões de estabilidade e velocidade, o ODE resolve as equações diferenciais pelo método de Euler, e portanto não é indicado para uso em trabalhos de interesse industrial, onde a precisão tornase fundamental. No entanto, para o propósito deste trabalho, parece atender bem as expectativas.

Alguns problemas podem exigir o uso de diversos objetos conectados através de articulações, formando um único corpo. Além das criaturas de Sims, um braço mecânico ou um robô composto de diversas partes são exemplos típicos. A biblioteca ODE fornece as principais articulações físicas possíveis e portanto, também são acessíveis a partir do Breve (Figura 5.1).

Uma enorme gama de construções podem ser obtidas a partir destas articulações,

\footnotetext{
${ }^{1}$ Multi-plataforma, com os fontes disponíveis sob licença GPL em: spiderland.org (KLEIN, 2002)
} 

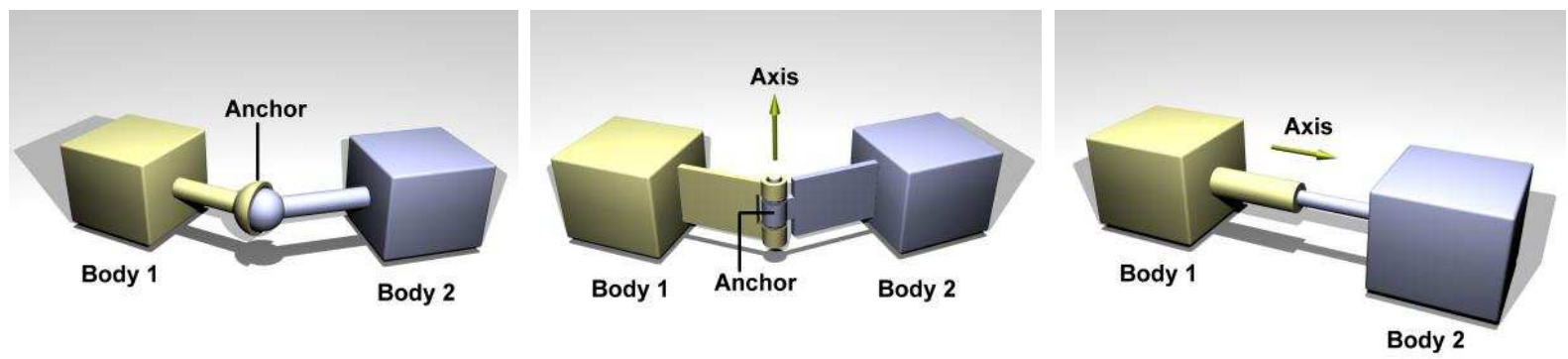

Figura 5.1: Tipos de articulações disponíveis no Breve, através do ODE, para corpos compostos de vários objetos.

e servem exatamente o propósito de simulações como aquelas de Sims (1994b) ou as idealizadas por Braitenberg (1984).

\subsubsection{Visualização $3 \mathrm{D}$}

Apenas com o simulador de física, teríamos apenas como resposta do experimento um grande conjunto de vetores, descrevendo o atual estado do ambiente. A visualização de como estes objetos estão dispostos e interagindo no ambiente seria útil por diversos motivos, como depurar o experimento e observar visualmente o resultado final da simulação. Para tal o Breve fornece, através da biblioteca gráfica OpenGL, a visualização 3D em tempo-real do experimento, sem a necessidade de se preocupar em implementar rotinas gráficas de baixo nível.
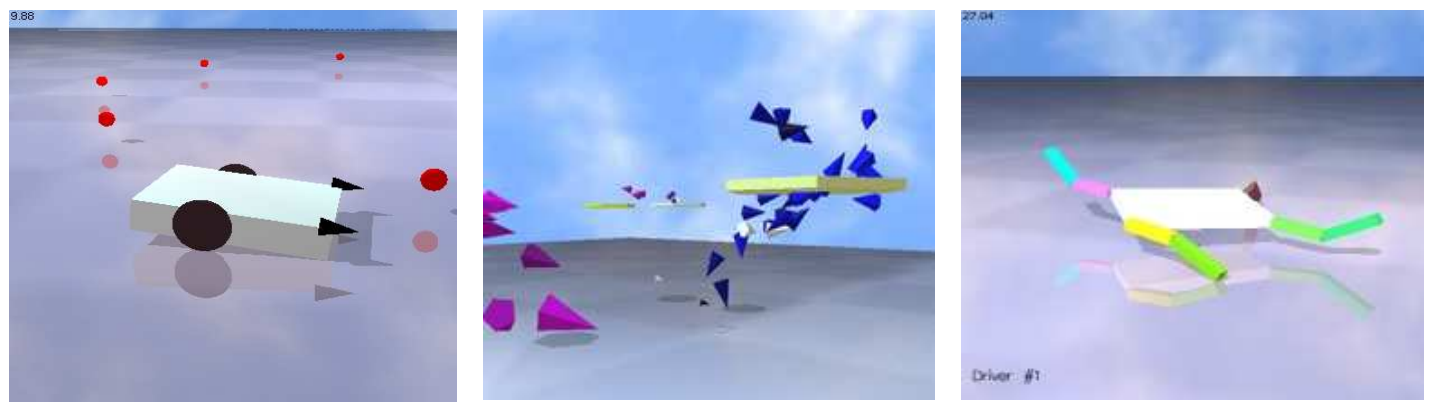

Figura 5.2: Visualização de alguns experimentos realizados no Breve.

A Figura 5.2 mostra alguns dos experimentos realizados no Breve. Em geral, experimentos de Vida Artificial podem consumir algumas semanas de tempo de CPU, sendo completamente desnecessária a visualização do experimento até seu término. Por este motivo o Breve permite iniciar a simulação sem utilizar recursos gráficos, sendo possível executá-la numa estação de trabalho onde não esteja instalado nenhum servidor de janelas ou biblioteca de aceleração gráfica. 
Também é possível a criação de diversas câmeras no ambiente, permitindo a visualização da simulação sob diversos ângulos, simultaneamente. Aplicações desta natureza são especialmente interessantes para o uso em cavernas digitais.

\subsubsection{Interface com Outras Linguagens}

Além da simulação física do ambiente e a visualização 3D, é necessária uma forma prática de escrevermos simulações que exija do experimentador o mínimo possível em termos de código, se preocupando principalmente com o conteúdo da simulação. Nas primeiras versões do Breve a única forma de utilizá-lo era através de uma linguagem chamada Steve, desenvolvida pelo próprio autor (evitando o uso direto de chamadas a funções em $\mathrm{C} / \mathrm{C}++)$. Embora Steve seja de fácil uso e orientada a objetos, requer o aprendizado de uma nova linguagem para uso específico.

Para resolver o problema, atualmente o Breve tem total compatibilidade com Python, permitindo que os experimentos sejam escritos numa linguagem de alto nível e de propósito geral. O suporte a Steve ainda é mantido.

\subsubsection{Simbad}

Um segundo simulador de código aberto, voltado principalmente para experimentos de robótica evolutiva, é o Simbad (HUGUES; BREDECHE, 2006). Assim como o Breve, o Simbad é um ambiente virtual 3D escrito em Java, a mesma linguagem usada para desenvolver experimentos (Figura 5.3). Na versão atual o Simbad permite a adição de alguns tipos de objetos, como obstáculos em forma de paredes, cubos ou arcos. O agente é uma representação dos robôs do tipo Khepera e podem ser criados utilizando alguns tipos de sensores pré-modelados, como infra-vermelho, sonar e colisão. Também é possível, embora com algumas restrições, acoplar uma câmera matricial ou linear, permitindo que o robô perceba o ambiente através de visão. Assim como em Robótica Evolutiva, os atuadores são representados por duas rodas, situadas bi-lateralmente. As rodas podem ser ativadas diretamente aplicando um torque em cada uma delas, ou ainda utilizar uma interface de mais alto nível indicando apenas a velocidade com que se deseja que o robô ande ou vire (caso contrário estes dois comportamentos deveriam ser combinados simultaneamente pela ativação das rodas).

Outra funcionalidade no Simbad é o uso de outras bibliotecas para redes neurais e algoritmos genéticos, tornando o simulador um ambiente completo para experimentos de robótica evolutiva. Entretanto, até a escrita deste trabalho, o Simbad tem recebido pouca 

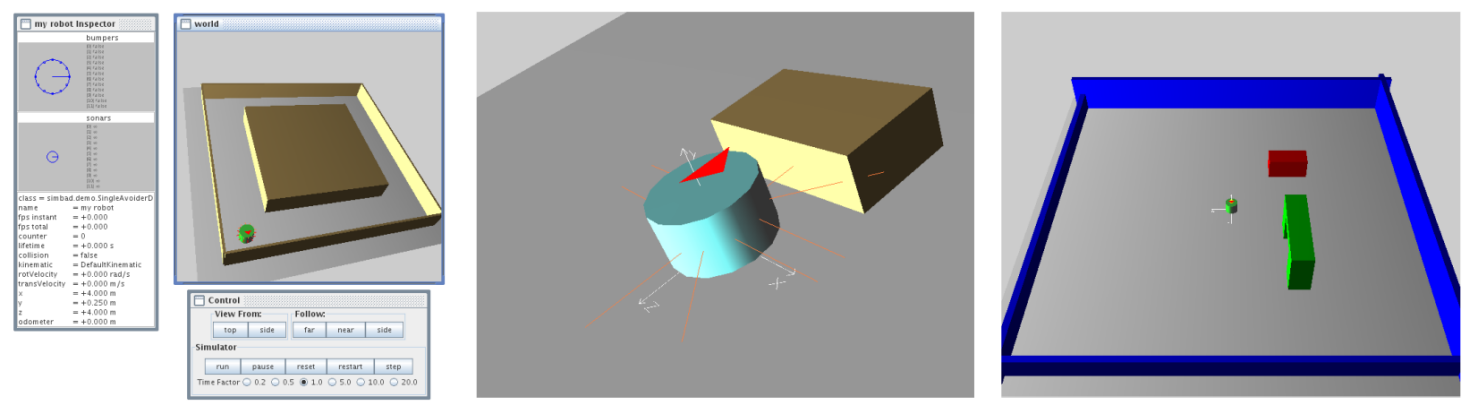

Figura 5.3: Simbad: Ambiente de simulação para robótica evolutiva (HUGUES; BREDECHE, 2006).

atenção e seu desenvolvimento está estagnado. Dentre os motivos, está principalmente a falta de documentação, suporte por parte dos desenvolvedores e poucos recursos disponíveis. Experimentos um pouco mais elaborados exigiriam a mudança do código fonte.

Contudo, por ser escrito em Java, uma vantagem do Simbad é a sua integração com Python através do Jython ${ }^{2}$, uma máquina virtual para interpretar código Python escrita diretamente em Java. Desta forma é possível utilizar outros módulos escritos em Python, aumentando os recursos do simulador. Apesar disto, não há uma vantagem clara em utilizar o Simbad no lugar do Breve.

\subsection{Simulador de Neuroevolução: Projeto NEAT- Python}

A partir dos trabalhos apresentados na seção 4.2, é possível observar que todos desenvolveram e aplicaram um método próprio de neuroevolução e visualização. Embora seja fornecido um número razoável de informações a respeito do seu funcionamento (permitindo possíveis replicações), o algoritmo de neuroevolução em si não é analisado "fora do experimento", isto é, não se sabe como ele se comporta em experimentos genéricos ou como eles se comparam entre si. Além disto, os trabalhos compartilham entre si características genéricas que poderiam ser implementadas num simulador de uso geral como o Breve (KLEIN, 2002), sem a necessidade de escrever do início todo o conjunto de bibliotecas necessárias.

O NEAT, por ter sido extensivamente explorado, poderia servir como base para trabalhos futuros na mesma linha, já que oferece o aparato mínimo necessário para novas

\footnotetext{
${ }^{2}$ Multi-plataforma, disponível livremente em: jython.org
} 
pesquisas. Desde sua primeira publicação em 2002, diversas implementações surgiram. A primeira, do próprio autor, escrita em $\mathrm{C}++$, foi disponibilizada oficialmente e serviu de base para implementações em outras linguagens ${ }^{3}$. Atualmente é possível encontrar projetos individuais do NEAT implementado em Matlab, Delphi, C\# e Java, este último com pelo menos três variações. É notável a aceitação do método pela comunidade de neuroevolução, principalmente em relação a outras técnicas pouco difundidas ou analisadas, geralmente desenvolvidas por um grupo restrito de pesquisadores.

Na proposta inicial deste trabalho foi usada uma implementação escrita em Java por Simmerson (2008). No entanto, ao longo do desenvolvimento percebeu-se que, devido a certas necessidades e propósitos, grande parte do código precisaria ser modificado e reescrito. Diante disto, optou-se por iniciar um projeto de implementação do NEAT em Python. Dentre os motivos estão a possibilidade de integração direta com o Breve e o uso de uma linguagem de programação multiparadigma de alto nível, sintaxe clara e de rápido desenvolvimento. Surgiu então o projeto NEAT-Python ${ }^{4}$ (MIGUEL; SILVA, 2008), de código aberto e disponível sob licença GPLv3, escrito com a colaboração de Carolina Feher da Silva, do Instituto de Ciências Biomédicas da USP. O projeto foi baseado principalmente nas referências (BUCKLAND, 2002; STANLEY; MIIKKULAIEN, 2002; ADAMS, 2005), além da implementação em $\mathrm{C}++$ do próprio autor. Uma das vantagens do NEAT-Python, em relação às demais implementações, está na modularidade e facilidade em estendê-lo para qualquer tipo de experimento, não ficando restrito apenas para trabalhos em Vida Artificial.

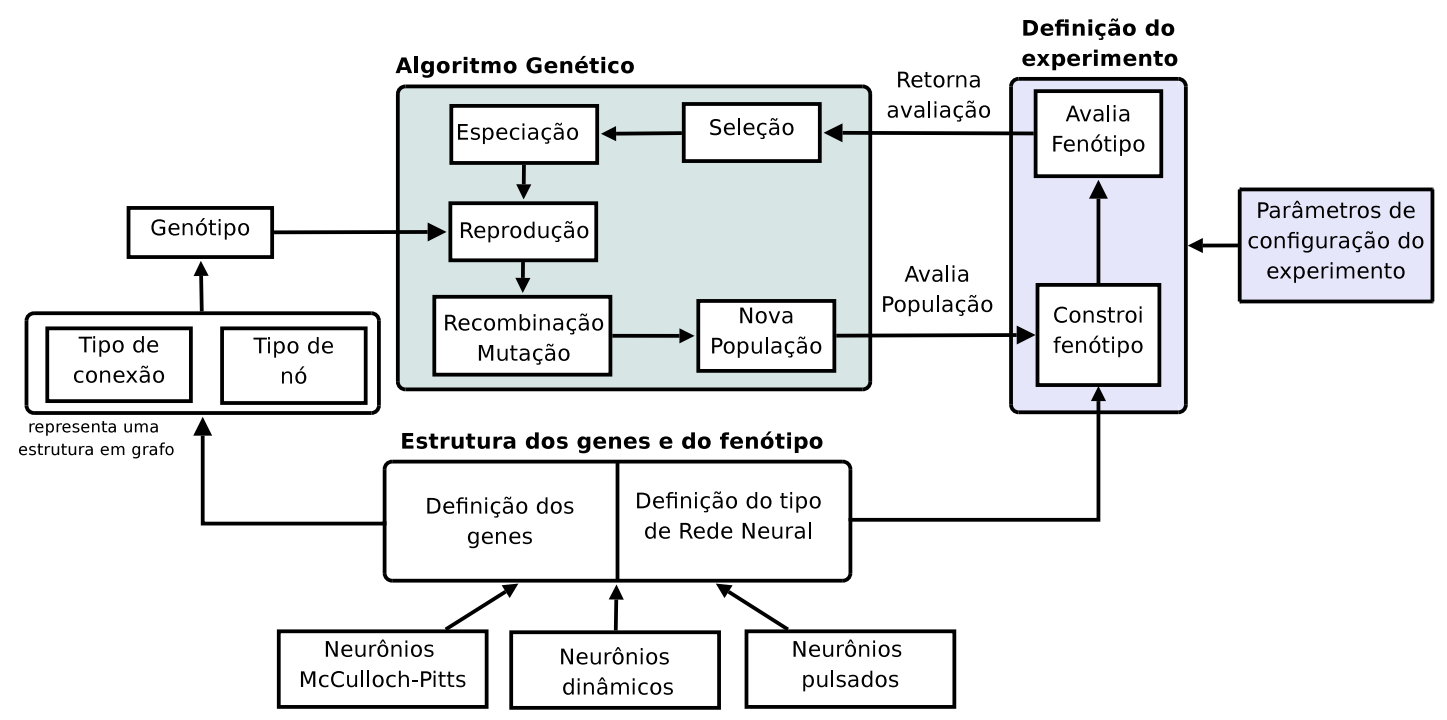

Figura 5.4: Diagrama de blocos para o NEAT-Python.

\footnotetext{
${ }^{3}$ Detalhes em: http://www.cs.ucf.edu/ kstanley

${ }^{4}$ Disponível em: http://code.google.com/p/neat-python
} 
A Figura 5.4 mostra o diagrama das principais componentes do NEAT-Python e como elas se relacionam. Os parâmetros de configuração definem variáveis como o tamanho da população, taxas de mutação, características do fenótipo (rede neural), especiação dentre outros. A descrição de todos os parâmetros é apresentada no Anexo A (p. 104). O bloco para a definição do experimento é onde a função de aptidão é implementada para avaliar a população. No NEAT, o Algoritmo Genético trabalha com estruturas genéricas em formas de grafo, definidas pelo genótipo. Portanto é possível utilizar diversas estruturas diferentes desde que a comunicação (interface) entre os módulos seja mantida. Basicamente, cada experimento é definido por um conjunto de parâmetros e a sua função de aptidão, de forma que a realização de novos experimentos é facilitada pela modularidade do código.

\subsubsection{Módulo de Redes Neurais}

Além do módulo de redes neurais tradicionais (neurônios sigmodais com ativação discreta), a principal contribuição do NEAT-Python, em relação a outros projetos, está no módulo de CTRNNs. Conforme a Figura 5.4, a estrutura dos genes e do fenótipo pode ser escrita num módulo separado e acoplada ao núcleo do código. Dependendo do tipo de modelo usado, como no caso das CTRNNs, é possível reutilizar, através de herança, módulos mais básicos como os neurônios sigmodais. Existe também um módulo para redes neurais pulsadas, implementando os modelos InF (Integrate and Fire (MAAS, 1997)) e de Izhikevich (2003). No entanto, tais modelos não são aplicados neste trabalho.

Assim como os diversos modelos neurais, também é possível implementar e utilizar outras estruturas em grafo que possam se beneficiar da otimização por algoritmos genéticos, como redes Bayesianas.

\subsubsection{Execução Paralela}

Em alguns tipos de simulações com algoritmos genéticos, parte significativa da execução do código é gasta na avaliação da população. O "núcleo" do Algoritmo Genético, que cuida da seleção e reprodução, pode consumir até menos de $5 \%$ do tempo total, dependendo do experimento (STANLEY, 2004). Uma solução imediata seria paralelizar o código responsável pela avaliação dos indivíduos. Diversas propostas de paralelização de AGs existem (NOWOSTAWSKI; POLI, 1999), mas o desempenho de cada algoritmo depende fortemente do tipo de problema que está sendo resolvido.

Neste trabalho alguns experimentos foram realizados utilizando a biblioteca de 
processamento paralelo e distribuído chamada Parallel Python (VANOVSCHI, 2008). Esta mudança não altera a forma com que o NEAT é executado, exceto no momento da avaliação da população. A figura 5.5 mostra o esquema adotado na paralelização.

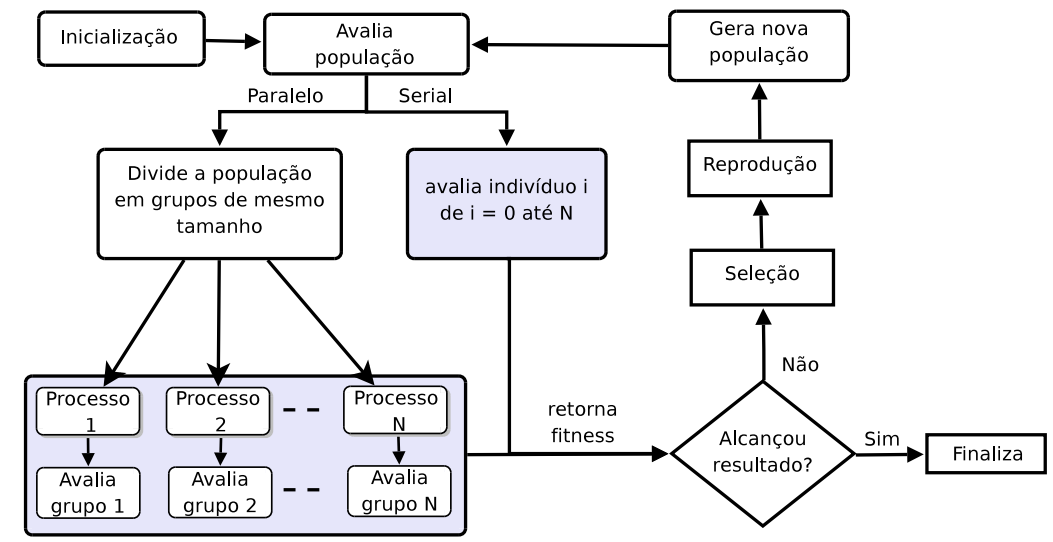

Figura 5.5: Algoritmo Genético Seqüencial e Paralelo.

Cada processador recebe uma única tarefa (processo) e ao finalizar retorna um vetor contendo o valor adaptativo para cada indivíduo daquele grupo. O processador pode ser local (i.e., em máquinas com múltiplos núcleos), distribuído em máquinas conectadas numa rede local (configuração de cluster) ou ainda através da Internet. O grupo de indivíduos, quando enviado para avaliação, é comprimido para economizar na comunicação dos processos. Com este tipo de granularidade, o custo computacional não é significativo e pode melhorar drasticamente simulações em máquinas conectadas por redes de alta latência.

Se o tempo de execução de um único grupo somado ao tempo de comunicação entre o servidor e os processos for menor que a execução do mesmo grupo na versão serial, então a paralelização é vantajosa e a velocidade cresce linearmente com a adição de processadores. Esta conclusão foi obtida empiricamente através de diversos ensaios computacionais.

\subsubsection{Integração com o Breve}

A principal vantagem do NEAT-Python está na integração com o simulador Breve. O tipo de implementação utilizado permite que as bibliotecas do Breve sejam utilizadas a partir do módulo da definição do experimento, isto é, ao avaliar cada indivíduo é necessário carregar o simulador externo que cuidará da criação do ambiente e de como o organismo interage com o mesmo. A Figura 5.6 ilustra o processo. 


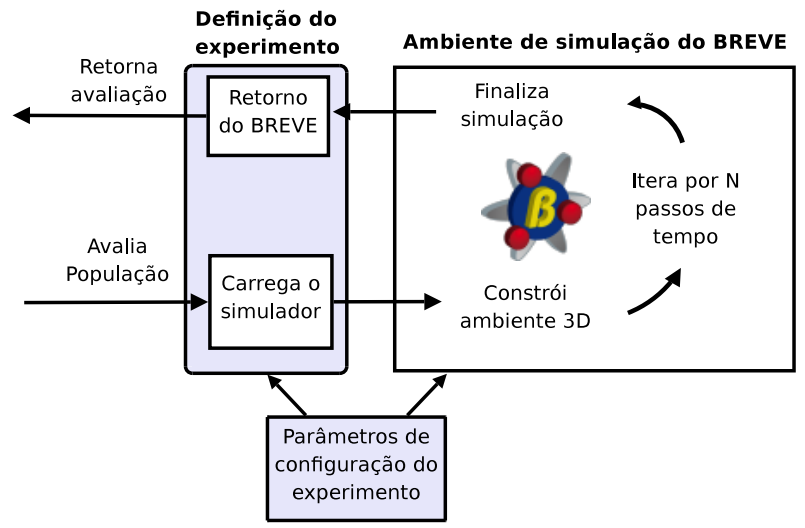

Figura 5.6: A integração do NEAT e Breve é feita na definição do experimento.

\subsection{Observações Finais}

Com a integração do NEAT-Python e do Breve, é evidente que parte dos esforços dos trabalhos anteriores, descritos na seção 4.2, podem ser implementados e reproduzidos a partir desta proposta (MIGUEL; NETTO, 2008). O capítulo seguinte avalia a biblioteca NEAT-Python na solução de problemas clássicos de aprendizado e mostra uma simulação de vida artificial envolvendo um ambiente simples modelado pelo Breve. 


\section{Experimentos}

Este capítulo apresenta a realização de alguns experimentos utilizando o NEAT-Python. O primeiro exemplo ilustra a solução numa típica tarefa de aprendizado supervisionado. O segundo experimento trata da evolução de CTRNNs, integrado ao NEAT, num clássico problema de aprendizado por reforço. Os resultados obtidos motivam sua aplicação em problemas de domínio dinâmico e não-supervisionado, como simulações de Vida Artificial.

\subsection{Ou-Exclusivo}

Para demonstrar o desempenho do NEAT, em particular da implementação NEATPython, a função booleana Ou-Exclusivo (XOR) será resolvida sob diversas situações de configuração, sendo bastante útil para estudar aspectos gerais do comportamento do NEAT. É importante ressaltar que, atualmente, encontrar uma solução para o XOR usando redes neurais é bastante trivial e portanto serve apenas como um simples teste, tradicionalmente aplicado para demonstrar o funcionamento e as diferenças entre diversos métodos de neuroevolução.

\subsubsection{Descrição do Problema}

Como descrito no Capítulo 2, um dos problemas com o Perceptron era o de não ser capaz de aprender a classificar padrões linearmente não-separáveis. Neste contexto, aprendizado é visto simplesmente como a minimização do erro (segundo alguma métrica) na aproximação de uma função. Portanto, funções booleanas tais como OR ou AND podem ser aproximadas por um Perceptron já que são linearmente separáveis (Figura 6.1).

O problema, entretanto, está em como classificar um conjunto de pontos que não podem ser separados, no caso em duas dimensões, por uma reta (Figura 6.2). Talvez o exemplo mais simples que ilustre o problema é dado pela função XOR (ou-exclusivo), onde valores de entrada iguais retornam uma saída "0" (falso) e, caso contrário, "1" 

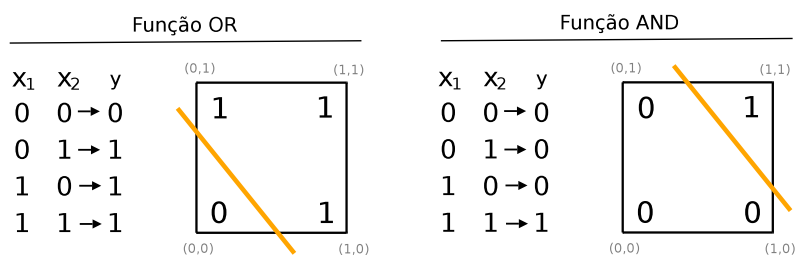

Figura 6.1: Funções booleanas OR e AND, representam conjuntos linearmente separáveis.

(verdadeiro).
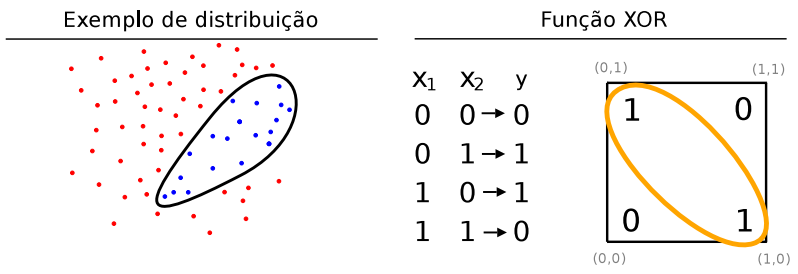

Figura 6.2: Exemplo de conjunto linearmente não-separável (esquerda) e a função XOR.

\subsubsection{Metodologia}

O primeiro passo é definir a função de adaptação, responsável por atribuir valores indicando o desempenho de cada rede neural na solução do XOR. Uma maneira possível é usar o erro médio quadrático, dado por:

$$
E(O, T)=\sqrt{\frac{1}{4} \sum_{i=1}^{4}\left(o_{i}-t_{i}\right)^{2}}
$$

onde $O=\left\{o_{1}, o_{2}, o_{3}, o_{4}\right\}$ representa a resposta real da rede neural para cada padrão de entrada do conjunto de treinamento, cujas respectivas respostas desejadas são $T=$ $\{0,1,1,0\}$. O algoritmo genético seleciona indivíduos (soluções candidatas) em função do seu valor adaptativo, sendo que indivíduos melhores recebem um valor maior. Como nosso objetivo é minimizar a função de erro (de forma que a resposta da rede neural esteja o mais próxima possível do padrão desejado), a cada indivíduo (cromossomo) é atribuído seu valor de aptidão dado por $F_{c}=1-E(O, T)$. Desta forma, quanto mais próximo de 1, melhor será a solução. O problema do XOR pode ser resolvido com apenas um neurônio oculto (KOVACS, 2002), portanto, como conhecemos a solução ótima, podemos efetivamente comparar com a solução obtida pelo NEAT.

O mesmo experimento foi realizado 5000 vezes, utilizando uma população de 150 
indivíduos. Os demais parâmetros do experimento estão definidos na Tabela B.1 do Apêndice B (p. 107). O número de espécies possíveis não foi especificado, permitindo que o algoritmo divida a população da melhor maneira. Para cada espécie $10 \%$ dos indivíduos foram selecionados para reprodução, mas apenas o melhor (com maior valor adaptativo) é mantido para a próxima geração (elitismo).

\subsubsection{Resultados e Discussão}

A Tabela 6.1 mostra os resultados para os casos com elitismo e sem elitismo. Para o primeiro experimento, o NEAT-Python leva, em média 27, 52 gerações (desvio padrão de 16,79) para encontrar uma solução com erro quadrático inferior a 0,1. Neste experimento, foi necessária uma média de 3.903 avaliações de indivíduos até a solução, com um desvio padrão de 2.225. O número máximo de avaliações necessárias para encontrar a solução durante todas as rodadas foi de 11.304 (83 gerações) e o mínimo 1.769 (12 gerações), além disto, a solução ótima foi encontrada em $10 \%$ dos casos, levando a uma média de 3,37 neurônios ocultos por solução, com uma média de 9,68 conexões. O número de avaliações representa melhor o desempenho do algoritmo já que o número de gerações está relacionado ao tamanho da população.

\begin{tabular}{|c|c|c|c|c|c|}
\hline \hline Experimento & & gerações & neurônios & conexões & avaliações \\
\hline \hline \multirow{2}{*}{ Com elitismo } & $\bar{x}$ & 27,52 & 3,37 & 9,68 & 3.903 \\
& $\Delta x$ & 16,79 & 1,91 & 4,12 & 2.225 \\
\hline \hline \multirow{2}{*}{ Sem elitismo } & $\bar{x}$ & 24,38 & 3,14 & 9,31 & 3.733 \\
& $\Delta x$ & 11,70 & 1,25 & 3,06 & 1.759 \\
\hline \hline
\end{tabular}

Tabela 6.1: Resultados para o XOR em duas configurações.

No caso sem elitismo os valores obtidos foram ligeiramente melhores, mas não apresentam significância estatística. É importante notar que o NEAT-Python obteve soluções com um menor número de avaliações em relação a implementação original, reportada por Stanley (2004). A solução foi encontrada em todas as 5.000 rodadas, evidenciando a importância da especiação para evitar mínimos locais. A Figura 6.3 (a) mostra o comportamento das espécies ao longo das gerações para uma rodada particular. Neste caso a solução (não ótima) foi encontrada na geração 14 (eixo-x). No eixo-y temos o tamanho de cada espécie (representada por uma cor única) para cada geração. Note que, logo após a segunda geração, surgem mais duas espécies, reduzindo a quantidade de indivíduos da primeira espécie. Novas espécies podem surgir e mudar de tamanho dinamicamente, em função de seu valor adaptativo médio. Neste exemplo o algoritmo 
encontrou a solução na geração 14. Na Figura 6.3 (b) temos o comportamento para uma segunda rodada, mostrando a evolução do valor adaptativo do melhor indivíduo e a média da população, onde a solução ótima foi atingida na geração 38 .

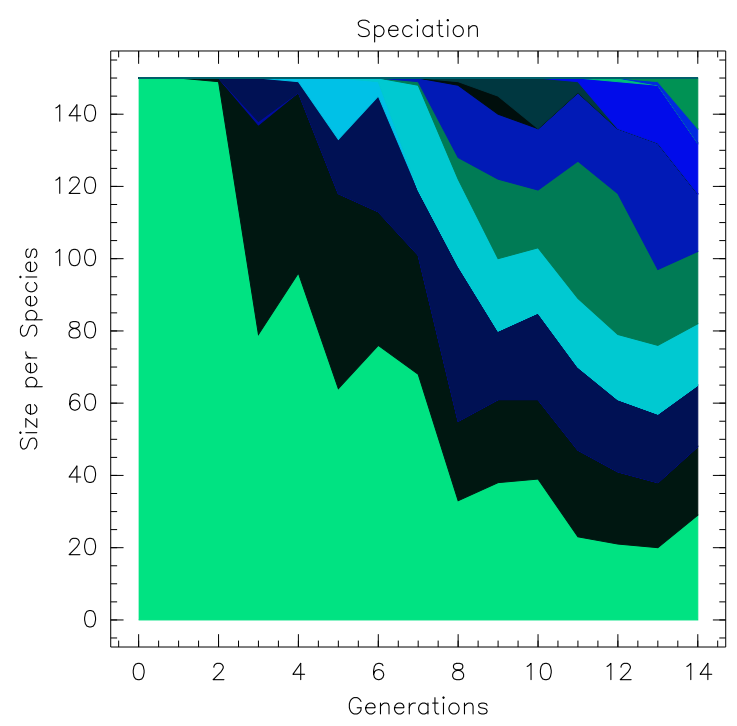

(a)

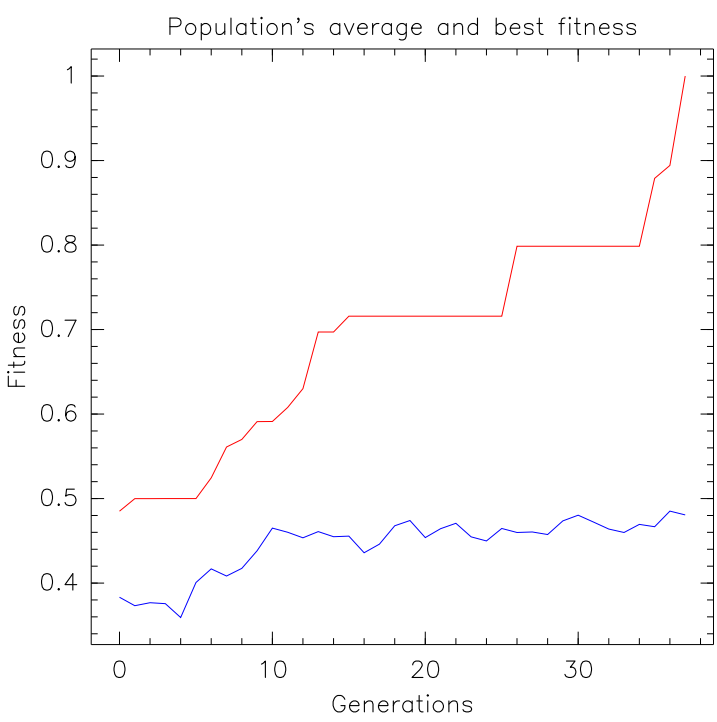

(b)

Figura 6.3: (a) Distribuição de espécies ao longo das gerações e (b) evolução do valor adaptativo do melhor indivíduo e da média da população.

Uma solução típica é apresentada na Figura 6.4, com 2 neurônios ocultos e 7 conexões, ao lado da solução ótima para o problema do XOR. Os neurônios ocultos, além da saída, recebem um bias (não mostrado na figura).

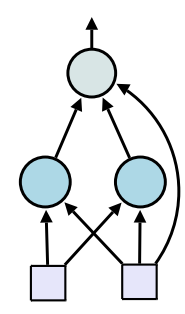

solução típica

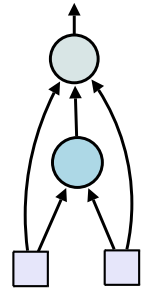

solução ótima

Figura 6.4: Solução típica encontrada pelo NEAT (esquerda), comparada com a topologia ótima (direita).

A solução do XOR através de neuroevolução exemplifica a aplicação de aprendizado supervisionado com o uso de Algoritmos Genéticos. O experimento pode ser facilmente estendido para situações onde o problema de aprendizado seja realmente complexo, como classificação de células cancerígenas, identificação de faces ou impressões digitais. Alguns trabalhos mostram que aprendizado supervisionado através de processos evolutivos podem 
efetivamente apresentar um desempenho superior aos métodos tradicionais (SIDDIQUE; TOKHI, 2001) em alguns casos. Técnicas híbridas também podem tirar proveito iniciando a busca com o NEAT e otimizando o resultado com outro método.

\subsection{Pêndulo Invertido}

Há um grande número de métodos que procuram obter arquiteturas de redes neurais por processos evolutivos. Praticamente cada grupo em cada centro de pesquisa desenvolve e implementa seu próprio método. Embora não exista uma métrica padrão para medir o desempenho entre os diversos métodos ou implementações, há uma tradição na literatura em fazer testes comparativos usando o pêndulo invertido, problema clássico da área de controle (GOMEZ, 2003).

Esta seção descreve experimentos usando a implementação NEAT-Python na solução do problema do duplo pêndulo invertido, comparando com resultados anteriores. Além disso, será demonstrado que o resultado pode ser significativamente melhorado ao utilizarmos redes recorrentes de tempo contínuo (apresentadas na Seção 2.1.5 do Capítulo 2, p. 28). Tais resultados motivam o uso deste tipo de arquitetura para experimentos de Vida Artificial na próxima seção.

\subsubsection{Descrição do Problema}

De forma geral, o problema consiste em equilibrar na posição vertical um, ou mais, pêndulos acoplados a um carro (Figura 6.5). No caso em duas dimensões, o carro é capaz de se mover num único eixo em função da força aplicada a ele e o pêndulo tem movimento angular em torno do ponto onde está fixado sobre o carro (na versão mais simples tem-se apenas um pêndulo).

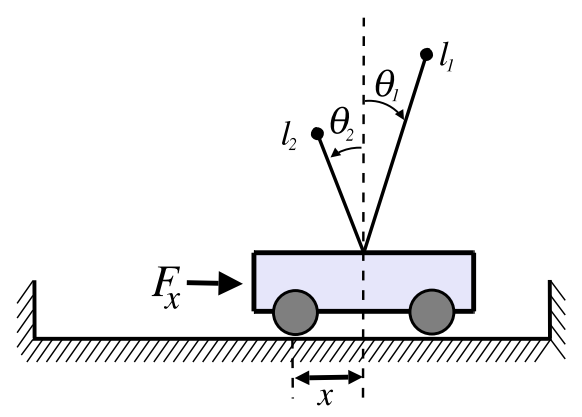

Figura 6.5: Representação para o problema do pêndulo duplo. 
O sistema pode ser descrito por um conjunto de equações diferenciais (WIELAND, 1991), da seguinte forma:

$$
\left\{\begin{array}{l}
\ddot{x}=\frac{F-\mu_{c} \operatorname{sgn}(\dot{x})+\sum_{i=1}^{N} \bar{F}_{i}}{M+\sum_{i=1}^{N} \bar{m}_{i}} \\
\ddot{\theta}_{i}=-\frac{3}{4 l_{i}}\left(\ddot{x} \cos \theta_{i}+g \sin \theta_{i}+\frac{\mu_{p_{i}} \dot{\theta}_{i}}{m_{i} l_{i}}\right)
\end{array}\right.
$$

sendo $N$ o número de pêndulos. A massa e a força do pêndulo $i$ sob o carro é dada respectivamente por:

$$
\left\{\begin{array}{l}
\bar{m}_{i}=m_{i}\left(1-\frac{3}{4} \cos ^{2} \theta_{i}\right) \\
\bar{F}_{i}=m_{i} l_{i} \dot{\theta}_{i}^{2} \sin \theta_{i}+\frac{3}{4} m_{i} \cos \theta_{i}\left(\frac{\mu_{p_{i}} \dot{\theta}_{i}}{m_{i} l_{i}}+g \sin \theta_{i}\right)
\end{array}\right.
$$

Resolver o problema significa encontrar uma forma de manter o pêndulo em equilíbrio apenas aplicando forças nas duas direções possíveis. A versão simplificada do problema, com um único pêndulo, é conhecida por ser facilmente resolvida pelos atuais algoritmos de neuroevolução e, portanto, não oferece qualquer desafio (STANLEY; MIIKKULAIEN, 2002). Na versão com dois pêndulos existem duas abordagens, variando o grau de dificuldade. A primeira opção é fornecer de entrada à rede o estado completo do sistema, definido pelas variáveis: $x$ (posição do carro na pista), $\theta_{1}, \theta_{2}$ (ângulo dos pêndulos 1 e 2 com a vertical), além da velocidade angular de ambos os pêndulos $\left(\dot{\theta}_{1}\right.$ e $\left.\dot{\theta}_{2}\right)$. A segunda versão, com um grau maior de dificuldade, fornece como entrada apenas a posição do carro na pista e o ângulo de inclinação dos dois pêndulos. A Figura 6.6 mostra a árvore de possibilidades para os problemas derivados do pêndulo invertido.

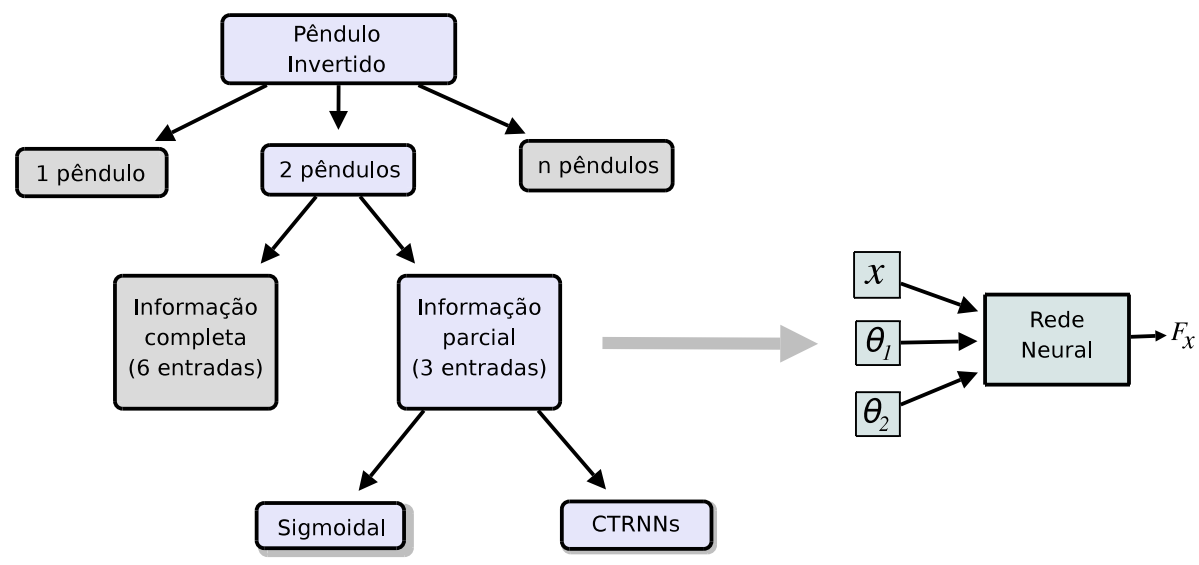

Figura 6.6: As diversas variações para o problema do pêndulo duplo.

Encontrar uma solução sem a rede ter acesso à velocidade angular do pêndulo constitui um problema não-Markoviano (GOMEZ, 2003), já que a rede precisa compensar a falta de informação das derivadas através de conexões recorrentes, ou seja, a solução exige o 
uso de memória de curto prazo para calcular a diferença no ângulo entre dois passos de tempo consecutivos, a fim de fazer uma aproximação de primeira ordem da derivada. Este experimento se concentra apenas no pêndulo duplo sem informação de velocidade angular, denominado DPNV (do inglês, Double Pole Non-Markovian) daqui em frente.

\subsubsection{Metodologia}

Dois tipos de experimentos foram realizados. O objetivo do primeiro foi de confirmar o desempenho do NEAT-Python em relação à implementação original, verificando se os resultados são estatisticamente equivalentes. O propósito do segundo experimento foi testar a hipótese de que, devido à natureza dinâmica das CTRNNs, o problema poderia ser resolvido pelo NEAT com menos avaliações em relação ao uso de redes tradicionais (e portanto, com um desempenho melhor). O método para a evolução de CTRNNs usando o NEAT será referenciado como NEAT-CTRNN (MIGUEL; SILVA; NETTO, 2008).

A simulação funciona da seguinte maneira. Dada uma condição inicial (estado do sistema em $t=0$ ), a cada passo de tempo somente parte do estado é fornecido como entrada para a rede neural: posição do carro na pista $\left(x_{t}\right)$ e o ângulo da vertical do primeiro $\left(\theta_{1}\right)$ e segundo $\left(\theta_{2}\right)$ pêndulo. As entradas são normalizadas em $[-1,1]$ fazendo $\left(\frac{x}{4,8}, \frac{\theta_{1}}{0,52}, \frac{\theta_{2}}{0,52}\right)$. Uma força, proporcional à ativação do neurônio efetor é aplicada no carro, podendo movê-lo para qualquer uma das duas direções do eixo-x. A resposta do sistema é avaliada e os pêndulos são considerados em equilíbrio se as seguintes variáveis permanecerem dentro do intervalo: $-2,4<x<2,4,-36^{\circ}<\theta_{1}<36^{\circ}$ e $-36^{\circ}<\theta_{2}<36^{\circ}$.

Usando a mesma configuração de trabalhos anteriores (GOMEZ, 2003), o sistema de equações diferenciais inicia com os seguintes valores: $x=\theta_{1}=\dot{\theta}_{1}=\dot{\theta}_{2}=0$, e $\theta_{2}=7^{\circ}$. As equações do pêndulo duplo foram integradas numericamente utilizando o método de Runge-Kutta de 4a. ordem com passo $h=0,01$. Além disto, no segundo experimento, as CTRNNs foram resolvidas com o método de Euler com passo $h=0,05$ (BLYNEL; FLOREANO, 2002; STANLEY, 2004). A Tabela 6.2 apresenta o significado e os respectivos valores de cada variável do sistema (Equação 6.2), usados durante a simulação.

\subsubsection{Detalhes da Implementação}

Parte do código para o DPNV (simulação do sistema e a solução das equações) foi obtida da mesma versão escrita em C++ utilizada por Stanley (2004) e Gomez (2003). Isso nos 


\begin{tabular}{|c|l|l|}
\hline \hline Símbolo & Descrição & Valor \\
\hline \hline$x$ & posição do carro & {$[-2,4,2,4] \mathrm{m}$} \\
$\theta_{i}$ & angulo da vertical do pêndulo $i$ & {$[-36,36]^{\circ}$} \\
$F$ & força aplicada ao carro & {$[-10,10] \mathrm{N}$} \\
$l_{i}$ & comprimento do pêndulo $i$ & 0,5 and $0,05 \mathrm{~m}$ \\
$M$ & massa do carro & $1 \mathrm{~kg}$ \\
$m_{i}$ & massa do pêndulo $i$ & 0,1 and $0,01 \mathrm{~kg}$ \\
$\mu_{c}$ & coef. de atrito do carro & $5 \times 10^{-4}$ \\
$\mu_{p}$ & coef. de atrito do pêndulo & $2 \times 10^{-6}$ \\
\hline \hline
\end{tabular}

Tabela 6.2: Parâmetros para o sistema do pêndulo duplo.

garante que os experimentos conduzidos possam ser bastante próximos ${ }^{1}$.

\subsubsection{Configuração do NEAT}

Foi utilizada uma população com 150 indivíduos. Uma espécie (sub-população) foi considerada estagnada se o seu valor adaptativo médio (somatória do valor adaptativo de cada indivíduo dividido pelo tamanho da espécie) não apresentasse aumento após 15 gerações. Nenhum limite sob o número máximo de espécies foi imposto e o limiar de distância entre indivíduos ficou fixo em $\delta=3,5$. Para cada espécie, os indivíduos foram escolhidos para reprodução usando seleção por torneio com tamanho 2. Todos os genes codificando neurônios na primeira geração iniciavam com um bias nulo e com resposta na função de ativação de 4,92 (obtido experimentalmente por Stanley (2004)). Os genes de conexão sináptica foram iniciados aleatoriamente utilizando distribuição Gaussiana com média zero e desvio padrão igual a 1,0. Os demais parâmetros utilizados na configuração do NEAT estão na Tabela B.2 do Apêndice B (p. 108).

\subsubsection{Função de Avaliação}

O método utilizado para avaliar o desempenho da rede neural no DPNV foi elaborado por Gruau (1994) e vem sendo aplicado em praticamente todas as publicações que envolvam neuroevolução. A função de avaliação para este problema penaliza oscilações, isto é, soluções triviais que podem surgir que consistem em empurrar o carro rapidamente em ambas as direções, forçando os pêndulos a permanecerem em equilíbrio (STANLEY; MitKkUlaien, 2002). Para eliminar o oportunismo típico de um Algoritmo Genético, a avaliação é dada pela combinação linear de duas componentes: $f=0,1 f_{1}+0,9 f_{2}$,

\footnotetext{
${ }^{1}$ Usando a própria biblioteca de desenvolvimento do Python, é possível criar extensões em $\mathrm{C} / \mathrm{C}++\mathrm{e}$ usá-las diretamente como módulos em Python.
} 
calculadas da seguinte forma:

$$
\begin{aligned}
& f_{1}=t / 1000 \\
& f_{2}= \begin{cases}0 & \text { if } t<100 \\
\frac{0.75}{\sum_{i=t-100}^{t}\left(\left|x^{i}\right|+\left|\dot{x}^{i}\right|+\left|\theta_{1}^{i}\right|+\left|\dot{\theta}_{1}{ }^{i}\right|\right)} & \text { caso contrário }\end{cases}
\end{aligned}
$$

onde $t$ é o número de passos de tempo em que os pêndulos permanecem equilibrados durante um total de 1000 passos. A segunda componente $\left(f_{2}\right)$ é maximizada quando a velocidade e a posição do carro e do pêndulo maior são minimizadas nos últimos 100 passos de tempo. Ao final de cada geração, a rede neural com melhor desempenho é avaliada novamente num teste de generalização. Este teste serve para dizer o quão robusta é a solução numa simulação estendida, sujeita a diferentes condições iniciais.

O teste é composto de duas partes. Primeiro a rede neural selecionada deve ser capaz de manter os pêndulos equilibrados por pelo menos $100 k$ passos de tempo (com as mesmas condições iniciais descritas anteriormente). Caso a primeira condição seja satisfeita, a rede será avaliada novamente por $1 k$ passos e cada avaliação recebe uma

condição inicial diferente. A cada uma das quatro variáveis $\left(x, \dot{x}, \theta_{1}, \dot{\theta}_{1}\right)$ são atribuídos valores do conjunto $[0,05 ; 0,25 ; 0,5 ; 0,75 ; 0,95]$, resultando em $5^{4}=625$ combinações possíveis para as condições iniciais.

Por fim, a rede neural é considerada uma solução válida se for capaz de generalizar pelo menos 200 vezes no teste de 625 rodadas de $1 k$ passos. O número de vezes que a rede resolve o problema, dividido pelo total de testes, é chamado de coeficiente de generalização (CG). Quanto maior o CG, melhor será a solução. Caso a rede não passe no teste, o algoritmo genético prossegue para a próxima geração.

\subsubsection{Resultados e Discussão}

\subsubsection{Comparação Entre Implementações}

Os primeiros resultados do experimento DPNV utilizando o NEAT foram obtidos por Gomez (2003) e replicados neste trabalho por motivos de verificação. Utilizando a mesma configuração destes experimentos, o NEAT-Python foi comparado com a implementação em C++ de Stanley (2004) na solução do mesmo problema. A Tabela 6.3 mostra os valores médios para 544 rodadas.

O objetivo deste simples experimento foi testar a implementação proposta neste trabalho, mostrando que não há diferença estatística significativa entre as diferentes 


\begin{tabular}{|l|l|l|l|l|}
\hline \hline Método & Avaliações & $\Delta \bar{x}$ & CG & $\Delta \bar{x}$ \\
\hline \hline NEAT C++ & 23.777 & 718,80 & 257 & 1,95 \\
NEAT Python & 24.091 & 519,32 & 272 & 1,98 \\
\hline \hline
\end{tabular}

Tabela 6.3: Comparação entre implementações. CG é o coeficiente de generalização e $\Delta \bar{x}$ o erro padrão da média.

versões $(p>0,72)$, permitindo uma base mais sólida para o experimento da próxima seção.

\subsubsection{Evolução de CTRNNs usando o NEAT}

Os resultados obtidos com o método NEAT-CTRNN foram comparados com o desempenho dos principais métodos existentes e capazes de resolver o DPNV. A Tabela 6.4 mostra o número de avaliações e o coeficiente de generalização para cada método (algumas informações não foram publicadas por alguns autores). As estatísticas para os métodos CE (Cellular Encoding (GRUAU, 1994)), CNE (Conventional NeuroEvolution (GOMEZ; MIIKKULAINEN, 1999)) e ESP (Enforced Subpopulations (GOMEZ; MIIKKULAINEN, 1998)) foram obtidas por (GOMEZ, 2003), enquanto que para o AGE (Analog Genetic Encoding (DÜRR; MATTIUSSI; FLOREANO, 2006)) os valores foram reportados pelo próprio autor. Os dados do NEAT são os mesmos do experimento anterior.

\begin{tabular}{|l|l|l|l|l|}
\hline \hline Método & Avaliações & $\Delta \bar{x}$ & CG & $\Delta \bar{x}$ \\
\hline \hline CE & 840.000 & - & 300 & - \\
CNE & 87.623 & - & - & - \\
ESP & 26.342 & - & - & - \\
AGE & 25.065 & 4.360 & 317 & - \\
NEAT & 23.777 & 718 & 257 & 1,95 \\
NEAT-CTRNN & 4048 & 105 & 274 & 2,11 \\
\hline \hline
\end{tabular}

Tabela 6.4: Resultados para o DPNV para diversos métodos. CG é o coeficiente de generalização e $\Delta \bar{x}$ o erro padrão da média.

A versão utilizando CTRNNs foi capaz de encontrar uma solução em $4.048 \pm 105$ avaliações na média ( $95 \%$ de confiança). Este resultado é significativamente melhor que o NEAT tradicional, o qual encontrou uma solução em $23.777 \pm 718$ avaliações $(p<0,001)$. O coeficiente de generalização (CG) para o NEAT-CTRNN é levemente melhor que o NEAT tradicional $(p<0,001)$. As análises estatísticas foram feitas assumindo que a distribuição dos dados fosse normal (método padrão na literatura para análise de desempenho em neuroevolução). Comparar os resultados obtidos com o NEAT-CTRNN com os métodos CE, CNE, ESP e AGE é estatisticamente difícil já que o desvio padrão 
para a maioria dos métodos em consideração não foram publicados por Gomez (2003) ou Dürr, Mattiussi e Floreano (2006). No entanto, o erro padrão para o número de avaliações reportadas para o AGE sugere fortemente que o NEAT-CTRNN tem um desempenho melhor. Assumindo que os métodos CE, CNE e ESP sejam confiáveis e que não apresentem um desvio padrão relativamente alto, é razoável concluir que o NEATCTRNN também desempenha melhor em relação aos anteriores (MIGUEL; SILVA; NETTO, 2008).

Os resultados obtidos por Dürr, Mattiussi e Floreano (2006) levaram à conclusão de que o AGE foi capaz de encontrar a solução do DPNV em menos avaliações do que o NEAT tradicional. Embora tais resultados tenham sido publicados em 2006, os autores utilizaram dados de (STANLEY; MIIKKULAIEN, 2002), quando o NEAT foi comparado com outros métodos. Investigações mais recentes, devido a Gomez (2003) mostraram que na realidade o NEAT e o AGE desempenham de maneira similar, e este resultado pôde ser confirmado no experimento anterior.

A Figura 6.7 mostra a solução mínima encontrada pelo NEAT-CTRNN (o bias não foi desenhado). Embora não tenha sido fornecido em outros trabalhos, neste experimento a melhor solução para cada rodada tinha em média $0,25 \pm 0,04$ nós ocultos e 4, $77 \pm 0,14$ conexões ativas. A topologia mínima foi encontrada 3 vezes a cada 4 rodadas, e o algoritmo não deixou de achar a solução em nenhuma das 544 vezes.

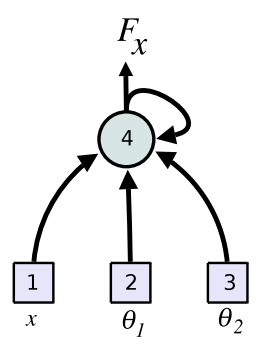

Figura 6.7: Topologia mínima para o DPNV.

A solução mínima para o DPNV exige ao menos uma conexão recorrente. Como no experimento a população inicial consistia apenas de 3 entradas conectadas diretamente à saída, assim que uma conexão recorrente surgisse no neurônio da saída, esta vantagem adaptativa era logo distribuída por toda população nas gerações seguintes. A partir deste ponto, poucas gerações são necessárias para ajustar o conjunto de pesos para encontrar a solução ótima.

A variação para os dois pêndulos é mostrada na Figura 6.8. Quando as condições iniciais do sistema são todas nulas, exceto para $\theta_{2}=7^{\circ}$ (ângulo do pêndulo menor), a 


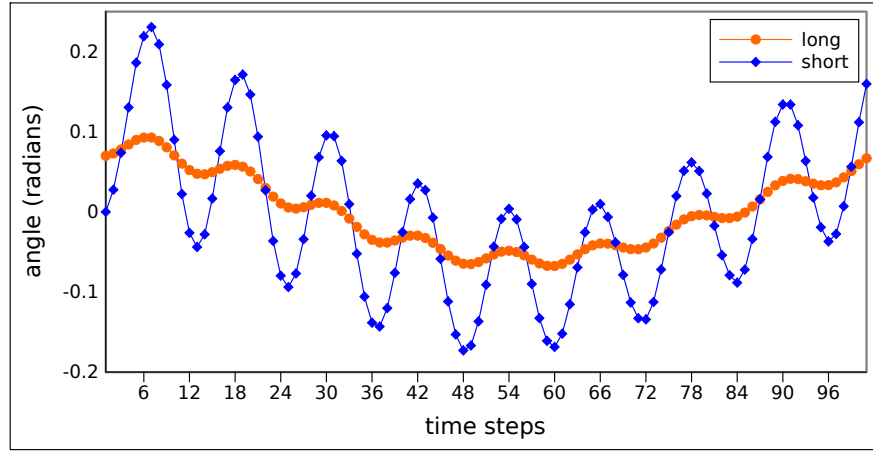

Figura 6.8: Variação do ângulo para os dois pêndulos.

rede neural é capaz de equilibrar os pêndulos dentro de um intervalo menor do que o exigido pelos critérios do experimento.

\subsubsection{Considerações Finais sobre o DPNV}

Diante da habilidade de integrar "estímulos sensoriais" ao longo do tempo, variando continuamente seu estado interno, as CTRNNs mostraram ser capazes de controlar o comportamento de um sistema dinâmico, exigindo menos nós e conexões. Isto explica o menor número de avaliações necessárias quando comparado a outros métodos, já que o algoritmo genético lida com uma dimensão menor no espaço de busca.

Um problema aparente com o DPNV, também notado por Dürr, Mattiussi e Floreano (2006), é a convergência para um mínimo local. Um valor adaptativo maior não significa necessariamente um melhor coeficiente de generalização. Espera-se que o melhor indivíduo seja capaz de obter um desempenho melhor na generalização, mas isto nem sempre acontece. Como o algoritmo genético mantem o melhor indivíduo na próxima geração, isto nos impede de testarmos indivíduos com um valor adaptativo inferior, mas que eventualmente ultrapasse o "melhor" indivíduo no teste de generalização. Uma solução possível é evitar o elitismo, assim a diversidade é sempre mantida e a cada rodada o algoritmo genético avalia um indivíduo diferente. Este comportamento típico demonstra que a função de avaliação proposta por Gruau (1994) apresenta inconsistência entre a capacidade de generalização e o valor obtido pela expressão 6.4 (p. 79).

\subsection{Busca de Alimento}

Talvez a classe de experimentos mais simples em Vida Artificial, envolvendo animats controlados por redes neurais, seja um ambiente onde estão dispostos de certa forma dois 
tipos de objetos: alimento e toxinas. Definida a morfologia (sensores, corpo e efetores) para o animat, a tarefa é encontrar uma arquitetura neural capaz de controlar o sistema motor para maximizar a captura de alimento, minimizando o consumo de toxinas. $\mathrm{O}$ desempenho de cada indivíduo na população é medido usando como parâmetro o total de alimentos e toxinas consumidos durante o tempo de simulação. O objetivo geral do experimento é explorar a adaptação do comportamento através de evolução.

Diferente do trabalho de Sims (1994b), neste tipo de experimento não estamos interessados na evolução morfológica, portanto cada indivíduo é dotado do mesmo aparato sensorial e motor durante a simulação. A única característica que os difere é a topologia e atributos da rede neural.
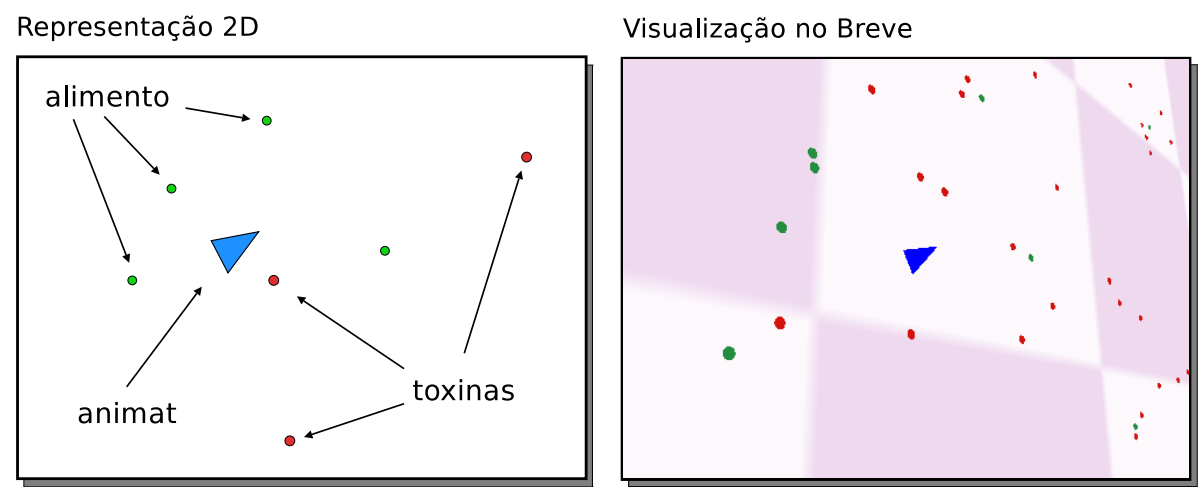

Figura 6.9: Ambiente para busca de alimento e desvio de toxinas.

\subsubsection{Descrição do Problema}

Dado o cenário descrito acima, representado na Figura 6.9, o animat precisa perceber os objetos ao seu redor através de sensores capazes de detectar alimentos e toxinas. A primeira opção seria criar dois tipos de sensores, responsáveis por detectar cada objeto. Mas se considerarmos que o alimento e a toxina podem ser vistos como um único objeto com diferentes níveis de "energia", então podemos usar um único sensor que percebe este nível de "energia" do objeto ao seu redor. Basta convencionar que alimentos têm um nível maior que zero enquanto que toxinas são identificadas por valores negativos. Existem diversas maneiras de se construir este aparato sensorial, e neste experimento foi usada uma estrutura baseada no trabalho de Gomez (2003), como mostra a Figura 6.10.

Neste experimento o animat é dotado de nove sensores que detectam o nível de energia do objeto (alimento ou toxina). Os sensores estão dispostos radialmente e cada um deles responde por uma região definida a cada $45^{\circ}$, com um alcance máximo dado pelo seu raio de percepção $\left(r_{p}\right)$. Se dois ou mais objetos estão no alcance do mesmo sensor, o estímulo 


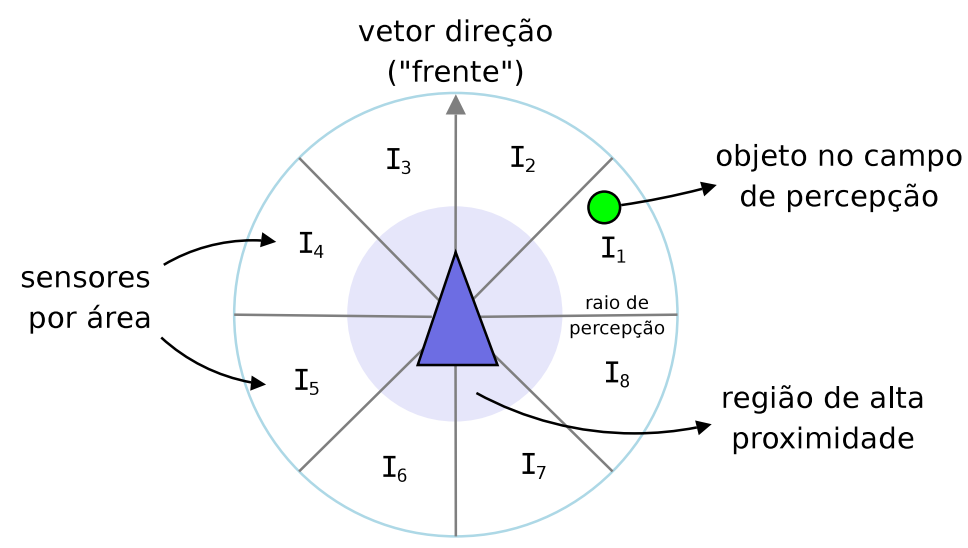

Figura 6.10: Disposição de sensores para decteção de objetos.

recebido será o mesmo, informando apenas que há alguma coisa numa determinada região. Em outra situação, se existir alimento e toxina na mesma região ao mesmo tempo, o estímulo recebido é aleatório, apenas um será detectado. Adicionalmente o animat tem um sensor que detecta objetos muito próximos, geralmente com um alcance $r_{p} / 3$. Este sensor não informa o nível de energia do objeto, ou sua localização aproximada. Ele apenas dispara um valor binário: está próximo ou não. Note que, se o animat detectar apenas um objeto na região $I_{1}$ (como na Figura 6.10), o sensor de proximidade não irá disparar. Mas caso o objeto estivesse suficientemente próximo, além do sensor $I_{1}$, o sensor de proximidade também seria ativado, indicando que há um objeto na região $I_{1}$ "muito" próximo. O sensor de proximidade também pode retornar uma informação ambígua em casos em que existem dois ou mais objetos em áreas diferentes e pelo menos um deles está próximo o suficiente do animat para disparar. Para os experimentos propostos, essa ambigüidade é irrelevante já que a forma com que o ambiente foi modelado tais casos acontecem próximo à captura do objeto. Além disto, é esperado que a rede neural seja capaz de tratar informações conflitantes ou imprecisas.

A capacidade motora do animat é dada por dois atuadores representados na Figura 6.11. A rede neural tem dois neurônios responsáveis pelo movimento motor. Um neurônio controla o grau de inclinação com que o animat irá se virar, enquanto que o outro a velocidade com que ele irá se mover para frente. Por conveniência, a ativação de cada neurônio é dada pela tangente hiperbólica, com a saída no intervalo $[-1,+1]$.

O ângulo máximo absoluto que o animat pode rotacionar é definido pelo atributo $\theta=$ $10^{\circ}$ e portanto a saída do neurônio é mapeada de $[-1,+1]$ para $[-\theta, \theta]$. O mesmo acontece com o segundo atuador, onde a saída é mapeada em $[0,1]$. Deste modo o movimento só acontece na direção em que o animat está apontando. Os sensores externos podem 


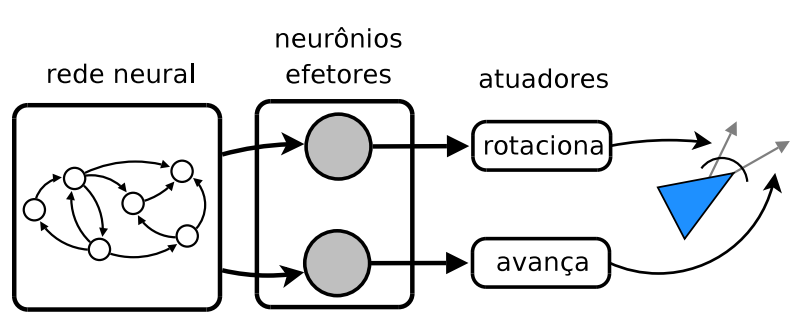

Figura 6.11: Neurônios efetores e atuadores.

detectar o nível de energia de um objeto até 3 unidades de distância do centro do animat, enquanto que o sensor de proximidade capta até 1 unidade de distância. Estes parâmetros podem ser ajustados para cada situação, mas não são alterados durante o experimento.

\subsubsection{Metodologia}

Neste experimento foi usada uma população de 150 indivíduos. A função de aptidão avalia cada indivíduo separadamente num ambiente composto de 200 objetos, sendo que metade é alimento (nível de energia 1,0) e a outra é toxina (nível de energia -0,5). Cada vez que o animat passa pelo objeto, o simulador interpreta como "consumido", removendo-o do ambiente. No mesmo instante o objeto é reposto numa posição aleatória. A cada avaliação o ambiente é iniciado com os objetos distribuídos aleatoriamente numa área de $20 \times 20$ unidades. Desta forma eliminamos a possibilidade do algoritmo genético explorar a simulação "memorizando" a distribuição dos objetos. O valor adaptativo é calculado usando a expressão: $F=A-T$, onde $A$ e $T$ são, respectivamente, o número total de alimentos e toxinas consumidas durante o período de vida. Pode acontecer do valor adaptativo ser menor que zero, neste caso o indivíduo é eliminado.

O animat sempre inicia na mesma posição e sua representação gráfica em forma de triângulo serve como indicativo da posição e orientação (direção em que aponta). A cada passo de tempo o animat recebe informações parciais do ambiente, seu sensores são ativados conforme a configuração da simulação naquele instante de tempo. Em seguida todos os neurônios da rede são ativados paralelamente, uma única vez. Por último, os atuadores são acionados conforme a ativação dos neurônios efetores (Figura 6.12). Este processo se repete em ciclos por 5000 passos de tempo (equivalente a 250 segundos virtuais de simulação no Breve).

O controle do animat foi feito utilizando uma CTRNN, com ativação por tangente hiperbólica. Na primeira geração as redes iniciam sem neurônios ocultos e conexões recorrentes, os sensores são diretamente ligados aos neurônios efetores. As equações foram 


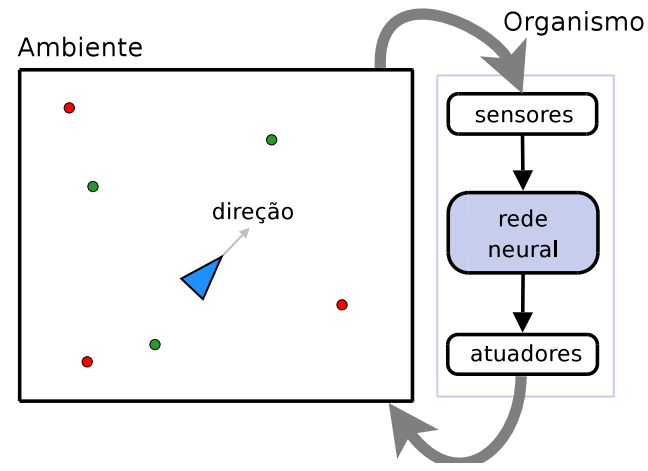

Figura 6.12: Atualização a cada passo de tempo.

resolvidas utilizando o método de Euler com passo $h=0,01$. A constante de tempo dos neurônios foi fixada em $\tau=1$ para evitar instabilidade numérica devido a mutações. Os atributos como ângulo máximo de rotação e velocidade máxima não sofrem alteração durante a simulação. Os demais parâmetros utilizados na configuração do NEAT-Python estão na Tabela B.3 do Apêndice B (p. 109).

\subsubsection{Resultados e Discussão}

Dada a distribuição inicial aleatória dos objetos, é difícil precisar o máximo de alimentos que o animat poderia ingerir durante seu tempo de vida. Como regra geral, vale que quanto maior seu valor adaptativo (i.e., mais alimento e menos toxina consumidos) melhor será o nível de adaptação do animat neste ambiente. Pelo mesmo motivo, o animat que tenha demonstrado uma boa adaptação numa configuração particular do ambiente, não necessariamente terá o mesmo bom desempenho numa configuração diferente, embora, na média, ele deva ser capaz de obter o mesmo desempenho em qualquer ambiente.

A Figura 6.13 (a) mostra o valor adaptativo médio da população ao longo de 50 gerações. Existe um ponto a partir do qual não existe melhora no desempenho (devido à inicialização aleatória). Este valor flutua em torno de um intervalo que representa aproximadamente a média do pior e o melhor caso para qualquer configuração do ambiente, explorado pela população (a linha tracejada mostra uma tendência logarítmica de convergência). Já a evolução do melhor indivíduo exibe um crescimento mais acentuado (Figura 6.13 (b)) mas com certas perturbações, já que a cada geração o cenário se modifica (caso contrário, o valor adaptativo do melhor indivíduo seria monotônico). É possível observar uma tendência linear no aumento do valor adaptativo.

Se fosse utilizado um ambiente estático, i.e, com os objetos dispostos sempre da mesma forma, este aumento seria observado facilmente. No entanto, isto não quer dizer 


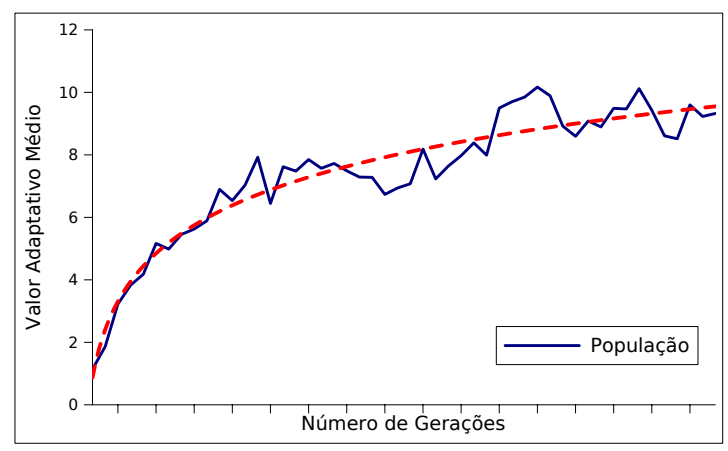

(a)

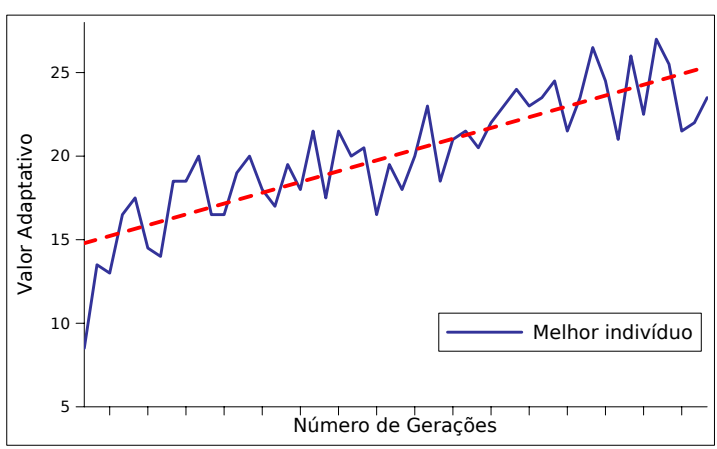

(b)

Figura 6.13: (a) Valor adaptativo médio da população e (b) do melhor indivíduo.

que os animats aprenderiam a classificar os objetos e seguir na direção ideal, significaria apenas que o algoritmo genético explorou a estrutura do ambiente, fazendo com que os pesos sinápticos representassem uma memória de onde estes objetos estão, e não um comportamento de sobrevivência indicando o que fazer sob certas situações.

A principal característica do experimento é mostrar que, mesmo com a definição de uma regra genérica que retorna apenas o desempenho do animat em função do que ele consumiu, o NEAT é capaz de resolver encontrando a topologia e os pesos sinápticos da rede neural responsável pelo controle do animat. O controle, por sua vez, pode ser dividido em duas componentes principais neste experimento: tomar uma decisão motora (qual ângulo virar e a velocidade) e classificar o tipo de objeto detectado pelos sensores (alimento ou toxina). O controle motor é feito com base na decisão tomada a partir da leitura recebida pelo sistema sensorial. A decisão pode fazer com que o animat se vire na direção do alimento para capturá-lo ou "fuja" no sentido contrário ao encontro de toxinas. A arquitetura do melhor indivíduo, obtida pelo NEAT-Python após 50 gerações, é apresentada na Figura 6.14. As conexões ligando os sensores com os neurônios efetores não foram mostradas para simplificar a visualização.

Num ambiente com 100 alimentos e 100 toxinas, a arquitetura obtida é capaz de capturar cerca de 40 objetos, sendo que destes $28,28 \pm 1,03$ são alimentos e 5, $71 \pm 0,32$ são toxinas (valor médio para 100 configurações distintas do ambiente). Estes valores apresentam significância estatística $(p<0,0001)$, mostrando que de fato o animat é capaz de discriminar alimento de toxina, embora em alguns poucos casos não seja possível realizar tal discriminação, ou a ação que leva ao consumo de toxinas. Num cenário diferente, onde o número de toxinas é superior ao número de alimentos, o mesmo animat é capaz de se comportar de forma eficiente. Testando num ambiente com 50 alimentos e 100 toxinas, a mesma significância estatística é obtida, embora o número de 


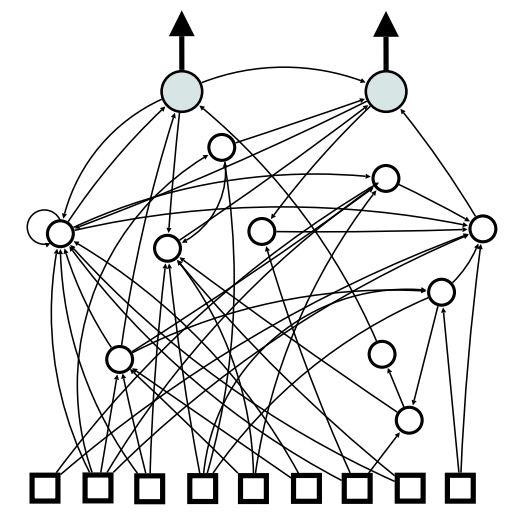

Figura 6.14: Rede neural do animat (as conexões entre os sensores e os neurônios efetores não são mostradas).

alimentos capturados seja menor: $13,64 \pm 0,59$ contra 4,70 $\pm 0,30$ toxinas. Observe que aproximadamente o mesmo número de toxinas é ingerida nos dois tipos de ambientes, o que é facilmente explicável pela quantidade de toxinas distribuídas. Por outro lado, a porcentagem de alimentos capturados é a mesma nas duas situações. No primeiro caso o animat captura aproximadamente $28,28 \%$ de alimentos, enquanto que no segundo experimento, com metade de alimentos, a taxa é de $27,28 \%$.

O caminho percorrido pelo animat num cenário típico é apresentado na Figura 6.15, onde o alimento está em preto e a toxina em cinza claro. Em alguns poucos casos pode ocorrer do alimento estar muito próximo a uma toxina, fazendo com que o indivíduo a consuma ao invés de evitar situações de "perigo".

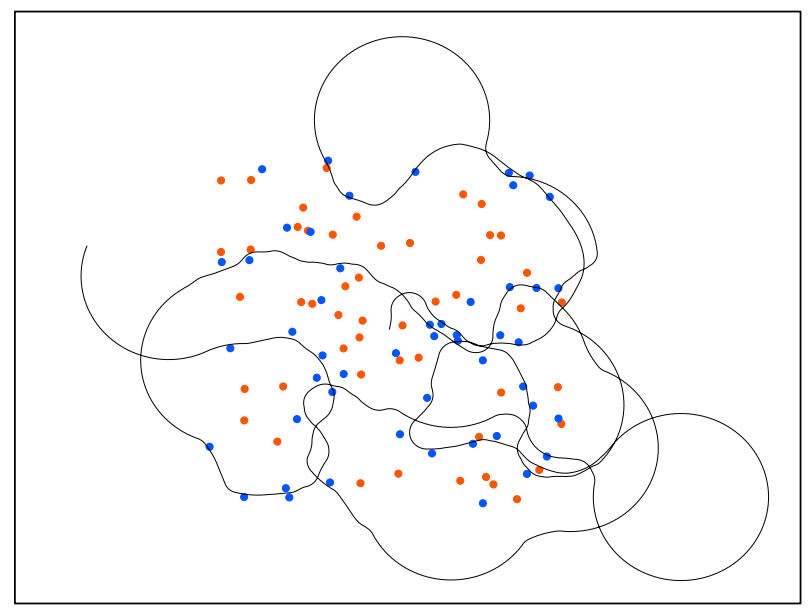

Figura 6.15: Caminho percorrido pelo melhor animat durante seu tempo de vida (resultado após 50 gerações).

O mesmo animat foi colocado num ambiente estruturado onde os objetos estão distribuídos em forma de circunferência, intercalando alimentos e toxinas. O percurso 
é mostrado na Figura 6.16, ao lado do ambiente simulado no Breve.
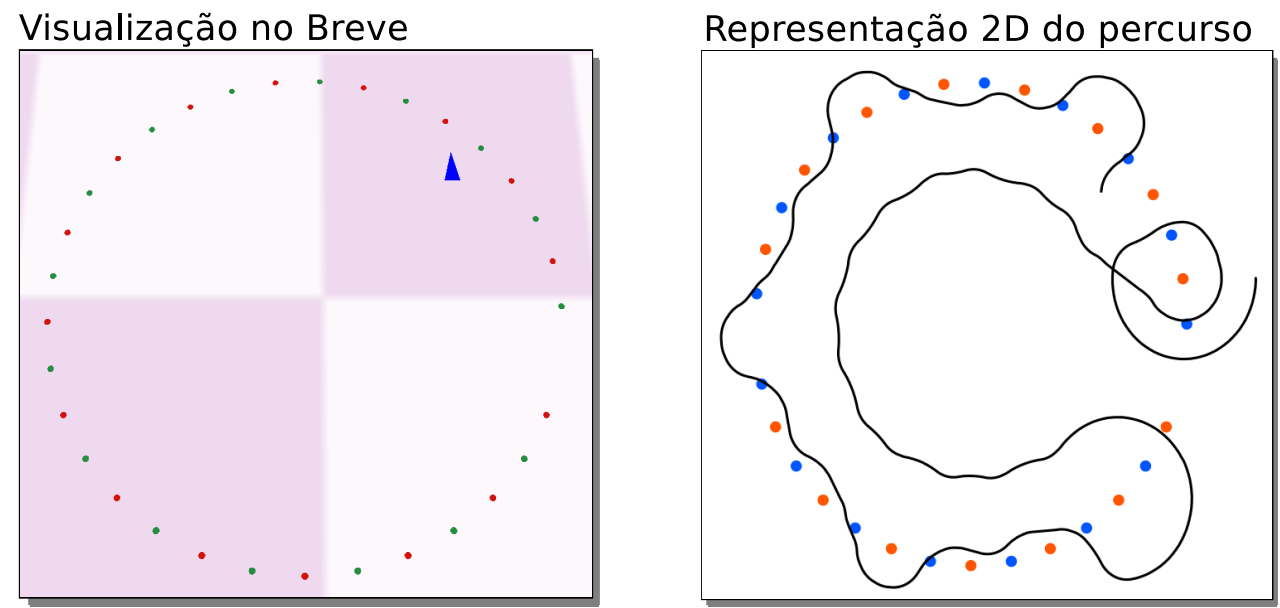

Figura 6.16: Caminho percorrido pelo melhor animat num ambiente estruturado.

Existem pelo menos dois problemas com este tipo de experimento. Primeiro, o método numérico utilizado para integrar as equações que descrevem a CTRNN precisa ser adequado ao tipo de problema que se pretende resolver, isto é, o tempo máximo de vida do animat precisa ser pensado a fim de evitar uma propagação exagerada no erro de integração, o que poderia levar a situações irreais. Neste experimento em particular nenhuma instabilidade foi observada, mas para situações onde seja necessário analisar o comportamento do indivíduo por um longo período de tempo, um método de quarta ordem seria mais apropriado. O segundo ponto diz respeito ao sistema sensório-motor, que limita a capacidade de interação com o ambiente, independente da rede neural obtida para controlá-lo. Neste experimento de busca de alimento, observou-se que, na ausência de objetos detectados pelos sensores, o animat permanece percorrendo em círculo. Duas situações deste tipo podem ser observadas na Figura 6.15, a primeira acontece no lado inferior direito do percurso e a segunda no centro superior. A princípio esperava-se a evolução de comportamento exploratório, com o intuito de maximizar a área percorrida. É possível que o tipo de função de avaliação aplicada não permita este tipo de comportamento, já que o próprio ambiente favorece principalmente a simples busca de alimento, evitando até certo grau o consumo de toxinas.

Em geral, como foi observado, a adaptação do comportamento através da evolução mostra que o animat é capaz de generalizar para ambientes arbitrários. A função de adaptação apenas favorece aqueles que, por algum motivo, foram capazes de consumir mais alimentos do que toxinas, sem ditar como isto deve ser feito. É razoável imaginar que, aumentando a complexidade do ambiente e do sistema sensório-motor do animat, seja possível alcançar níveis cada vez maiores de adaptação e autonomia, desde que o 
"nível de necessidade", assim como discutido por Wilson (1991), esteja bem definido e possa ser mantido acima de um limiar. 


\section{Observações Finais}

Este capítulo apresenta as considerações gerais sobre algumas das limitações e dificuldades encontradas durante o desenvolvimento do trabalho, além das suas principais contribuições na área de Vida Artificial e Neuroevolução. Duas propostas para trabalhos futuros são apresentadas, considerando assuntos que estão em evidência atualmente. Por último, são feitas algumas poucas observações a respeito de métodos de otimização em relação a alternativas inspiradas na biologia.

\subsection{Limitações e Dificuldades}

Inerentes aos métodos de busca evolutiva, no NEAT a quantidade de parâmetros para configurar um experimento pode levar a um segundo problema. Da mesma forma que encontrar uma topologia adequada, determinar um conjunto de parâmetros, como tamanho da população ou a probabilidade de mutação, para configurar um algoritmo como o NEAT, exige a realização de diversos experimentos e a escolha empírica dos parâmetros.

Uma possibilidade é aplicar um meta-AG para encontrar os principais parâmetros. Essa estratégia, onde um primeiro algoritmo genético adapta e controla um segundo, tem sido utilizada para configuração de sistemas que dependam de muitas variáveis (BARCELlOS, 2000). Alguns testes preliminares realizados durante o trabalho mostraram que é viável utilizar meta-AGs em algumas aplicações com o NEAT, embora o custo computacional possa crescer rapidamente deixando de ser uma alternativa viável em alguns casos. Se considerarmos que a cada conjunto de parâmetros escolhido temos associada uma distribuição de probabilidades do comportamento do NEAT, podemos determinar um conjunto que leve a uma distribuição suficientemente genérica para uma classe de problemas, permitindo a aplicação de métodos eficientes para otimização contínua.

Foi observado também que a distribuição estatística inicial dos pesos tem forte 
influência em como o NEAT encontra uma solução. Em experimentos envolvendo o XOR, encontrar o mínimo da função de adaptação (ou função-custo, neste contexto) depende fortemente de como a primeira população é inicializada. Um segundo tipo de comportamento, verificado experimentalmente, mostra a importância de como o operador de mutação paramétrica modifica os pesos sinápticos. Nas primeiras versões do projeto foi utilizada a mutação tradicional, onde o peso atual era alterado por uma pequena perturbação constante. Embora para algumas situações este tipo de mutação seja suficiente, aplicando mutação com distribuição gaussiana com média zero e variância $\sigma$, os resultados foram melhores. Desta forma mutações de pouco impacto são mais freqüentes que mutações mais agressivas, o que pode ajudar a evitar mínimos locais.

Por último, embora o Breve tenha servido aos propósitos deste trabalho, ele traz a desvantagem de não ser adequado para simulações onde o número de indivíduos na população seja alto, tornando o problema computacionalmente intratável ${ }^{1}$. Nestes casos são necessárias outras soluções, como repensar o tipo de experimento de forma que se adeqüe ao simulador utilizado, usar uma versão simplificada para duas dimensões (quando não há necessidade de três dimensões) ou aplicar técnicas de paralelização para algoritmos genéticos.

\subsection{Contribuições}

Este trabalho surgiu com a proposta de se utilizar um método de neuroevolução, conhecido por NEAT, como modelo para a evolução de redes neurais em Vida Artificial, com enfoque em experimentos onde uma população de indivíduos, controlados por redes neurais, interage com um ambiente virtual e se adapta através de evolução. Como ambiente virtual, o Breve é um simulador que oferece as características desejadas, portanto, uma implementação do NEAT que pudesse ser facilmente integrada ao Breve era necessária, já que as existentes não ofereciam este tipo de flexibilidade.

Como resultado, o trabalho culminou no desenvolvimento de uma biblioteca de código aberto para o NEAT, escrita em Python e distribuída sob licença GPL (MIGUEL; SILVA, 2008). Sua principal característica é a modularidade do código e facilidade de extensão, além de permitir a fácil integração com o Breve e, que ao mesmo tempo, possa ser usada em diversos trabalhos, não necessariamente relacionados com o tema de Vida Artificial (MIGUEL; NETTO, 2008).

\footnotetext{
${ }^{1} \mathrm{O}$ número varia conforme o tipo ou estrutura do indivíduo para cada tipo de experimento.
} 
Além da contribuição técnica, o NEAT foi analisado e estendido para adaptar redes neurais de tempo contínuo (CTRNNs). Essa classe de modelos é bastante útil na aplicação de problemas onde o tempo é uma componente importante. Este cenário é muito comum em simulações de Vida Artificial, e até o momento os trabalhos envolvendo CTRNNs utilizavam algoritmos genéticos apenas para adaptar os pesos sinápticos com topologias de redes neurais fixas, o que limita a aplicação onde não se sabe qual é a melhor escolha de topologia a ser usada. Com o NEAT, este problema pôde ser resolvido com boa eficiência, conforme foi demonstrado numa tarefa de controle não-supervisionado (MIGUEL; SILVA; NETTO, 2008).

\subsection{Trabalhos Futuros}

Esta seção descreve algumas possibilidades gerais para trabalhos futuros em neuroevolução, que seguem como um avanço natural a partir do NEAT.

\subsubsection{Codificação Genética Indireta}

Estima-se que, no córtex humano adulto, existam cerca de $10^{11}$ neurônios, cada um fazendo conexão com aproximadamente $10^{4}$ neurônios (um total de $10^{15}$ conexões sinápticas) (CZIKO, 1995). Parte desta massiva rede é construída a partir da informação contida no genoma da espécie e, logo no início de seu desenvolvimento, o número de sinapses é significativamente maior, sendo que muitas são descartadas ao longo da vida do indivíduo num processo onde se acredita ser similar à evolução darwiniana (EDELMAN, 1987). É evidente que representar completamente a estrutura neural a partir de informações contidas nos cromossomos não é viável ou econômico em espécies mais complexas, e o mesmo se estende para todo o fenótipo (organismo). A simetria observada no fenótipo de diversas espécies sugere alguma regra recursiva e compacta de forma que seja possível não especificar cada conexão sináptica, mas uma regra geral que se aplica localmente a cada situação (DAWKINS, 2001).

O NEAT, como foi visto, emprega um mapeamento direto entre o genótipo e o fenótipo, isto é, um mesmo objeto é representado por duas estruturas, convenientes a cada situação. Enquanto que o algoritmo genético manipula apenas o genótipo, representado de maneira com que os operadores genéticos entendam, o fenótipo é uma representação útil para avaliar o desempenho do indivíduo (uma rede neural, neste caso). Outras possibilidades envolvendo codificação indireta existem como modelos 
embriológicos aplicados ao crescimento de redes neurais a partir de simples regras de desenvolvimento (STANLEY; MIIKKULAINEN, 2003). Essa é provavelmente a única abordagem para tratar problemas que envolvam uma complexa arquitetura neural, já que os operadores genéticos não enxergam o fenótipo como um todo (como no caso da codificação direta), mas apenas regras localizadas que interagem para determinar o fenótipo.

\subsubsection{Redes Neurais Pulsadas}

Os modelos neurais utilizados neste trabalho consideram a taxa média de disparos da célula nervosa por intervalo de tempo, cujo comportamento se assemelha à família de funções em forma de S (s-shaped). No entanto, se o interesse está em estudar o comportamento do indivíduo a partir do circuito neural, é importante considerar modelos com maior plausibilidade biológica, onde cada potencial de ação é relevante na transmissão de mensagens (MAAS, 1997). Dentre os modelos de condutância, derivados das equações de Hodgkin-Huxley, destacam-se pela simplicidade computacional, ainda retendo as principais características qualitativas, os modelos Integra-e-dispara (Integrateand-Fire) e de Izhikevich (IZHIKEVICH, 2003).

Atualmente, no campo de Vida Artificial, trabalhos envolvendo redes pulsadas se concentram principalmente em mecanismos de aprendizagem evolucionária para o controle motor e comportamental de indivíduos (FLORIAN, 2006). O NEAT pode ser facilmente estendido para tratar tais modelos, como mostrado na Figura 5.4 (p. 67), embora não seja uma mudança fundamental, pode ajudar na configuração da arquitetura neural assim como nos modelos tradicionais. Uma das dificuldades que surgem diz respeito ao tipo de codificação dos impulsos utilizada para representar estímulos externos contínuos, isto é, como um sensor de toque, por exemplo, envia informações em forma de pulsos para a rede neural e como o controle motor responde aos diferentes tipos de disparos.

Modelos pulsados podem ser usados em situações onde o tempo de resposta seja fundamental para a sobrevivência do indivíduo no ambiente e portanto a precisão entre os intervalos de disparos é essencial para a tomada de decisão e reconhecimento de padrões, como detectar um rosto numa multidão em poucos milisegundos e alterar o comportamento em função do estímulo visual. 


\subsection{Considerações Finais}

Durante os últimos anos, diversos métodos computacionais inspirados na biologia surgiram como proposta para o difícil problema de otimização onde o interesse está em encontrar um conjunto de pesos e a topologia de rede neural adequada para resolver um determinado problema. A dificuldade matemática em tratar estes espaços torna o uso de métodos de busca estocásticos, como os algoritmos genéticos, bastante atraentes neste tipo de situação, onde o conhecimento analítico a respeito do problema a ser resolvido é pouco ou inexistente. Por outro lado, métodos estocásticos são, em geral, difíceis de analisar e extrair resultados que descrevam seu comportamento a longo prazo.

Dada estas limitações, é importante ressaltar que nenhum método de otimização, na média, desempenha melhor que os outros em todos os problemas possíveis (WOLPERT; MACREADY, 1997), o que existem são métodos especializados em otimizar conjuntos restritos de funções, sendo que estes podem se comportar tão bem quanto uma busca aleatória em outros domínios. Em outras palavras, todos os métodos de otimização são equivalentes quando aplicados a todas as possíveis funções. O propósito de utilizar algoritmos genéticos neste trabalho se resume a dois principais motivos:

1. Não há um método analítico conhecido capaz de obter a topologia de rede neural para casos gerais;

2. Em algumas situações o interesse está em simular o processo evolutivo e portanto é necessário replicar suas principais características.

Embora o problema de determinar a topologia da rede seja importante num contexto geral, neste trabalho não se preocupou em tratá-lo do ponto de vista de otimização. A preocupação principal era investigar um método de neuroevolução desenvolvido com base em princípios biológicos com o intuito de utilizá-lo como um modelo da evolução do sistema nervoso, inspirado pelos trabalhos de Yaeger (1994), Sims (1994b), Nolfi e Floreano (2000) e Pfeifer e Scheier (1999), onde a proposta, de maneira geral, é oferecer uma nova metodologia na investigação do comportamento inteligente partindo de regras simples e incrementado conforme a necessidade (abordagem bottom-up).

A solução proposta por Stanley (2004), resultando no NEAT, resolve as principais dificuldades encontradas ao tratar a adaptação de arquiteturas neurais utilizando algoritmos genéticos. Não há, entretanto, um tratamento formal adequado para analisar como este se comporta com as estruturas e operadores utilizados no NEAT. Apesar de o 
método ter demonstrado sucesso na solução de alguns problemas de controle e otimização, seu uso se torna especialmente interessante em problemas de Vida Artificial, onde geralmente os algoritmos genéticos e as redes neurais formam as principais componentes. Além disto, tais aplicações fazem um grande uso de simuladores e, portanto, torna necessário um ambiente no qual os experimentos possam ser realizados. O Breve (KLEIN, 2002) foi escolhido neste contexto por oferecer algumas características desejadas para o tipo de experimento explorado em Vida Artificial, servindo bem para a finalidade proposta no trabalho. 


\section{Referências}

ADAMI, C. Introduction To Artificial Life. New York: Springer-Verlag, 1998.

ADAMS, B. Evolutionary, Developmental Neural Networks for Robust Robotic Behavior. Tese (Doutorado) — Massachusetts Institute of Technology, 2005.

ANGELINE, P. J.; SAUNDERS, G. M.; POLLACK, J. P. An evolutionary algorithm that constructs recurrent neural networks. IEEE Transactions on Neural Networks, v. 5, n. 1, p. 54-65, 1993.

ARBID, M. A. The Handbook of Brain Theory and Neural Networks. 2. ed. Cambridge: MIT Press, 2002.

BAK, P. How Nature Works: The Science of Self-Organized Criticality. [S.l.]:

Springer-Verlag, 1999.

BARCELLOS, J. C. H. Algoritmos genéticos adaptativos: um estudo comparativo. Dissertação (Mestrado) - Universidade de São Paulo, Escola Politénica, São Paulo, Brasil, 2000.

BEER, R. D. Intelligence as Adaptive Behavior: An Experiment in Computational Neuroethology. San Diego, California: Academic Press, Inc, 1990.

. Parameter space structure of continuous-time recurrent neural networks. Neural Computation, MIT Press, Cambridge, MA, USA, v. 18, n. 12, p. 3009-3051, 2006.

BEER, R. D.; GALLAGHER, J. C. Evolving dynamic neural networks for adaptive behaviour. Adaptive Behaviour, v. 1, n. 1, p. 91-122, 1992.

BLYNEL, J.; FLOREANO, D. Levels of dynamics and adaptive behavior in evolutionary neural controllers. In: Proceedings of the seventh international conference on simulation of adaptive behavior on From animals to animats. Cambridge, MA, USA: MIT Press, 2002. p. 272-281.

BRAITENBERG, V. Vehicles: Experiments in Synthetic Psychology. Cambridge, MA: MIT Press, 1984.

BROOKS, R. A robust layered control system for a mobile robot. IEEE Journal of Robotics and Automation, v. 2, n. 1, p. 14-23, 1986.

BUCKLAND, M. AI Techniques for Game Programming. New York: Course Technology PTR, 2002.

CALVIN, W. H. The emergence of intelligence. Scientific American Presents, v. 9, n. 4, p. $44-51,1998$. 
CAMPBELL, M.; HOANE, A. J.; HSU, F.-H. Chips challenging champions: Games, computers and artificial intelligence. Artificial Intelligence, Elsevier Science, Essex, UK, v. 134, n. $1-2$, p. 57-83, 2002.

CAMPOS, A. de; SANTOS, A. M. G. dos; XAVIER, G. F. A consciência como fruto da evolução e do funcionamento do sistema nervoso. Psicologia USP, v. 8, n. 2, 1997.

CHALMERS, D. J. The evolution of learning: An experiment in genetic connectionism. In: TOURETSKY, D. S.; ELMAN, J. L.; SEJNOWSKI, T. J.; HINTON, G. E. (Ed.). Proceedings of the 1990 Connectionist Summer School. [S.1.]: Morgan Kaufmann, 1990. p. $81-90$.

CHANNON, A. D. Passing the alife test: Activity statistics classify evolution in geb as unbounded. In: KELEMEN, J.; SOSIK, P. (Ed.). Advances in Artificial Life: Proceedings of the Sixth European Conference on Artificial Life (ECAL2001). [S.1.]: Springer Verlag, 2001. p. 417-426.

Improving and still passing the alife test: Component-normalised activity statistics classify evolution in geb as unbounded. In: STANDISH, R. K.; BEDAU, M. A.; ABBASS, H. A. (Ed.). Proceedings of Artificial Life VIII. [S.l.]: MIT Press, 2003. p. $173-181$.

CHANNON, A. D.; DAMPER, R. I. Perpetuating evolutionary emergence. In: PFEIFER, R.; BLUMBERG, B.; MEYER, J. A.; WILSON, S. (Ed.). From Animals to Animats V: Proceedings of the Fifth International Conference on Simulation of Adaptive Behavior. Cambridge, MA: MIT Press, 1998. p. 534-539.

CHURCHLAND, P.; SEJNOWSKI, T. J. The Computational Brain. Cambridge, Massachusetts: The MIT Press, 1994.

COLEGRAVE, N. Sex releases the speed limit on evolution. Nature, v. 420, n. 6916, p. 664-666, 2002.

CYBENKO, G. Approximation by superposition of a sigmoidal function. Mathematics of Control, Signal and Systems, v. 2, n. 2-3, p. 303-314, 1989.

CZIKO, G. Without Miracles - Universal Selection Theory and the Second Darwinian Revolution. Cambridge, Massachusetts: The MIT Press, 1995.

DAWKINS, R. O Relojoeiro Cego. [S.l.]: Companhia das Letras, 2001. Tradução: Laura Teixeira Motta.

O Capelão do Diabo. [S.l.]: Companhia das Letras, 2005.

DENNETT, D. C. Darwin's Dangerous Idea: Evolution and the Meanings of Life. Reprint edition. [S.1.]: Simon \& Schuster, 1996.

DORUS, S.; VALLENDER, E. J.; EVANS, P. D.; ANDERSON, J. R.; GILBERT, S. L.; MAHOWALD, M.; WYCKOFF, G. J.; MALCOM, C. M.; LAHN, B. T. Accelerated evolution of nervous system genes in the origin of homo sapiens. Cell, v. 119, n. 7, p. 1027-1040, 2004. 
DRCHAL, J. Evolution of Recurrent Neural Networks. Dissertação (Mestrado) - Faculty of Electrical Engineering, Czech Technical University in Prague, 2006.

DÜRR, P.; MATTIUSSI, C.; FLOREANO, D. A comparison between cellular encoding and direct encoding for genetic neural networks. In: Proceedings of the 9th Conference on Parallel Problem Solving from Nature. Berlin, Germany: Springer-Verlag, 2006. v. 9, p. $671-680$.

DYER, M. G. Toward synthesizing artificial neural networks that exhibit cooperative intelligent behavior: Some open issues in artificial life. Artificial Life, v. 1, n. 1, p. 111-134, 1994.

EDELMAN, G. Neural Darwinism: The Theory Of Neuronal Group Selection. [S.1.]: Basic Books, 1987.

FLOREANO, D.; DÜRR, P.; MATTIUSSI, C. Neuroevolution: from architectures to learning. Evolutionary Intelligence, Springer-Verlag, Berlin, Germany, v. 1, n. 1, p. 47-62, 2008.

FLOREANO, D.; MONDADA. Automatic creation of an autonomous agent: Genetic evolution of a neural network driven robot. In: CLIFF, D.; HUSBANDS, P.; MEYER, J. A.; WILSON, S. (Ed.). From Animals to Animats III. Cambridge, MA: MIT Press, 1994.

FLORIAN, R. V. Biologically inspired neural networks for the control of embodied agents. [S.l.], 2003.

. Spiking neural controllers for pushing objects around. In: AL, N. et (Ed.). From Animals to Animats IX: Proceedings of the Ninth International Conference on the Simulation of Adaptive Behavior. [S.1.]: Berlin: Springer Verlag, 2006. p. 570-581.

FRANKLIN, S. Artificial Minds. 1. ed. Cambridge: MIT Press, 1997.

FRITZSCH, B. Evolution of the ancestral vertebrate brain. In: ARBID, M. A. (Ed.). The Handbook of Brain Theory and Neural Networks. [S.1.]: MIT Press, 2003. p. 426-431.

GERKEY, B.; VAUGHAN, R. T.; HOWARD, A. The player/stage project: Tools for multi-robot and distributed sensor systems. In: Proceedings of the 11th International Conference on Advanced Robotics (ICAR 2003). Coimbra, Portugal: [s.n.], 2003. p. 317-323.

GOMEZ, F. J. Robust non-linear control through neuroevolution. Tese (Doutorado) Department of Computer Sciences, The University of Texas at Austin, Texas, USA, 2003.

GOMEZ, F. J.; MIIKKULAINEN, R. 2D pole-balancing with recurrent evolutionary networks. In: Proceedings of the International Conference on Artificial Neural Networks. Berlin; New York: Springer-Verlag, 1998. p. 425-430.

. Solving non-markovian control tasks with neuroevolution. In: Proceedings of the International Joint Conference on Artificial Intelligence. [S.l.: s.n.], 1999. v. 16, p. $1356-1361$. 
GRUAU, F. Neural Network Synthesis Using Cellular Encoding and the GA. Tese (Doutorado) — l'Ecole Normale Superieure de Lyon, 1994.

GUPTA, J. N. D.; SEXTON, R. S. Comparing backpropagation with a genetic algorithm for neural network training. Omega, v. 27, p. 679-684, 1999.

HARVEY, I.; Di Paolo, E.; WOOD, R.; QUINN, M.; TUCI, E. A. Evolutionary robotics: A new scientific tool for studying cognition. Artificial Life, MIT Press, v. 11, n. 1-2, p. 79-98, 2005.

HARVEY, I.; HUSBANDS, P.; CLIFF, D. Seeing the light: Artificial evolution, real vision. In: CLIFF, D.; HUSBANDS, P.; MEYER, J. A.; WILSON, S. (Ed.). From Animals to Animats III. Cambridge, MA: MIT Press, 1994.

HAYKIN, S. Neural Networks: A Comprehensive Foundation. [S.1.]: Prentice Hall, 1998.

HEBB, D. O. The organization of behavior: A Neuropsychological Theory. New York: Wiley, 1949.

HERNANDEZ, E. D. M. Artificial neural networks based on bifurcating recursive processing elements. 217 p. Tese (Doutorado) — University of Pennsylvania, 1998.

HERNANDEZ, E. D. M. Studying neural networks of bifurcating recursive processing elements - quantitative methods for architecture design and performance analysis. Lecture Notes in Computer Science, v. 2084, p. 546-553, 2001.

HODGKIN, A.; HUXLEY, A. A quantitative description of membrane current and its application to conduction and excitation in nerve. The Journal of Physiology, London, England, v. 117, n. 4, p. 500-544, 1952.

HOLLAND, J. H. Adaptation In Natural And Artificial Systems: an introductory analysis with applications to biology, control, and artificial intelligence. [S.l.]: MIT Press, 2001.

HOPFIELD, J. J. Neural networks and physical systems with emergent collective computational abilities. Proceedings of the National Academy of Sciences, v. 79, p. 2554-2558, 1982.

HOPFIELD, J. J.; TANK, D. W. Computing with neural circuits: A model. Science, v. 233, p. 625-633, 1986.

HUGUES, L.; BREDECHE, N. Simbad : an autonomous robot simulation package for education and research. In: Proceedings of The International Conference on the Simulation of Adaptive Behavior. Rome, Italy: Springer-Verlag, 2006. v. 1, p. 831-842.

HYOETYNIEMI, H. Turing machines are recurrent neural networks. In: ALANDER, J.; HONKELA, T.; JACOBSSON, M. (Ed.). Proceedings of SteP'96-Genes, Nets and Symbols. Helsinki, Finland: Finnish Artificial Intelligence Society, 1996. p. 13-24.

IZHIKEVICH, E. M. Simple model of spiking neurons. Transactions on Neural Networks, v. 14, n. 6, p. 1569-1572, 2003.

Dynamical Systems in Neuroscience: The Geometry of Excitability and Bursting. Cambridge, Massachusetts: The MIT Press, 2007. 
KAELBLING, L. P.; LITTMAN, M. L.; MOORE, A. P. Reinforcement learning: A survey. Journal of Artificial Intelligence Research, v. 4, p. 237-285, 1996.

KLEIN, J. Breve: a 3D simulation environment for the simulation of decentralized systems and artificial life. In: Proceedings of Artificial Life VIII, the 8th International Conference on the Simulation and Synthesis of Living Systems. [S.l.: s.n.], 2002.

KOVACS, Z. L. Redes Neurais Artificiais: fundamentos e aplicações. 3. ed. São Paulo, Brasil: Editora da Livraria da Física, 2002.

MAAS, W. Networks of spiking neurons: the third generation of neural network models. Neural Networks, v. 10, n. 9, p. 1659-1671, 1997.

MAHFOUD, S. W. Niching Methods For Genetic Algorithms. Tese (Doutorado) University of Illinois at Urbana-Champaign, Champaign, IL, USA, 1996.

MCCULLOCH, W. S.; PITTS, W. H. A logical calculus of the ideas immanent in nervous activity. Bulletin of Mathematical Biophysics, n. 5, p. 115-133, 1943.

MICHALEWICZ, Z. Genetic Algorithms + Data Structures = Evolution Programs. [S.1.]: Springer, 1998.

MICONI, T.; CHANNON, A. D. Analysing coevolution among artificial 3D creatures. In: AL., T. et (Ed.). Proceedings of the 7th International Conference on Artificial Evolution (Evolution Artificielle 2005). [S.1.]: Springer, 2006. p. 167-178.

MIGUEL, C. G.; NETTO, M. L. Using a general purpose virtual environment for artificial life simulations. In: X Symposium on Virtual Reality and Augmented Reality. João Pessoa, PB: UFPA, 2008. p. 137-140.

MIGUEL, C. G.; SILVA, C. F. da. A NEAT (NeuroEvolution of Augmenting Topologies) implementation in Python. Acesso em: 20 de maio de 2008. Disponível em: $<$ http://code.google.com/p/neat-python $>$.

MIGUEL, C. G.; SILVA, C. F. da; NETTO, M. L. Structural and parametric evolution of continuous-time recurrent neural networks. In: 10th Brazilian Symposium on Neural Networks. Salvador, Bahia: IEEE, 2008. p. 534-539.

MINSKY; PAPERT. Perceptrons. [S.l.]: MIT Press, Cambridge, 1969.

MITCHELL, M. An Introduction to Genetic Algorithms. [S.l.]: MIT Press, 1996.

NEVES, R. P. O. A.L.I.V.E. Vida Artificial em Ambientes Virtuais: Uma Plataforma Experimental em Realidade Virtual para Estudos dos Seres Vivos e da Dinâmica da Vida. Dissertação (Mestrado) — Escola Politécnica, Universidade de São Paulo, São Paulo, Brasil, 2003.

NEWELL, A.; SHAW, J. C.; SIMON, H. A. Report on a general problem-solving program. In: Proceedings of the International Conference on Information Processing. Paris: [s.n.], 1960. p. 256-264.

NOLFI, S.; FLOREANO, D. Evolutionary Robotics: the Biology, Intelligence, and Technology of Self-Organizing Machines. [S.l.]: MIT Press, 2000. 
NOLFI, S.; PARISI, D. Evolution of artificial neural networks. In: ARBID, M. A. (Ed.). The Handbook of Brain Theory and Neural Networks. [S.1.]: MIT Press, 2003. p. 418-421.

NOWOSTAWSKI, M.; POLI, R. Parallel genetic algorithm taxonomy. In: KnowledgeBased Intelligent Information Engineering Systems. Adelaide, SA, Australia: IEEE, 1999. p. 88-92.

NUSSENZVEIG, H. M. Complexidade e Caos. Rio de Janeiro, Brasil: UFRJ/COPEA, 1999.

O'REILly, R. C.; MUNAKATA, Y. Computational Explorations in Cognitive Neuroscience. Cambridge, Massachusetts: The MIT Press, 2000.

PFEIFER, R.; SCHEIER, C. Understanding Intelligence. Cambridge, Massachusetts: MIT Press, 1999.

RIBAS, G. C. Considerações sobre a evolução filogenética do sistema nervoso, o comportamento e a emergência da consciência. Revista Brasileira de Psiquiatria, v. 28, n. 4, p. 326-338, 2006.

ROJAS, R. Neural Networks: A Systematic Introduction. Berlin: Springer-Verlag, 1996.

ROSENBLATT, F. The perceptron: A probabilistic model for information storage and organization in the brain. Psychological Review, v. 65, n. 6, p. 386-408, 1958.

RUMELHART, D. E.; MCCLELLAND, J. L. Parallel Distributed Processing. [S.l.]: MIT Press, 1987.

SIDDIQUE, M. N. H.; TOKHI, M. O. Training neural networks: backpropagation vs. genetic algorithms. In: IJCNN - International Joint Conference on Neural Networks. [S.l.]: IEEE, 2001. v. 4, p. 2673-2678.

SILVA, C. F. d. Surgimento de atenção seletiva em redes neurais artificiais evoluindo em ambientes com estímulos complexos. Dissertação (Mestrado) — Instituto de Biociências, Universidade de São Paulo, São Paulo, Brasil, 2005.

SIMMERSON, M. NeuroEvolution of Augmenting Topologies For Java. Acesso em: 20 maio de 2008. Disponível em: <http://neat4j.sourceforge.net>.

SIMS, K. Evolving 3D morphology and behavior by competition. In: Artificial Life IV Proceedings. [S.l.: s.n.], 1994. p. 28-39.

$15-22$.

. Evolving virtual creatures. In: SIGGRAPH '94 Proceedings. [S.l.: s.n.], 1994. p.

SMITH, J. Open Dynamics Engine. Acesso em: 20 de maio de 2008. Disponível em: $<$ www.ode.org $>$.

STANLEY, K. Efficient Evolution of Neural Networks Through Complexification. Tese (Doutorado) - The University Of Texas At Austin, Department Of Computer Sciences, Texas, USA, 2004.

STANLEY, K.; MIIKKULAIEN, R. Evolving neural networks through augmenting topologies. Evolutionary Computation, v. 10, p. 99-127, 2002. 
STANLEY, K. O. Compositional pattern producing networks: A novel abstraction of development. Genetic Programming and Evolvable Machines: Special Issue on Developmental Systems, Springer, New York, NY, USA, v. 8, n. 2, p. 131-1620, 2007.

STANLEY, K. O.; BRYANT, B. D.; MIIKKULAINEN, R. Real-time neuroevolution in the nero video game. IEEE Transactions on Evolutionary Computation, v. 9, p. 653-668, 2005 .

STANLEY, K. O.; MIIKKULAINEN, R. Continual coevolution through complexification. In: Proceedings of the Genetic and Evolutionary Computation Conference (GECCO2002). San Francisco, CA: Morgan Kaufmann, 2002.

A taxonomy for artificial embryogeny. Artificial Life, MIT Press, Cambridge, MA, USA, v. 9, n. 2, p. 93-130, 2003.

STEELS, L. The artificial life roots of artificial intelligence. Artificial Life, MIT Press, Cambridge, MA, USA, v. 1, n. 1-2, p. 75-110, 1994.

THUV, O. H. Incrementally Evolving a Dynamic Neural Network for Tactile-Olfactory Insect Navigation. Dissertação (Mestrado) - Norwegian University of Science and Technology, Trondheim, Noruega, 2007.

TRAPPENBERG, T. Fundamentals of Computational Neuroscience. [S.1.]: Oxford University Press, 2002.

VAARIO, J. Artificial life as constructivist AI. Journal of SICE (Japanese Society of Instrument and Control Engineers), v. 33, n. 1, p. 65-71, 1994.

VANOVSCHI, V. Parallel Python. Acesso em: 20 de maio de 2008. Disponível em: $<$ http://www.parallelpython.com/>.

WIELAND, A. P. Evolving neural network controllers for unstable systems. In: Proceedings of the International Joint Conference on Neural Networks. Seattle, WA, USA: IEEE, 1991. v. 2, p. 667-673.

WILSON, S. W. The animat path to AI. In: MEYER, J. A.; WILSON, S. W. (Ed.). From Animals to Animats: Proceedings of the First International Conference on the Simulation of Adaptive Behavior. Cambridge, MA: MIT Press/Bradford Books, 1991. p. $15-21$.

WOLPERT, D. H.; MACREADY, W. G. No free lunch theorems for optimization. IEEE Transactions on Evolutionary Computation, v. 1, n. 1, p. 67-82, 1997.

YAEGER, L. Computational genetics, physiology, metabolism, neural systems, learning, vision, and behavior or polyworld: Life in a new context. In: LANGTON, C. (Ed.). Artificial Life III: Proceedings of the Workshop on Artificial Life. Reading, MA: Addison-Wesley, 1994. v. 17, p. 263-298.

YAMAUCHI, B. M.; BEER, R. D. Sequential behavior and learning in evolved dynamical neural networks. Adaptive Behavior, MIT Press, Cambridge, MA, USA, v. 2, n. 3, p. 219-246, 1994.

YAO, X. A review of evolutionary artificial neural networks. International Journal of Intelligent Systems, v. 4, p. 203-222, 1993. 


\section{Apêndice A - Descrição dos parâmetros usados no NEAT-Python}

Na biblioteca NEAT-Python, cada experimento tem seu próprio arquivo de configuração, definindo todos os parâmetros daquela particular simulação. Os parâmetros são definidos em blocos restritos, estabelecidos em quatro conjuntos: Algoritmo Genético, Fenótipo, Genótipo e Especiação.

\begin{tabular}{llc}
\hline \multicolumn{1}{c}{ Configuração do Algoritmo Genético } & \multicolumn{1}{c}{ Descrição } & Valor Padrão \\
\hline \hline Tamanho da população & Define o tamanho da população & - \\
\hline Adicionar neurônio & $\begin{array}{l}\text { Probabilidade de mutação para } \\
\text { adicionar um novo neurônio }\end{array}$ & 0.03 \\
\hline Adicionar sinapse & $\begin{array}{l}\text { Probabilidade de mutação para } \\
\text { adicionar uma nova conexão entre } \\
\text { dois neurônios }\end{array}$ & 0.05 \\
\hline Mutação do bias & $\begin{array}{l}\text { Probabilidade de mutação do bias } \\
\text { (sensibilidade de disparo do neurônio) }\end{array}$ & 0.2 \\
\hline Intensidade de mutação & $\begin{array}{l}\text { Intensidade máxima na mutação do } \\
\text { bias }\end{array}$ & 0.5 \\
\hline do bias & $\begin{array}{l}\text { Probabilidade de mutação do peso } \\
\text { sináptico }\end{array}$ & 0.9 \\
\hline Intensidade de mutação & $\begin{array}{l}\text { Intensidade máxima na mutação da } \\
\text { sinapse }\end{array}$ & Verdadeiro \\
\hline da sinapse & $\begin{array}{l}\text { Probabilidade de reativar uma } \\
\text { conexão desativada na adição de um } \\
\text { novo neurônio }\end{array}$ & 0.01 \\
\hline Reativar sinapse & $\begin{array}{l}\text { Usado para encerrar a simulação } \\
\text { assim que algum indivíduo alcançar } \\
\text { este valor }\end{array}$ & $\begin{array}{l}\text { Permite rodar o algoritmo genético } \\
\text { usando elitismo ou não }\end{array}$ \\
\hline
\end{tabular}




\begin{tabular}{|c|c|c|}
\hline \multicolumn{3}{|c|}{ Configuração do fenótipo } \\
\hline Parâmetro & Descrição & Valor Padrão \\
\hline Número de entradas & Número total de sensores & - \\
\hline Número de saídas & Número total de neurônios efetores. & - \\
\hline Peso sináptico máximo & Limite superior para o peso sináptico. & +30 \\
\hline Peso sináptico mínimo & Limite inferior para o peso sináptico & -30 \\
\hline Topologia recorrente & $\begin{array}{l}\text { Habilita ou não a evolução de } \\
\text { topologias recorrentes. }\end{array}$ & Verdadeiro \\
\hline Desvio inicial dos pesos & $\begin{array}{l}\text { Desvio padrão da distribuição } \\
\text { Gaussinana na inicialização dos pesos. }\end{array}$ & 0.9 \\
\hline Tipo de ativação & $\begin{array}{l}\text { Define o tipo de ativação de cada } \\
\text { neurônio: exponencial ou tangente } \\
\text { hiperbólica. }\end{array}$ & Exponencial \\
\hline Neurônios ocultos & $\begin{array}{l}\text { Permite inicializar o algoritmo genético } \\
\text { com n nós ocultos. }\end{array}$ & 0 \\
\hline \multicolumn{3}{|c|}{ Configuração do genótipo } \\
\hline Parâmetro & Descrição & Valor Padrão \\
\hline $\begin{array}{l}\text { Limiar de } \\
\text { compatibilidade }\end{array}$ & $\begin{array}{l}\text { Define a distância máxima entre dois } \\
\text { cromossomos }\end{array}$ & 3.5 \\
\hline $\begin{array}{l}\text { Passo para modificar o } \\
\text { limiar de compatibilidade }\end{array}$ & $\begin{array}{l}\text { Valor que controla o passo com que o } \\
\text { limiar de compatibilidade se modifica } \\
\text { dinamicamente para ajustar a } \\
\text { quantidade de espécies }\end{array}$ & 0.0 \\
\hline Coeficiente de excesso & $\begin{array}{l}\text { Controla o peso no excesso de genes } \\
\text { ao calcular a distância }\end{array}$ & 1.0 \\
\hline Coeficiente de disjunção & $\begin{array}{l}\text { Controla o peso nos genes disjuntos } \\
\text { ao calcular a distância }\end{array}$ & 1.0 \\
\hline Coeficiente de sinapse & $\begin{array}{l}\text { Controla o peso da média das sinapses } \\
\text { dos genes homólogos }\end{array}$ & 0.4 \\
\hline
\end{tabular}




\begin{tabular}{|c|c|c|}
\hline \multicolumn{3}{|c|}{ Configuração da Especiação } \\
\hline Parâmetro & Descrição & Valor Padrão \\
\hline $\begin{array}{l}\text { Número desejado de } \\
\text { espécies }\end{array}$ & $\begin{array}{l}\text { Define o número desejado de } \\
\text { espécies (quando o passo para } \\
\text { modificar o limiar é positivo) }\end{array}$ & - \\
\hline Porcentagem de seleção & $\begin{array}{l}\text { Porcentagem dos melhores } \\
\text { indivíduos selecionados para } \\
\text { reprodução }\end{array}$ & $20.00 \%$ \\
\hline $\begin{array}{l}\text { Limiar de idade para } \\
\text { penalização }\end{array}$ & $\begin{array}{l}\text { Idade a partir da qual a espécie é } \\
\text { considerada antiga e passa a } \\
\text { produzir menos indivíduos }\end{array}$ & 30 \\
\hline Valor da penalização & $\begin{array}{l}\text { Porcentagem de redução na } \\
\text { produção de novos indivíduos }\end{array}$ & $20.00 \%$ \\
\hline $\begin{array}{l}\text { Limiar de idade para } \\
\text { incentivo }\end{array}$ & $\begin{array}{l}\text { Idade até onde a espécie é } \\
\text { considerada nova e recebe um } \\
\text { "incentivo" para produzir novos } \\
\text { indivíduos }\end{array}$ & 10 \\
\hline Taxa de incentivo & $\begin{array}{l}\text { Porcentagem de novos indivíduos } \\
\text { adicionados por espécie jovem }\end{array}$ & $20.00 \%$ \\
\hline $\begin{array}{l}\text { Idade para estagnação } \\
\text { máxima }\end{array}$ & $\begin{array}{l}\text { A espécie é removida caso seu } \\
\text { valor adaptativo médio não } \\
\text { apresente aumento nas últimas } n \\
\text { gerações }\end{array}$ & 15 \\
\hline
\end{tabular}




\section{Apêndice B - Configuração dos experimentos}

\begin{tabular}{|c|c|}
\hline Parâmetro & Valor \\
\hline \multicolumn{2}{|l|}{ Configuração do Fenótipo } \\
\hline Número de entradas & 2 \\
\hline Número de saídas & 1 \\
\hline Peso sináptico máximo & +30 \\
\hline Peso sináptico mínimo & -30 \\
\hline Topologia recorrente & Não \\
\hline Desvio inicial dos pesos & 0,9 \\
\hline \multicolumn{2}{|l|}{ Configuração do AG } \\
\hline Tamanho da população & 150 \\
\hline Adicionar neurônio & 0,05 \\
\hline Adicionar sinapse & 0,03 \\
\hline Mutação do bias & 0,2 \\
\hline Intensidade de mutação do bias & 0,5 \\
\hline Mutação da sinapse & 0,8 \\
\hline Intensidade de mutação da sinapse & 1,5 \\
\hline Reativar sinapse & 0,05 \\
\hline \multicolumn{2}{|l|}{ Especiação } \\
\hline Limiar de compatibilidade & 3,0 \\
\hline Coeficiente de excesso $\left(c_{1}\right)$ & 1,0 \\
\hline Coeficiente de disjunção $\left(c_{2}\right)$ & 1,0 \\
\hline Coeficiente de sinapse $\left(c_{3}\right)$ & 2,0 \\
\hline
\end{tabular}

Tabela B.1: Principais parâmetros de configuração para o experimento do XOR (Seção 6.1, p. 71). 


\begin{tabular}{|c|c|}
\hline Parâmetro & Valor \\
\hline \multicolumn{2}{|l|}{ Configuração do Fenótipo } \\
\hline Número de entradas & 6 \\
\hline Número de saídas & 1 \\
\hline Peso sináptico máximo & +30 \\
\hline Peso sináptico mínimo & -30 \\
\hline Topologia recorrente & Sim \\
\hline Desvio inicial dos pesos & 2,0 \\
\hline \multicolumn{2}{|l|}{ Configuração do AG } \\
\hline Tamanho da população & 150 \\
\hline Adicionar neurônio & 0,01 \\
\hline Adicionar sinapse & 0,03 \\
\hline Mutação do bias & 0,20 \\
\hline Intensidade de mutação do bias & 0,50 \\
\hline Mutação da sinapse & 0,80 \\
\hline Intensidade de mutação da sinapse & 1,80 \\
\hline Reativar sinapse & 0,05 \\
\hline \multicolumn{2}{|l|}{ Especiação } \\
\hline Limiar de compatibilidade & 5,5 \\
\hline Coeficiente de excesso $\left(c_{1}\right)$ & 1,0 \\
\hline Coeficiente de disjunção $\left(c_{2}\right)$ & 1,0 \\
\hline Coeficiente de sinapse $\left(c_{3}\right)$ & 2,0 \\
\hline
\end{tabular}

Tabela B.2: Principais parâmetros de configuração para o experimento DPNV (Seção 6.2, p. 75). 


\begin{tabular}{|c|c|}
\hline Parâmetro & Valor \\
\hline \multicolumn{2}{|l|}{ Configuração do Fenótipo } \\
\hline Número de entradas & 9 \\
\hline Número de saídas & 2 \\
\hline Peso sináptico máximo & +30 \\
\hline Peso sináptico mínimo & -30 \\
\hline Topologia recorrente & Sim \\
\hline Desvio inicial dos pesos & 3,0 \\
\hline \multicolumn{2}{|l|}{ Configuração do AG } \\
\hline Tamanho da população & 150 \\
\hline Adicionar neurônio & 0,08 \\
\hline Adicionar sinapse & 0,02 \\
\hline Mutação do bias & 0,40 \\
\hline Intensidade de mutação do bias & 0,25 \\
\hline Mutação da sinapse & 0,95 \\
\hline Intensidade de mutação da sinapse & 1,50 \\
\hline Reativar sinapse & 0,10 \\
\hline \multicolumn{2}{|l|}{ Especiação } \\
\hline Limiar de compatibilidade & 5,0 \\
\hline Coeficiente de excesso $\left(c_{1}\right)$ & 1,0 \\
\hline Coeficiente de disjunção $\left(c_{2}\right)$ & 1,0 \\
\hline Coeficiente de sinapse $\left(c_{3}\right)$ & 0,4 \\
\hline
\end{tabular}

Tabela B.3: Principais parâmetros de configuração para o experimento de Busca de Alimento (Seção 6.3, p. 82). 